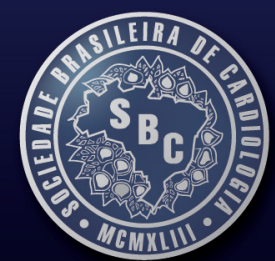

www.cardiol.br

Arquivos Brasileiros de Cardiologia

www.arquivosonline.com.br

Sociedade Brasileira de Cardiologia • ISSN-0066-782X • Volume 100, No 1, Supl.3, Janeiro 2013

\title{
I Diretriz sobre o Consumo de Gorduras e Saúde Cardiovascular
}




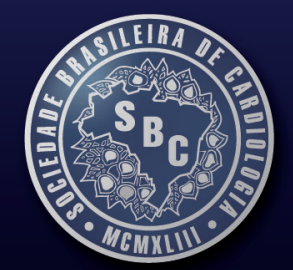

Arquivos Brasileiros de

www.cardiol.br

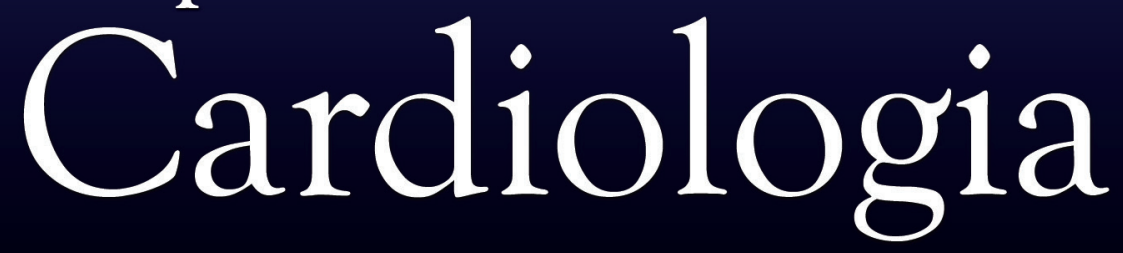

\section{Diretriz sobre o Consumo de Gorduras e Saúde Cardiovascular}

\section{Autores da Diretriz:}

Santos RD, Gagliardi ACM, Xavier HT, Magnoni CD, Cassani R, Lottenberg AMP, Casella Filho A, Araújo DB, Cesena FY, Alves RJ, Fenelon G, Nishioka SAD, Faludi AA, Geloneze B, Scherr C, Kovacs C, Tomazzela C, Carla C, Barrera-Arellano D, Cintra D, Quintão E, Nakandakare ER, Fonseca FAH, Pimentel I, Santos JE, Bertolami MC, Rogero M, Izar MCO, Nakasato M, Damasceno NRT, Maranhão R, Cassani RSL, Perim R, Ramos S 


\section{www.cardiol.br}

\section{Arquivos Brasileiros de Cardiologia}

\section{Diretor Científico}

Luiz Alberto Piva e Mattos

\section{Editor-Chefe}

Luiz Felipe P. Moreira

\section{Editores Associados}

\section{Cardiologia Clínica}

José Augusto Barreto-Filho

Cardiologia Cirúrgica

Paulo Roberto B. Evora

\author{
Cardiologia Intervencionista \\ Pedro A. Lemos
}

Cardiologia Pediátrica/Congênitas

Antonio Augusto Lopes

Arritmias/Marcapasso

Mauricio Scanavacca

Métodos Diagnósticos Não-Invasivos

Carlos E. Rochitte

Pesquisa Básica ou Experimental

Leonardo A. M. Zornoff

\author{
Epidemiologia/Estatística \\ Lucia Campos Pellanda
}

\section{Hipertensão Arterial}

Paulo Cesar B. V. Jardim

\section{Ergometria, Exercício e Reabilitação Cardíaca \\ Ricardo Stein}

Primeiro Editor (1948-1953)

+ Jairo Ramos

\section{Conselho Editorial}

\section{Brasil}

Adib D. Jatene (SP)

Alexandre A. C. Abizaid (SP)

Alfredo José Mansur (SP)

Álvaro Avezum (SP)

Amanda G. M. R. Sousa (SP)

André Labrunie (PR)

Andrei Sposito (DF)

Angelo A. V. de Paola (SP)

Antonio Augusto Barbosa Lopes (SP)

Antonio Carlos C. Carvalho (SP)

Antônio Carlos Palandri Chagas (SP)

Antonio Carlos Pereira Barretto (SP)

Antonio Cláudio L. Nóbrega (RJ)

Antonio de Padua Mansur (SP)

Ari Timerman (SP)

Armênio Costa Guimarães (BA)

Ayrton Klier Péres (DF)

Ayrton Pires Brandão (RJ)

Barbara M. lanni (SP)

Beatriz Matsubara (SP)

Braulio Luna Filho (SP)

Brivaldo Markman Filho (PE)

Bruce B. Duncan (RS)

Bruno Caramelli (SP)

Carisi A. Polanczyk (RS)

Carlos Alberto Pastore (SP)

Carlos Eduardo Negrão (SP)

Carlos Eduardo Rochitte (SP)

Carlos Eduardo Suaide Silva (SP)

Carlos Vicente Serrano Júnior (SP)

Celso Amodeo (SP)

Charles Mady (SP)

Claudio Gil Soares de Araujo (RJ)

Cleonice Carvalho C. Mota (MG)

Dalton Valentim Vassallo (ES)

Décio Mion Jr (SP)

Denilson Campos de Albuquerque (RJ)

Dikran Armaganijan (SP)

Djair Brindeiro Filho (PE)

Domingo M. Braile (SP)

Edmar Atik (SP)

Edson Stefanini (SP)

Elias Knobel (SP)

Eliudem Galvão Lima (ES)

Emilio Hideyuki Moriguchi (RS)

Enio Buffolo (SP)

\section{Eulógio E. Martinez Fo (SP)}

Evandro Tinoco Mesquita (RJ)

Expedito E. Ribeiro da Silva (SP)

Fábio Sândoli de Brito Jr. (SP)

Fábio Vilas-Boas (BA)

Fernando A. P. Morcerf (RJ)

Fernando Bacal (SP)

Flávio D. Fuchs (RS)

Francisco Antonio Helfenstein Fonseca (SP)

Francisco Laurindo (SP)

Francisco Manes Albanesi Fo (RJ)

Gilmar Reis (MG)

Gilson Soares Feitosa (BA)

Ínes Lessa (BA)

Iran Castro (RS)

Ivan G. Maia (RJ)

Ivo Nesralla (RS)

Jarbas Jakson Dinkhuysen (SP)

João Pimenta (SP)

Jorge Ilha Guimarães (RS)

Jorge Pinto Ribeiro (RS)

José A. Marin-Neto (SP)

José Antonio Franchini Ramires (SP)

José Augusto Soares Barreto Filho (SE)

José Carlos Nicolau (SP)

José Geraldo de Castro Amino (RJ)

José Lázaro de Andrade (SP)

losé Péricles Esteves (BA)

José Teles Mendonça (SE)

Leopoldo Soares Piegas (SP)

Luís Eduardo Rohde (RS)

Luiz A. Machado César (SP)

Luiz Alberto Piva e Mattos (SP)

Lurildo Saraiva (PE)

Marcelo C. Bertolami (SP)

Marcia Melo Barbosa (MG)

Marco Antônio Mota Gomes (AL)

Marcus V. Bolívar Malachias (MG)

Maria Cecilia Solimene (SP)

Mario S. S. de Azeredo Coutinho (SC)

Maurício I. Scanavacca (SP)

Mauricio Wajngarten (SP)

Max Grinberg (SP)

Michel Batlouni (SP)

Nabil Ghorayeb (SP)

Nadine O. Clausell (RS)

Nelson Souza e Silva (RJ)
Orlando Campos Filho (SP)

Otávio Rizzi Coelho (SP)

Otoni Moreira Gomes (MG)

Paulo A. Lotufo (SP)

Paulo Cesar B. V. Jardim (GO)

Paulo J. F. Tucci (SP)

Paulo J. Moffa (SP)

Paulo R. A. Caramori (RS)

Paulo R. F. Rossi (PR)

Paulo Roberto S. Brofman (PR)

Paulo Zielinsky (RS)

Protásio Lemos da Luz (SP)

Renato A. K. Kalil (RS)

Roberto A. Franken (SP)

Roberto Bassan (RJ)

Ronaldo da Rocha Loures Bueno (PR)

Sandra da Silva Mattos (PE)

Sergio Almeida de Oliveira (SP)

Sérgio Emanuel Kaiser (RJ)

Sergio G. Rassi (GO)

Sérgio Salles Xavier (RJ)

Sergio Timerman (SP)

Silvia H. G. Lage (SP)

Valmir Fontes (SP)

Vera D. Aiello (SP)

Walkiria S. Avila (SP)

William Azem Chalela (SP)

Wilson A. Oliveira Jr (PE)

Wilson Mathias Jr (SP)

\section{Exterior}

Adelino F. Leite-Moreira (Portugal)

Alan Maisel (Estados Unidos)

Aldo P. Maggioni (Itália)

Cândida Fonseca (Portugal)

Fausto Pinto (Portugal)

Hugo Grancelli (Argentina)

James de Lemos (Estados Unidos)

João A. Lima (Estados Unidos)

John G. F. Cleland (Inglaterra)

Maria Pilar Tornos (Espanha)

Pedro Brugada (Bélgica)

Peter A. McCullough (Estados Unidos)

Peter Libby (Estados Unidos)

Piero Anversa (Itália) 


\section{Sociedade Brasileira de Cardiologia}

Presidente

Jadelson Pinheiro de Andrade

Vice-Presidente

Dalton Bertolim Précoma

Diretor Administrativo

Marcelo Souza Hadlich

Diretora Financeira

Eduardo Nagib Gaui

Diretor de Relações Governamentais

Daniel França Vasconcelos

Diretor de Comunicação

Carlos Eduardo Suaide Silva

Diretor de Qualidade Assistencial

José Xavier de Melo Filho

Diretor Científico

Luiz Alberto Piva e Mattos

Diretor de Promoção de Saúde

Cardiovascular - SBC/Funcor

Carlos Alberto Machado

Diretor de Relações

Estaduais e Regionais

Marco Antonio de Mattos

Diretor de Departamentos

Especializados

Gilberto Venossi Barbosa

Diretor de Tecnologia da Informação

Carlos Eduardo Suaide Silva

Diretor de Pesquisa

Fernando Bacal

Editor-Chefe Arquivos Brasileiros de Cardiologia

Luiz Felipe P. Moreira

Editor do Jornal SBC

Fábio Vilas-Boas Pinto

Coordenador do Conselho de Projeto Epidemiológico

David de Pádua Brasil
Coordenadores do Conselho de Ações Sociais

Alvaro Avezum Junior

Ari Timerman

Coordenadora do Conselho de Novos

Projetos

Glaucia Maria Moraes Oliveira

Coordenador do Conselho de Aplicação de Novas Tecnologias

Washington Andrade Macie

Coordenador do Conselho de Inserção do Jovem Cardiologista

Fernando Augusto Alves da Costa

Coordenador do Conselho de Avaliação da Qualidade da Prática Clínica e Segurança do Paciente

Evandro Tinoco Mesquita

Coordenador do Conselho de

Normatizações e Diretrizes

Harry Correa Filho

Coordenador do Conselho de Educação

Continuada

Antonio Carlos de Camargo Carvalho

Comitê de Atendimento de Emergência e Morte Súbita

Manoel Fernandes Canesin

Nabil Ghorayeb

Sergio Timerman

Comitê de Prevenção Cardiovascular Antonio Delduque de Araujo Travessa Sergio Baiocchi Carneiro

Regina Coeli Marques de Carvalho

Comitê de Planejamento Estratégico Fabio Sândoli de Brito

José Carlos Moura Jorge

Walter José Gomes

Comitê de Assistência ao Associado

Maria Fatima de Azevedo

Mauro José Oliveira Gonçalves

Ricardo Ryoshim Kuniyoshi

Comitê de Relações Internacionais

Antonio Felipe Simão

João Vicente Vitola

Oscar Pereira Dutra
Presidentes das Estaduais e Regionais da SBC

SBC/AL - Alfredo Aurelio Marinho Rosa

SBC/AM - Jaime Giovany Arnez Maldonado

SBC/BA - Augusto José Gonçalves de Almeida

SBC/CE - Eduardo Arrais Rocha

SBC/CO - Hernando Eduardo Nazzetta (GO)

SBC/DF - Renault Mattos Ribeiro Junior

SBC/ES - Antonio Carlos Avanza Junior

SBC/GO - Luiz Antonio Batista de Sá

SBC/MA - Magda Luciene de Souza Carvalho

SBC/MG - Maria da Consolação Vieira Moreira

SBC/MS - Sandra Helena Gonsalves de Andrade

SBC/MT - José Silveira Lage

SBC/NNE - Aristoteles Comte de Alencar Filho (AM)

SBC/PA - Claudine Maria Alves Feio

SBC/PB - Alexandre Jorge de Andrade Negri

SBC/PE - Silvia Marinho Martins

SBC/PI - Ricardo Lobo Furtado

SBC/PR - Álvaro Vieira Moura

SBC/RJ - Glaucia Maria Moraes Oliveira

SBC/RN - Carlos Alberto de Faria

SBC/RS - Justo Antero Sayão Lobato Leivas

SBC/SC - Conrado Roberto Hoffmann Filho

SBC/SE - Eduardo José Pereira Ferreira

SBC/SP - Carlos Costa Magalhães

SBC/TO - Adalgele Rodrigues Blois

\section{Presidentes dos Departamentos Especializados e Grupos de Estudos}

SBC/DA - Hermes Toros Xavier (SP)

SBC/DCC - Evandro Tinoco Mesquita (RJ)

SBC/DCM - Orlando Otavio de Medeiros (PE)

SBC/DCC/CP - Estela Suzana Kleiman Horowitz (RS)

SBC/DECAGE - Abrahão Afiune Neto (GO)

SBC/DEIC - João David de Souza Neto (CE)

SBC/DERC - Pedro Ferreira de

Albuquerque (AL)
SBC/DFCVR - José Carlos Dorsa Vieira Pontes (MS)

SBC/DHA - Weimar Kunz Sebba Barroso de Souza (GO)

SBC/DIC - Jorge Eduardo Assef (SP)

SBC/SBCCV - Walter José Gomes (SP)

SBC/SBHCI - Marcelo Antonio Cartaxo Queiroga Lopes (PB)

SBC/SOBRAC - Adalberto Menezes Lorga Filho (SP)

SBC/DCC/GAPO - Daniela Calderaro (SP)
SBC/DCC/GECETI - João Fernando Monteiro Ferreira (SP)

SBC/DCC/GEECABE - Luis Claudio Lemos Correia (BA)

SBC/DCC/GEECG - Carlos Alberto Pastore (SP)

SBC/DCP/GECIP - Angela Maria Pontes Bandeira de Oliveira (PE)

SBC/DERC/GECESP - Daniel Jogaib Daher (SP)

SBC/DERC/GECN - José Roberto Nolasco de Araújo (AL) 


\section{Arquivos Brasileiros de Cardiologia}

Volume 100, $\mathrm{N}^{\circ}$ 1, Suplemento 3, Janeiro 2013

Indexação: ISI (Thomson Scientific), Cumulated Index Medicus (NLM), SCOPUS, MEDLINE, EMBASE, LILACS, SciELO, PubMed

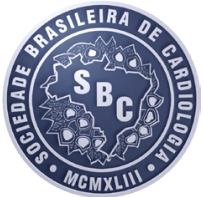

Av. Marechal Câmara, 160 - 3o andar - Sala 330 20020-907 • Centro • Rio de Janeiro, RJ • Brasil

Tel.: (21) 3478-2700

E-mail: arquivos@cardiol.br

www.arquivosonline.com.br

SCIELO: www.scielo.br

Departamento Comercial

Telefone: (11) 3411-5500

e-mail: comercialsp@cardiol.br

\section{Produção Editorial}

SBC - Núcleo Interno de Publicações
Produção Gráfica e Diagramação

SBC - Núcleo Interno de Design

Impressão

Prol Editora Gráfica

Tiragem

11.000 exemplares

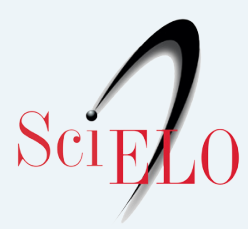

AMB

Filiada à Associação Médica Brasileira

Os anúncios veiculados nesta edição são de exclusiva responsabilidade dos anunciantes, assim como os conceitos emitidos em artigos assinados são de exclusiva responsabilidade de seus autores, não refletindo necessariamente a opinião da SBC.

Material de distribuição exclusiva à classe médica. Os Arquivos Brasileiros de Cardiologia não se responsabilizam pelo acesso indevido a seu conteúdo e que contrarie a determinação em atendimento à Resolução da Diretoria Colegiada (RDC) no 96/08 da Agência Nacional de Vigilância Sanitária (Anvisa), que atualiza o regulamento técnico sobre Propaganda, Publicidade, Promoção e informação de Medicamentos. Segundo o artigo 27 da insígnia, "a propaganda ou publicidade de medicamentos de venda sob prescrição deve ser restrita, única e exclusivamente, aos profissionais de saúde habilitados a prescrever ou dispensar tais produtos (...)".

Garantindo o acesso universal, o conteúdo científico do periódico continua disponível para acesso gratuito e integral a todos os interessados no endereço: www.arquivosonline.com.br.

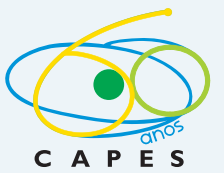

\section{Ministério da \\ Educação}

\section{Ministério da Ciência e Tecnologia}

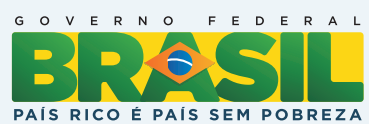




\section{Sumário}

1. Introdução página 4

1.1. Aspectos do perfil alimentar brasileiro página 4

1.2. Avaliação do consumo alimentar página 5

2. Da definição e metabolismo das gorduras página 5

3. Efeitos e recomendações do consumo de colesterol sobre mecanismos fisiopatológicos do processo aterosclerótico: biomarcadores e desfechos clínicos página 7

3.1. Colesterol página 7

3.2. Ovo. página 7

4. Efeitos e recomendações do consumo dos ácidos graxos saturados sobre mecanismos fisiopatológicos do processo aterosclerótico: biomarcadores e desfechos clínicos

4.1. Ácidos Graxos Saturados (SFA) página 8

4.2. Histórico de estudos SFA. página 8

4.3. Doença cardiovascular página 8

4.4. Recomendações de consumo de ácido graxo saturado página 9

4.5. Posicionamento sobre temas selecionados página 9

4.5.1. Coco e óleo de coco página 9

4.5.2. Óleo de palma página 9

4.5.3. Chocolate página 10

4.5.4. Manteiga página 10

4.5.5. Carne página 10

4.5.6. Queijos página 11

5. Efeitos e recomendações do consumo dos ácidos graxos monoinsaturados sobre mecanismos fisiopatológicos do processo aterosclerótico: biomarcadores e desfechos clínicos página 12

5.1. Ácidos Graxos Monoinsaturados (MUFA) página 12

5.1.1. Efeitos sobre o metabolismo lipídico página 12

5.1.2. Efeitos sobre o metabolismo glicídico página 12

5.1.3. Efeitos sobre a pressão arterial página 12

5.1.4. Outros efeitos sobre mecanismos relacionados à aterotrombose página 13

5.1.5. Efeitos sobre eventos cardiovasculares página 13

5.2. Recomendações. página 13

6. Efeitos e recomendações do consumo dos ácidos graxos poli-insaturados sobre mecanismos fisiopatológicos do processo aterosclerótico: biomarcadores e desfechos clínicos

6.2. Ácidos graxos poli-insaturados Ômega-3 de origem marinha (Docosaexaenoico (DHA) e eicosapentaenoico (EPA)) 


\section{Diretrizes}

6.2.3. Efeitos sobre a pressão arterial

página 14

6.2.4. Efeitos sobre a inflamação

6.2.5. Efeitos sobre a função endotelial

página 15

6.2.6. Efeitos sobre a aterosclerose

página 15

6.2.7. Efeitos antiarrítmicos

página 15

6.2.8. Efeitos sobre eventos cardiovasculares

página 15

6.2.9. Eventos arrítmicos e morte súbita

página 15

6.2.10. Subgrupo de pacientes com insuficiência cardíaca sistólica

página 16

6.3. Recomendações.

página 16

6.4. Notas sobre suplementos de Ômega-3

página 16

6.4.1. Administração

página 16

6.4.2. Efeitos colaterais

página 18

6.4.3. Segurança

página 18

6.5. Ácidos graxos poli-insaturados Ômega-3 de origem vegetal

página 18

6.5.1. Efeitos sobre o metabolismo lipídico

página 18

6.5.2. Efeitos sobre o metabolismo glicídico

página 18

6.5.3. Efeitos sobre a inflamação

página 18

6.5.4. Efeitos sobre eventos cardiovasculares

página 18

6.6. Recomendações.

página 18

6.7. Ácido graxo poli-insaturado N-6 (ALA)

página 19

6.7.1. Efeitos sobre o metabolismo lipídico

página 19

6.7.2. Efeitos sobre o metabolismo glicídico

6.7.3. Efeitos sobre a inflamação

6.7.4. Efeitos sobre eventos cardiovasculares

página 19

6.7.5. A relação Ômega-6/Ômega-3

página 19

6.8. Recomendações.

7. Efeitos e recomendações do consumo dos ácidos graxos poli-insaturados sobre mecanismos fisiopatológicos do processo aterosclerótico: biomarcadores e desfechos clínicos

7.1. Ácidos graxos Trans

7.1.1. Colesterol total e frações e triglicérides.

7.1.2. Glicemia e resistência a insulina

7.1.3. Biomarcadores inflamatórios

7.1.4. Aterosclerose e função endotelial

7.1.5. Estudos de desfecho cardiovascular

7.1.6. Relação indústria / Anvisa

8. Efeitos e recomendações do consumo dos ácidos graxos interestificados sobre mecanismos fisiopatológicos do processo aterosclerótico: biomarcadores e desfechos clínicos

8.1.1. Estudos com animais 
9.1. Modo de conservação, manipulação e preparo dos alimentos ricos em gorduras mono e poli-insaturadas e suas fontes alimentares

9.2. Aquisição dos produtos no mercado página 24

9.3. Manipulação página 24

9.4. Preparo de alimentos página 24

9.4.1. Do cozimento em água página 25

9.4.2. Do cozimento em óleo página 25

9.5. Fontes página 25

9.6. Ômega-3 em peixes de água fria página 26

9.7. Ômega-3 em peixes em geral página 27

Referências página 32 
 \\ MUMXLII \\ I Diretriz sobre o consumo de Gorduras e Saúde Cardiovascular}

\section{REALIZAC̄̃o}

Sociedade Brasileira de Cardiologia

\section{Coordenador de Normatizações e Diretrizes da SBC}

Harry Corrêa Filho

Coordenação Geral

Ana Carolina Moron Gagliardi

Ana Maria Lottenberg

Antonio Casella Filho

Daniel Branco Araujo

Daniel Magnoni

Fernando Y. Cesena

Hermes Toros Xavier

Raul Dias dos Santos Filho

Renato Jorge Alves

Roberta Soares Lara Cassani

\section{EDITOR}

Raul Dias dos Santos Filho

\section{Membros do Comitê}

André Arpadi Faludi; Bruno Geloneze; Carlos Scherr; Cristiane Kovacs; Cristina Tomazzela; Cyntia Carla; Daniel Barrera-Arellano;

Dennys Cintra; Eder Quintão; Edna Regina Nakandakare; Francisco A. H.Fonseca; Isabella Pimentel; José Ernesto dos Santos;

Marcelo Chiara Bertolami; Marcelo Rogero; Maria Cristina de Oliveira Izar; Miyoko Nakasato; Nágila Raquel Teixeira Damasceno; Raul Maranhão; Roberta Soares Lara Cassani; Rosana Perim; Silvia Ramos

Esta diretriz deverá ser citada como: Santos R.D., Gagliardi A.C.M., Xavier H.T., Magnoni C.D., Cassani R ., Lottenberg A.M. et al. Sociedade Brasileira de Cardiologia. I Diretriz sobre o consumo de Gorduras e Saúde Cardiovascular. Arq Bras Cardiol. 2013;100(1Supl.3):1-40

\section{Correspondência:}

Sociedade Brasileira de Cardiologia

Av. Marechal Câmara, 160/330 - Centro - Rio de Janeiro - CEP: 20020-907

e-mail: scb-da@cardiol.br 


\begin{tabular}{|c|c|c|c|c|c|c|c|}
\hline $\begin{array}{c}\text { Nomes Integrantes da } \\
\text { Diretriz }\end{array}$ & $\begin{array}{l}\text { Participou } \\
\text { de estudos } \\
\text { clínicos e/ou } \\
\text { experimentais } \\
\text { subvencionados } \\
\text { pela indústria } \\
\text { farmacêutica ou } \\
\text { de equipamentos } \\
\text { relacionados } \\
\text { à diretriz em } \\
\text { questão }\end{array}$ & $\begin{array}{c}\text { Foi } \\
\text { palestrante } \\
\text { em eventos } \\
\text { ou atividades } \\
\text { patrocinadas } \\
\text { pela indústria } \\
\text { relacionados } \\
\text { à diretriz em } \\
\text { questão }\end{array}$ & $\begin{array}{c}\text { Foi (é) } \\
\text { membro do } \\
\text { conselho } \\
\text { consultivo } \\
\text { ou diretivo } \\
\text { da indústria } \\
\text { farmacêutica } \\
\text { ou de } \\
\text { equipa- } \\
\text { mentos }\end{array}$ & $\begin{array}{c}\text { Participou } \\
\text { de comitês } \\
\text { normativos } \\
\text { de estudos } \\
\text { científicos } \\
\text { patroci- } \\
\text { nados pela } \\
\text { indústria }\end{array}$ & $\begin{array}{l}\text { Recebeu auxílio } \\
\text { pessoal ou } \\
\text { institucional da } \\
\text { indústria }\end{array}$ & $\begin{array}{c}\text { Elaborou textos } \\
\text { científicos em } \\
\text { periódicos } \\
\text { patroci- } \\
\text { nados pela } \\
\text { indústria }\end{array}$ & $\begin{array}{c}\text { Tem ações } \\
\text { da } \\
\text { indústria }\end{array}$ \\
\hline Ana Carolina Moron Gagliardi & Não & Não & Não & Não & Não & Não & Não \\
\hline Ana Maria Lottenberg & Não & Não & Não & Não & Não & Não & Não \\
\hline André Arpadi Faludi & Não & Não & Não & Não & Não & Não & Não \\
\hline Antonio Casella & Não & Não & Não & Não & $\begin{array}{c}\text { Astra-Zeneca, } \\
\text { Daiichi-Sankyio } \\
\text { E Msd }\end{array}$ & Msd & Não \\
\hline Bruno Geloneze & Não & Não & Não & Não & Não & Não & Não \\
\hline Carlos Scherr & Não & Unilever & Não & Não & Não & Não Mencionado & Não \\
\hline Cristiane Kovacs & Não & Não & Não & Não & Não & Não & Não \\
\hline Cristina Tomazzela & Não & Não & Não & Não & Não & Não & Não \\
\hline Cyntia Carla & Não & Unilever & Não & Não & Não & Não & Não \\
\hline Daniel Barrera-Arellano & Não & Não & Não & Não & Não & Não & Não \\
\hline Daniel Branco de Araujo & Não & Não & Não & Não & $\begin{array}{c}\text { Sim / Patrocínio } \\
\text { Para Congressos } \\
\text { (Industrias Não } \\
\text { Relacionadas A } \\
\text { Diretriz Em Questão) }\end{array}$ & Não & Não \\
\hline Daniel Magnoni & Não & Não & Não & Não & Não & Não & Não \\
\hline Dennys Cintra & Não & Não & Não & Não & Não & Não & Não \\
\hline Eder Quintão & Não & Não & Não & Não & Msd & Não & Não \\
\hline Edna Regina Nakandakare & Não & Não & Não & Não & Não & Não & Não \\
\hline Fernando Cesena & Não & Não & Astrazeneca & Não & Não & Não & Não \\
\hline Francisco A. H.Fonseca & Não & Unilever & $\begin{array}{l}\text { Msd, Biolab, } \\
\text { Astrazeneca }\end{array}$ & $\begin{array}{l}\text { Novartis, } \\
\text { Aché }\end{array}$ & $\begin{array}{l}\text { Msd, Biolab, Ache, } \\
\text { Astrazeneca, Roche }\end{array}$ & $\begin{array}{c}\text { Bayer, } \\
\text { Astrazeneca, } \\
\text { Msd }\end{array}$ & Não \\
\hline Hermes T. Xavier & Não & Não & Não & Não & Não & Não & Não \\
\hline Isabella Pimentel & Não & Não & Não & Não & Não & Não & Não \\
\hline José Ernesto dos Santos & Não & Não & Não & Não & Não & Não & Não \\
\hline Marcelo Chiara Bertolami & Unilever - Becel & $\begin{array}{l}\text { Unilever } \\
\text { - Becel }\end{array}$ & Não & Não & Não & Unilever - Becel & Não \\
\hline Marcelo Rogero & Não & Não & Não & Não & Não & Sim / Nestlé & Não \\
\hline Maria Cristina de Oliveira Izar & Não & Biolab & Não & Não & Não & Não & Não \\
\hline Miyoko Nakasato & Não & Não & Não & Não & Não & Não & Não \\
\hline $\begin{array}{c}\text { Nágila Raquel Teixeira } \\
\text { Damasceno }\end{array}$ & Não & Não & Não & Não & Não & Unilever & Não \\
\hline Raul Dias dos Santos Filho & Unilever & Não & Não & Não & Não & Não & Não \\
\hline Raul Maranhão & Não & Não & Não & Não & Não & Não & Não \\
\hline Renato Jorge Alves & Não & Não & Não & Não & Não & Não & Não \\
\hline Roberta Soares Lara Cassani & Não & Não & Não & Não & Não & Não & Não \\
\hline Rosana Perim & Não & Não & Não & Não & Não & Não & Não \\
\hline Silvia Ramos & Não & Não & Não & Não & Não & Não & Não \\
\hline
\end{tabular}




\section{Diretrizes}

\section{Definição do grau dos níveis de evidência}

\section{Recomendações}

Classe I: Condições para as quais há evidências conclusivas e, na sua falta, consenso geral de que o procedimento é seguro útil/eficaz.

Classe II: Condições para as quais há evidências conflitantes e/ou divergência de opinião sobre segurança e utilidade/ eficácia do procedimento.

Classe Ila: Peso ou evidência/opinião a favor do procedimento. A maioria aprova.

Classe IIb: Segurança e utilidade/eficácia menos bem estabelecidas, não havendo predomínio de opniões a favor.

Classe III: Condições para as quais há evidências e/ou consenso de que o procedimento não é útil/eficaz e, em alguns casos, pode ser prejudicial.

\section{Evidências}

Nível A: Dados obtidos a partir de múltiplos estudos randomizados de bom porte, concordantes e/ou de Metanálise robusta de estudos clínicos randomizados.

Nível B: Dados obtidos a partir de Metanálise menos robusta, a partir de um único estudo randomizado ou de estudos não randomizados (observacionais).

Nível C: Dados obtidos de opiniões consensuais de especialistas. 


\section{Siglas utilizadas nos textos e nas tabelas}

\begin{tabular}{|c|c|}
\hline Abreviações & Significado \\
\hline OMS & Organização Mundial da Saúde \\
\hline DCV & Doença Cardiovascular \\
\hline HDL-C & Lipoproteína de alta densidade \\
\hline LDL-C & Lipoproteína de baixa densidade \\
\hline $\mathrm{CH}$ & Carboidrato \\
\hline POF & Pesquisa de orçamento familiar \\
\hline$\%$ & Porcentagem \\
\hline QFA & Questionário de frequência alimentar \\
\hline R24h & Recordatório alimentar de 24 horas \\
\hline ACAT & Acilcolesteril-aciltransferase \\
\hline MUFA & Ácido graxo monoinsaturado \\
\hline PUFA & Ácido graxo polinsaturado \\
\hline $\mathrm{DHA}$ & Ácido docosahexaenoico \\
\hline EPA & Ácido eicosapentaenoico \\
\hline ALA & Ácido alfalinolênico \\
\hline Apo-B & Apolipoproteína B \\
\hline Apo-E & Apolipoproteína $\mathrm{E}$ \\
\hline Apo-B100 & Apolipoproteína B 100 \\
\hline AL & Ácido linoleico \\
\hline AA & Ácido araquidônico \\
\hline VLDL & Lipoproteína rica em triglicérides \\
\hline $\mathrm{mg}$ & Miligrama \\
\hline $\mathrm{AHA}$ & American Heart Association \\
\hline $\mathrm{mmol} / \mathrm{L}$ & Milimol por litro \\
\hline$A G$ & Ácido graxo \\
\hline TG & Triglicérides \\
\hline CT & Colesterol total \\
\hline FDA & Food and Drug Administration \\
\hline $\mathrm{WHO}$ & $\begin{array}{l}\text { World Health Organization ou Organização } \\
\text { Mundial da Saúde }\end{array}$ \\
\hline VCT & Valor calórico total \\
\hline IMC & Índice de massa corporal \\
\hline GLP-1 & Glucagon-like peptide-1 \\
\hline HAS & Hipertensão arterial sistêmica \\
\hline
\end{tabular}

\begin{tabular}{ll}
\hline Abreviações & Significado \\
\hline PA & Pressão arterial \\
\hline CV & Cardiovascular \\
\hline RR & Risco relativo \\
\hline g & Grama \\
\hline mmHg & Milímetro de mercúrio \\
\hline PCR & Proteína C Reativa \\
\hline IAM & Infarto agudo do miocárdio \\
\hline CF & Classe funcional \\
\hline IC & Insuficiência cardíaca \\
\hline IM & Infarto agudo do miocárdio \\
\hline CDI & Cardiodesfibrilador implantavel \\
\hline MSC & Morte súbita cardíaca \\
\hline CETP & Cholesteryl ester transfer protein \\
\hline FAS & Ácido graxo sintase \\
\hline ACATitido Nacidocalorias \\
\hline SREBP-1C & Proteína de ligação ao elemento responsive a \\
\hline esteróides 1c
\end{tabular}




\section{Introdução}

Segundo a Organização Mundial de Saúde (OMS), a Doença Cardiovascular (DCV) é a principal causa de morte no mundo, perfazendo $30 \%$ das mortes globais ${ }^{1}$, taxa praticamente idêntica à encontrada no Brasil' ${ }^{1}$. Mais de $80 \%$ das mortes por DCV no mundo ocorrem em países de média e de baixa rendas ${ }^{2}$.

De um modo geral, a base fisiopatológica para os eventos cardiovasculares é a aterosclerose, processo que se desenvolve ao longo de décadas de maneira insidiosa, podendo os primeiros sinais ser fatais ou altamente limitantes.

A formação da placa de ateroma na parede dos vasos sanguíneos, bem como suas consequências clínicas (infarto do miocárdio e Acidente Vascular Encefálico [AVE]) associam-se intimamente com determinados fatores de risco cardiovascular, como hipercolesterolemia, hipertrigliceridemia, diminuição do HDL-c, hipertensão arterial sistêmica, diabetes mellitus e obesidade.

Além disso, a aterosclerose caracteriza-se por um processo inflamatório crônico da parede vascular, e a elevação de marcadores inflamatórios séricos, como a proteína C-reativa, tem se associado a maior risco de eventos cardiovasculares.

A base para a prevenção de eventos cardiovasculares tem sido, nas últimas décadas, o controle rigoroso dos fatores de risco cardiovascular. O controle da pressão arterial efetivamente diminui a chance de eventos cardiovasculares, sobretudo de $\mathrm{AVE}^{3}$. No que diz respeito à dislipidemia, diversos estudos epidemiológicos e de intervenção, sobretudo com estatinas, demonstram inequivocamente que a redução dos níveis plasmáticos de LDL-c diminui a chance de eventos cardiovasculares, seja no caso de quem já apresentou um evento (prevenção secundária), seja no de quem nunca o apresentou (prevenção primária). De fato, a primeira meta lipídica para prevenção cardiovascular é o LDL-c ${ }^{4}$.

Embora não se tenha o mesmo grau de evidência, a redução dos níveis de triglicérides e a elevação dos de HDL-c também são consideradas potencialmente benéficas para a inibição do processo aterotrombótico. Subanálises de ensaios clínicos argumentam a favor da redução da concentração sérica de triglicérides e estudos com métodos de imagem mostram ação favorável de terapias baseadas em HDL sobre a placa aterosclerótica ${ }^{5}$.

Com relação ao componente inflamatório, embora não exista comprovação inequívoca que terapias dirigidas especificamente para a redução da inflamação reduzam o risco cardiovascular, pode-se aventar a hipótese de que estratégias medicamentosas ou modificações de estilo de vida que limitem o processo inflamatório limitem a progressão das placas de ateroma e/ou reduzam a sua vulnerabilidade a fenômenos de ruptura, com possíveis benefícios clínicos.

Hoje está claro que diferentes padrões dietéticos modulam diferentes aspectos do processo aterosclerótico e fatores de risco cardiovasculares, como níveis lipídicos no plasma, resistência a insulina e metabolismo glicídico, pressão arterial, fenômenos oxidativos, função endotelial e inflamação vascular. Consequentemente, o padrão alimentar interfere na chance de eventos ateroscleróticos.
O consumo de gordura saturada e trans é classicamente relacionado com elevação do LDL-c plasmático e aumento de risco cardiovascular. A substituição de gordura saturada da dieta por mono e poli-insaturada é considerada uma estratégia para o melhor controle da hipercolesterolemia e consequente redução da chance de eventos clínicos.

As repercussões da ingestão de gordura, no entanto, não se restringem ao metabolismo lipídico; o tipo de gordura ingerida pode influenciar também outros fatores de risco, como a resistência a insulina e a pressão arterial.

A importância dos carboidratos $(\mathrm{CH})$ na gênese da doença cardiovascular também deve ser ressaltada. É amplamente aceito que a ingestão aumentada de $\mathrm{CH}$, especialmente os de rápida absorção, favorece um desequilíbrio entre a oferta de lipídeos e os demais nutrientes, possibilitando o estabelecimento de hipercolesterolemia. Além disso, o elevado consumo de carboidratos refinados exerce efeito direto no excesso de peso e desenvolvimento da obesidade. Alterações pós-prandiais, como hiperglicemia, hiperinsulinemia e hipertrigliceridemia, também têm se associado a risco cardiovascular aumentado. Neste sentido, os $\mathrm{CH}$ ideais para melhorar o dismetabolismo nutricional pós-prandial incluem aqueles com menor índice glicêmico, menor densidade calórica, maiores teores de fibras e água.

Dessa forma, esta Diretriz tem por finalidade:

- Rever as evidências científicas dos principais efeitos dos diferentes tipos de ácidos graxos sobre fatores de risco cardiovasculares, o processo aterosclerótico e eventos clínicos;

- Rever as fontes principais dos diferentes ácidos graxos nos alimentos no Brasil;

- Estabelecer graus de recomendação e níveis de evidência para diferentes estratégias e padrões dietéticos que se relacionem com o risco cardiovascular;

- Difundir o conhecimento atual entre profissionais de saúde e a população geral, visando reduzir as taxas de eventos cardiovasculares no país.

\subsection{Aspectos do perfil alimentar brasileiro}

O processo de transição nutricional brasileiro é multifatorial e caracteriza-se por alterações sequenciais do padrão da dieta e da composição corporal dos indivíduos, resultantes de mudanças sociais, econômicas, demográficas, tecnológicas e culturais que afetaram diretamente o estilo de vida e o perfil de saúde da população. A presença de desnutrição, deficiência de micronutrientes, excesso de peso e outras doenças crônicas não transmissíveis coexistindo nas mesmas comunidades e, muitas vezes, no mesmo domicílio caracteriza o cenário da transição nutricional. As principais mudanças ocorreram nas últimas duas décadas com a adoção de um padrão dietético com elevado teor de gordura saturada e de açúcar, além de alimentos com baixo teor de fibras. Soma-se ainda uma redução dos níveis de atividade física ${ }^{6}$.

De acordo com Pesquisa de Orçamentos Familiares - POF 2008-2009, comparada à mesma pesquisa realizada em 20022003, a evolução do consumo de alimentos no domicílio indica aumento na proporção de alimentos industrializados, 
como pães (de 5,7\% para 6,4\%), embutidos (de 1,78\% para $2,2 \%$ ), biscoitos (de $3,1 \%$ para $3,4 \%$ ), refrigerantes (de $1,5 \%$ para 1,8\%) e refeições prontas (de 3,3\% para $4,6 \%)^{7}$. Em relação à distribuição de macronutrientes, o perfil atual mostra que 59\% das calorias estão representadas por carboidratos; $12 \%$, por proteínas; e 29\%, por lipídeos ${ }^{7}$. Nas regiões economicamente mais desenvolvidas (Sul, Sudeste e CentroOeste) e, de modo geral, no meio urbano e entre famílias com maior renda, existe consumo elevado de gorduras, em especial as saturadas ${ }^{7}$.

A mudança na composição nutricional associada à disponibilidade domiciliar de alimentos evidencia diminuição do consumo de carboidratos em detrimento do aumento do teor em gorduras e proteínas. A fração dos carboidratos que mais se reduz é a que exclui os açúcares livres, enquanto a participação das proteínas de origem animal aumentou ${ }^{7}$.

Quanto maior o rendimento das famílias, maior o consumo de gorduras e menor o de carboidratos ${ }^{7}$. A contribuição mínima de $55 \%$ de carboidratos para as calorias totais não se cumpre para a classe de renda mensal superior a 15 salários mínimos, com o agravante de que cerca de 30\% dos carboidratos da dieta nessa classe de renda (16,5\% em 54,6\%) correspondem a açúcares livres (açúcar de mesa, rapadura, mel e açúcares adicionados a alimentos processados) ${ }^{7}$.

Em relação às gorduras, o limite máximo de 30\% das calorias totais é ultrapassado a partir da classe de renda mensal de mais de seis salários mínimos ${ }^{7}$. Gorduras saturadas tendem a aumentar com a renda, e o limite para esse nutriente $(10 \%$ das calorias totais) é alcançado na classe de renda mensal entre 10 e 15 salários mínimos (9,5\%), e ultrapassado na classe de mais de 15 salários mínimos (10,6\% das calorias totais) ${ }^{7}$. O limite máximo de 10\% de calorias oriundas de açúcares é ultrapassado em todas as classes de rendimentos ${ }^{7}$. Somado a esses aspectos, outras características negativas dos padrões de consumo alimentar em todo o país e em todas as classes de renda são a participação insuficiente de frutas $(2,0 \%)$ e verduras e legumes $(0,8 \%)$ na alimentação ${ }^{7}$.

O consumo mínimo recomendado de frutas, legumes e verduras é de $9 \%$ a $12 \%$ da energia diária consumida ${ }^{8}$. Esse padrão dietético se associa ao aumento do excesso de peso e obesidade da população brasileira. As prevalências de excesso de peso e de obesidade aumentaram continuamente ao longo dos quatro inquéritos nos dois gêneros ${ }^{7}$. Nos 34 anos decorridos de 1974-1975 a 2008-2009, a prevalência de excesso de peso em adultos aumentou em quase três vezes no sexo masculino (de $18,5 \%$ para $50,1 \%$ ) e em quase duas vezes no sexo feminino (de $28,7 \%$ para $48,0 \%)^{7}$. No mesmo período, a prevalência de obesidade aumentou em mais de quatro vezes para homens (de 2,8\% para 12,4\%) e em mais de duas vezes para mulheres (de $8,0 \%$ para $16,9 \%)^{7}$. Aumentos contínuos na prevalência do excesso de peso e da obesidade entre homens ocorrem também em todas as regiões brasileiras ${ }^{7}$.

\subsection{Avaliação do consumo alimentar}

O estudo das associações entre dieta e alterações metabólicas, fatores de risco ou doenças requer uma avaliação detalhada e fidedigna da ingestão alimentar. O uso de ferramentas validadas e reprodutíveis aumenta a acurácia e diminui os possíveis vieses que permeiam a relação entre dieta ingerida e o relato do consumo. Procedimentos metodológicos são planejados de forma criteriosa, com a finalidade de se estimar os possíveis erros de medição, inerentes da própria metodologia, assim como aqueles ligados ao indivíduo (subrelato e subestimação) $)^{9,10}$.

De uma forma geral, os métodos que avaliam o consumo alimentar são imprecisos. Não obstante, o Questionário de Frequência Alimentar (QFA) e o Recordatório de 24h (R24h) são considerados os principais instrumentos utilizados para coleta de dados dietéticos. O elemento essencial do QFA é justamente aquele em que o R24h é impreciso, ou seja, capturar a probabilidade de consumo da maioria dos alimentos, em um determinado período pregresso de tempo, em geral o ano anterior ${ }^{11}$. Essa característica permite detalhar a dieta habitual individual ou de um grupo populacional, o que é de fundamental importância na estimativa dos fatores dietéticos a que foram expostos, bem como na investigação de possíveis associações de interesse.

O uso integrado do QFA e R24h pode se constituir em importante elemento na triagem de sujeitos mais suscetíveis ao desenvolvimento de DCV e morbidades associadas, possibilitando o aconselhamento preventivo para a adoção de hábitos alimentares e estilo de vida mais saudáveis.

\section{Da definição e metabolismo das gorduras}

A influência dos ácidos graxos ingeridos sobre os fatores de risco das doenças cardiovasculares e sobre as concentrações plasmáticas de lípides e lipoproteínas tem sido amplamente demonstrada em diversos estudos experimentais e populacionais ${ }^{12-15}$.

Os ácidos graxos são classificados pelo comprimento da cadeia de carbono, por número de duplas ligações na cadeia de carbono e pela configuração das duplas ligações. Essas características químicas, associadas à quantidade de gordura ingerida na alimentação, são determinantes do efeito da ingestão dos ácidos graxos na concentração plasmática de colesterol e sua distribuição nas lipoproteínas.

Os ácidos graxos podem ser divididos em saturado e insaturados, além de colesterol.

Os ácidos graxos saturados podem ser divididos em dois grupos: cadeia média (entre 8 e 12 átomos de carbono na cadeia) e cadeia longa (acima de 14 átomos de carbono). Após a absorção intestinal, os de cadeia média são transferidos para a circulação sanguínea. São transportados ligados à albumina, pela veia porta, diretamente para o fígado, onde são metabolizados, não sendo responsáveis pelo aumento do colesterol sérico.

Os principais ácidos graxos saturados de cadeia longa são: mirístico (14:0), encontrado no leite e seus derivados; palmítico (16:0), cujas principais fontes são a gordura animal e o óleo de palma; esteárico (18:0), presente na gordura do cacau. O ácido palmítico é o mais abundante na alimentação humana. Os ácidos graxos saturados (SFA) de cadeia longa encontram-se no estado sólido à temperatura ambiente. 
Após a absorção, os ácidos graxos (AG) de cadeia longa são esterificados nos enterócitos, formando os triglicérides; são então transportados pelos quilomícrons no sistema linfático e em seguida na corrente sanguínea. Os triglicérides dos quilomícrons são hidrolisados pela lipoproteína lípase, liberando os ácidos graxos para os tecidos, onde são reesterificados, formando novamente os triglicérides, forma de armazenamento da gordura no organismo.

De maneira geral, a gordura saturada (C12:0, C14:0 e C16:0) eleva a concentração plasmática de colesterol, especialmente o C14:0, enquanto o C18:0 é neutro em seus efeitos sobre o colesterol. Diversos mecanismos são propostos para essa alteração, entre eles: redução dos receptores de LDL hepáticos ${ }^{16}$; maior atividade da ACAT (acilcolesterilaciltransferase), aumentando a esterificação do colesterol das lipoproteínas contendo apo $\mathrm{B}^{17}$; aumento na quantidade de colesterol esterificado transportado nas LDL, devido à conformação química retilínea dos ácidos graxos saturados ${ }^{18}$.

Os ácidos graxos insaturados são classificados em razão do número de dupla ligações, em mono ou poli-insaturado; são encontrados especialmente na configuração cis da dupla ligação. A localização da primeira dupla ligação da cadeia carbônica a partir do grupo metila identifica a série do ácido graxo, por meio da letra $\omega$, sendo os principais $\omega-3$, $\omega-6$ e $\omega-9$.

Os ácidos graxos monoinsaturados possuem uma dupla ligação na cadeia carbônica, e o mais comum encontrado na natureza é o oleico (C18:1), série $\omega$-9, com maior concentração no óleo de oliva.

O conceito mais defendido é de que o consumo de MUFA não afeta significativamente os níveis de colesterol total circulantes, enquanto o consumo de SFA aumenta os níveis de colesterol ${ }^{19}$. Em uma Metanálise de 14 estudos controlados entre 1983 e 1994, dietas ricas em óleos ricos em MUFA versus PUFA mostraram efeitos similares sobre o LDL-c e o HDL-c, enquanto os PUFA proporcionaram um discreto efeito redutor sobre os triglicerídeos ${ }^{20}$. Dessa forma, a substituição de SFA por MUFA reduz o LDL-c de forma semelhante à substituição por PUFA.

Os ácidos graxos Ômega-3 são compreendidos por: ácido docosaexaenoico (DHA) e ácido eicosapentaenoico (EPA), de origem marinha e alfalinolênico (ALA) de origem vegetal. Esses exercem inúmeros efeitos sobre diferentes aspectos fisiológicos e do metabolismo que podem influenciar a chance de desenvolvimento de doenças cardiovasculares, tais como melhora da função autonômica, antiarrítmico, diminuição da agregação plaquetária e da pressão arterial, melhora da função endotelial, estabilização da placa de ateroma e de triglicérides. O efeito sobre trigliceridemia se deve à ação desse ácido graxo na redução da síntese de APO-B e aumento do seu catabolismo, simultaneamente pode acelerar o catabolismo dos quilomícrons por estimular a atividade da enzima lipoproteína lípase. As principais fontes de ALA são os óleos vegetais, especialmente de soja e canola; já EPA e DHA são mais encontrados em peixes de águas muito frias e profundas.

Os Ômega-6 são chamados de essenciais porque não podem ser sintetizados pelos seres humanos e outros mamíferos; portanto, só podem ser obtidos mediante ingestão ${ }^{21}$.
O Ácido Linoleico (AL), um ácido graxo de 18 carbonos com duas duplas ligações (18:2 Ômega-6), é o principal ácido graxo Ômega-6, encontrado especialmente em óleos vegetais como os de soja, cártamo, milho e canola.

O Ômega-6 é necessário para muitas funções fisiológicas no ser humano.

Embora as quantidades mínimas de Ômega- 6 a serem ingeridas diariamente por adultos saudáveis não estejam ainda bem estabelecidas, estimativas derivadas de vários estudos sugerem um consumo de pelo menos 5\%-10\% de energia total a ser consumida ao dia $^{22}$, devendo ser considerado que sua ingestão varia de acordo com o país. Dados norte-americanos sugerem, em indivíduos com idade entre 19 e 50 anos, uma ingestão adequada de AL de cerca de 14,8 g/dia, ou seja, 6\% a $7 \%$ da energia total diária consumida ${ }^{23}$.

Após a ingestão, o AL pode sofrer alterações de dessaturação e alongamento para formar outros ácidos graxos poli-insaturados Ômega-6, tais como os ácidos gamalinolênico e di-homogamalinolênico, e este último é metabolicamente convertido para o ácido araquidônico (AA; 20:04 Ômega-6), que serve de substrato para uma grande variedade de importantes metabólitos, especialmente de algumas moléculas pró-inflamatórias.

Os ácidos graxos Trans são Isômeros geométricos dos ácidos graxos insaturados, produzidos a partir da fermentação de bactérias em ruminantes, sendo encontrados em quantidades insignificantes na carne e no leite ${ }^{24}$. A produção desses ácidos graxos também ocorre por meio da hidrogenação parcial de óleos vegetais, sendo o mais comum o ácido elaídico (18:1,9t). Tal processo se aplica aos óleos vegetais líquidos à temperatura ambiente, com o objetivo de conferir consistência de semissólida a sólida a essas gorduras. Na configuração Trans, os dois átomos de hidrogênio ligados ao carbono na dupla ligação estão localizados em lados opostos, formando uma molécula mais rígida e com configuração retilínea, assemelhando-se, assim, ao ácido graxo saturado. Ácidos graxos Trans estão presentes em diversos produtos industrializados que utilizam esse tipo de gordura, tendo como exemplos mais frequentes os biscoitos - incluindo de maizena e de polvilho - , sorvetes cremosos e tortas. Podem ser encontrados também em diversos produtos de panificação, como pão francês, folhados, pão de batata e pão de queijo.

As gorduras interesterificadas podem ser produzidas industrialmente a partir de método enzimático ou químico, sendo este último o preponderante. A Interesterificação química é utilizada para modificar óleos e gorduras, aumentado o seu ponto de fusão, possibilitando a formação de uma gordura mais dura. Esse processo modifica as propriedades físicas de óleos por meio do rearranjo aleatório da distribuição de ácidos graxos no glicerol sem alterar a composição química do óleo utilizado inicialmente. Dessa forma, ocorre a introdução de ácidos graxos saturados na posição sn-2 do glicerol, e essa posição normalmente é ocupada por ácidos graxos insaturados em óleos vegetais.

Em razão dos efeitos nocivos de ácidos graxos trans sobre a saúde, especialmente por aumentar o risco cardiovascular, ocorreram diversas ações simultâneas provenientes tanto de Agências Reguladoras de Saúde quanto de Sociedades responsáveis pela elaboração de Diretrizes Nutricionais, no sentido de recomendar a redução do consumo desses ácidos graxos pela população mundial. Desse modo, foram 
implementadas políticas públicas para redução do consumo de gorduras trans, o que obrigou a indústria de alimentos a alterar a fonte de gordura utilizada, adequando os seus produtos.

Com a finalidade de garantir características organolépticas semelhantes às proporcionadas pelas gorduras trans, a indústria optou pelas gorduras interesterificadas como uma alternativa plausível, em razão de conferirem textura e sabor desejáveis. Embora as gorduras interesterificadas sejam isentas de trans, observa-se aumento na quantidade de ácidos graxos saturados, além da modificação na distribuição de ácidos graxos nas posições 1, 2 e 3 da molécula de glicerol, cujas alterações podem induzir aumento do risco de desenvolver doenças cardiovasculares.

Os dados da literatura mostram resultados controversos em relação à ação dessas gorduras sobre o perfil lipídico, especialmente pelo fato de que diferentes tipos de ácidos graxos podem ser utilizados na sua formulação. Diante disso, há a necessidade da condução de estudos bem elaborados que avaliem não somente a ação dos diversos ácidos graxos saturados utilizados, mas também as possíveis implicações metabólicas decorrentes da modificação da posição desses ácidos graxos na molécula de glicerol. Além disso, não há publicações que evidenciem a sua ação a respeito do desenvolvimento da placa aterosclerótica.

Dessa forma, pesquisas experimentais e clínicas que contribuam para melhor elucidar a ação dessas gorduras sobre o risco cardiovascular são importantes para garantir a segurança quanto ao seu consumo.

Já o colesterol alimentar encontra-se nas gorduras de origem animal, quase que totalmente na forma livre (não esterificado). Suas principais fontes alimentares são gema de ovo, leite e derivados, camarão, carne bovina, pele de aves e vísceras. Estudos epidemiológicos clássicos evidenciam forte associação entre o alto consumo de colesterol com maior incidência de aterosclerose ${ }^{19,25-32}$, conforme demonstrado em populações com ingestão muito alta de alimentos ricos em colesterol. Apesar disso, no tratamento da hipercolesterolemia, sabe-se que o colesterol alimentar exerce pouca influência sobre a concentração plasmática de colesterol e aterosclerose precoce. Aproximadamente, 56\% do colesterol da dieta são absorvidos. Os ácidos graxos exercem maior influencia sobre a colesterolemia

\section{Efeitos e recomendações do consumo de colesterol sobre mecanismos fisiopato- lógicos do processo aterosclerótico: biomarcadores e desfechos clínicos}

\subsection{Colesterol}

O colesterol alimentar é um composto vital para o organismo, essencial na formação das membranas das células, na produção de hormônios sexuais, da vitamina D e de sucos digestivos, além de desempenhar papel importante nos tecidos nervosos e originar sais biliares. Estudos epidemiológicos clássicos evidenciam forte associação entre alto consumo de colesterol e maior incidência de aterosclerose ${ }^{12,33-35}$, conforme demonstrado em populações com ingestão muito alta de alimentos ricos em colesterol ${ }^{36-39}$. O colesterol alimentar é encontrado em gorduras animais, como ovos, leite e derivados, carne vermelha, camarão, pele de aves e vísceras, as principais fontes.

A resposta da colesterolemia decorrente do consumo de colesterol alimentar é variável em animais e humanos, e as razões para diferenças interpessoais ainda não estão totalmente esclarecidas. Sabe-se, no entanto, que alguns genótipos podem influenciar as concentrações de LDL e VLDL. Há sugestões de que a absorção intestinal de colesterol seja governada pelo genótipo das apoE-LP; indivíduos portadores do alelo E-4 apresentam maior absorção do colesterol alimentar, e os alelos E-2, menor absorção desse, quando submetidos a dieta rica em colesterol ${ }^{40-42}$.

Em razão da controvérsia sobre efeito colesterolemizante do colesterol alimentar, diversas diretrizes internacionais recomendam a restrição de gorduras totais e do colesterol da dieta, objetivando redução e controle do colesterol e LDL-c plasmáticos ${ }^{43,44}$.

\subsection{Ovo}

O ovo é um alimento com baixo custo e uma excelente fonte de vários nutrientes, tais como folato, riboflavina, selênio, colina e vitaminas A, D, E, K e B12, além de sais minerais (ferro, fósforo, cálcio, magnésio, sódio, potássio, cloro, iodo, manganês, enxofre, cobre e zinco), proteína de alta qualidade e lipídeo, que tornam biodisponíveis importantes nutrientes, como luteína e zeaxantina, associadas com a prevenção da degeneração macular, além de fonte de gorduras saturadas e colesterol. Vale lembrar que os lípides, minerais e vitaminas estão presentes quase que totalmente na gema, sendo a clara constituída especialmente pelas proteínas.

Um simples ovo contém de 50 a 250 mg de colesterol, dependendo do tamanho. As recomendações atuais ${ }^{45}$ restringem o consumo de ovo e limitam o consumo de colesterol em até $300 \mathrm{mg}$ ao dia. No entanto, essa recomendação sobre ovo tem sido revista e novas pesquisas indicam que a ingestão de um ovo ao dia pode ser aceitável, se outros alimentos ricos em colesterol forem limitados na dieta.

A grande quantidade de nutrientes (DHA, proteínas e vitaminas) pode contribuir para controlar a colesterolemia ${ }^{46}$. Isso pode ser uma das razões das diferentes respostas do ovo à colesterolemia. Outra possível razão seria o alto consumo de gordura saturada e colesterol por certas populações, e o ovo pouco acrescentará como risco para doença cardiovascular ${ }^{47,48}$.

Há estimativa de que $30 \%$ da população respondem negativamente à ingestão de colesterol. Se um indivíduo responsivo ingerir dois ovos por dia, pode exceder as recomendação do American Heart Association (AHA), ultrapassando o limite superior de consumo em $126 \mathrm{mg}$, que pode sugerir que ele pode ter um aumento de 0,050,07 mmol/L no colesterol total plasmático. Há populações que podem se beneficiar do decréscimo de ingestão de colesterol dietético, como aquelas com diabetes, que podem possuir anormalidades no mecanismo para o transporte de colesterol ${ }^{49}$.

Deve-se ter cuidado na forma de preparo do ovo; quando esse é frito ou mexido, há adição de gorduras, aumentando as calorias e dependendo do tipo de gordura, elevando o colesterol. 


\section{Diretrizes}

\begin{tabular}{lcc}
\hline Recomendação & $\begin{array}{c}\text { Grau de } \\
\text { recomendação }\end{array}$ & $\begin{array}{c}\text { Nível de } \\
\text { evidência }\end{array}$ \\
\hline $\begin{array}{l}\text { O consumo de colesterol alimentar } \\
\text { deve ser < 300 mg/dia para auxiliar } \\
\text { controle da colesterolemia }\end{array}$ & । & A \\
\hline $\begin{array}{l}\text { O consumo de ovo deve ser } \\
\text { moderado (até 1 por dia) para } \\
\text { população em geral e restrito para } \\
\text { diabéticos. }\end{array}$ & \|la & B \\
\hline
\end{tabular}

\section{Efeitos e recomendações do consumo dos ácidos graxos saturados sobre mecanismos fisiopatológicos do processo aterosclerótico: biomarcadores e desfechos clínicos}

\section{1 Ácidos Graxos Saturados (SFA)}

Durante as ultimas décadas, as recomendações médicas e nutricionais promoveram a mensagem de diminuição do consumo de ácidos graxos saturados. As recomendações foram indicadas tanto pela ação dos ácidos graxos saturados no aumento do LDL-C quanto no aumento do risco de doença cardiovascular, evidenciado pelos diversos estudos epidemiológicos ${ }^{50}$.

Discussões atuais questionam essas recomendações, pois, com a indicação de diminuição de gordura saturada, houve um aumento de consumo de outros nutrientes, tais como carboidratos $(\mathrm{CH})$ refinados. Evidências colhidas recentemente mostram que a substituição de gordura saturada por carboidratos simples pode ter grande impacto no aumento do risco de doença cardiovascular e diabetes ${ }^{50}$.

\subsection{Histórico de estudos SFA}

Entre os vários componentes dietéticos, são os ácidos graxos trans que mais aumentam LDL-C, seguido dos ácidos graxos saturados, que também aumentam HDL-c e não alteram a relação $\mathrm{CT} / \mathrm{HDL}$, se comparados ao consumo de carboidratos. O consumo de 1\% do VCT de SFA está associado com aumento de 1,3 a 1,7 mg/dL no LDL-c e 0,4 a 0,5 mg/dL de HDL-C $\mathrm{C}^{51-54}$.

Diferentes SFA podem ter efeitos diversos no perfil lipídico e fatores de risco cardiovascular. Metanálise recente ${ }^{55}$ mostrou que, se comparado a carboidratos, o ácido graxo láurico (C12:0) é o que mais aumenta o LDL-C, seguido do mirístico (C14:0) e do palmítico (C16:0). Já o esteárico pode provocar pequena redução no LDL-c. No tocante ao HDL-c, na mesma comparação com carboidratos, os AG láurico, mirístico e palmítico aumentam em maior \% o HDL-c, enquanto o esteárico provoca um pequeno aumento no $\mathrm{HDL}-\mathrm{C}^{55}$. O efeito dos ácidos graxos é comparado com outros nutrientes, no caso acima com carboidratos. Portanto, ao se analisar os efeitos desses AG, deve-se verificar qual nutriente foi substituído pelo AG em questão.
A substituição de SFA por carboidratos pode gerar efeitos controversos, pois depende do tipo de carboidrato; os carboidratos simples, refinados podem ocasionar efeitos neutros ou piores que os SFA. Os principais efeitos observados quando há troca de SFA por carboidratos são: diminuição Colesterol total, LDL-c e HDL-C, aumento TG, aumento da incidência de obesidade, diabetes, doença cardíaca e risco para síndrome metabólica. Parece não haver benefícios para diminuição do risco DCV ${ }^{50,56}$. O estudo Women's Health Initiative não mostrou associação entre substituição de SFA por carboidratos e risco de doença cardiovascular ${ }^{57,58}$. No entanto, uma metanálise ${ }^{59}$ mostrou que a substituição SFA por $\mathrm{CH}$ aumenta o risco de eventos coronarianos ${ }^{59}$.

A troca por SFA por monossaturados resulta na diminuição no LDL-C, mas também pode acarretar em diminuição do HDL-c (efeito menor que troca por poli) ${ }^{53}$.

A substituição por Ácido Graxo poli-insaturado (PUFA) é considerada a melhor escolha, pois pode ocasionar diminuição do LDL-c,aumento da razão HDL/LDL, diminuição da razão $\mathrm{CT} / \mathrm{HDL}$, redução de risco de DCV, segundo diretrizes da FDA e WHO $2009^{59}$ e pode provocar efeito benéfico na doença cardíaca isquêmica, no entanto pode levar a diminuição no HDL-C $50,52,53,56,60$.

Recentemente, Mozaffarian e cols. ${ }^{61}$ em Metanálise e anteriormente ${ }^{62,63}$ em estudos clínicos mostraram que a substituição de 5\% do VCT de SFA por PUFA ocasionou 10\% de redução de risco cardiovascular.

A concentração de LDL-c basal do indivíduo, condições preexistentes (obesidade, diabetes, resistência insulínica, hipertrigliceridemia e outras), além de fatores genéticos, podem influenciar na resposta ao SFA. Além disso, a composição de outros nutrientes do alimento também pode alterar a intensidade da resposta à ingesta de SFA ${ }^{56,64,65}$.

\subsection{Doença cardiovascular}

Os efeitos do ácido graxo saturado na prevenção de risco de doença cardiovascular são controversos.

Em metanálise ${ }^{56}$ observou-se evidência insuficiente que a ingesta de SFA aumenta risco DCV e acidente vascular encefálico (AVE). Já estudos com obesos mostraram que dieta rica em SFA e pobre em $\mathrm{CHO}$, em comparação com outras, foi considerada a mais benéfica, pois melhorou a razão $\mathrm{HDL} / \mathrm{LDL}^{66}$.

Em relação à hipertensão, em um estudo ${ }^{67}$ não foi verificada associação entre SFA e incidência de hipertensão arterial, após ajuste por idade, IMC e consumo de álcool. Já em outro estudo, o consumo de SFA foi associado positivamente com diminuição das pressões sistólica e diastólica ${ }^{68}$, mantendo a controvérsia sobre efeitos na aumento da pressão arterial.

As evidências parecem ser limitadas no que concerne ao efeito pró-inflamatório dos SFA ${ }^{55,69}$ e em relação ao efeito dos SFA na incidência de resistência insulínica e $\mathrm{DM}^{55}$.

Alguns estudos recentes mostram efeitos benéficos do consumo de $\mathrm{SFA}^{70}$, tais como: associação inversa dos SFA com progressão da aterosclerose coronariana em mulheres pós-menopausa e associação inversa de SFA com mortalidade por $\mathrm{AVE}^{71}$. 


\begin{tabular}{lcc}
\hline Recomendação & $\begin{array}{c}\text { Grau de } \\
\text { recomendação }\end{array}$ & $\begin{array}{c}\text { Nível de } \\
\text { evidência }\end{array}$ \\
\hline $\begin{array}{l}\text { O consumo de ácidos graxos saturados } \\
\text { além do recomendado está relacionado } \\
\text { com alteração no perfil lipídico (aumento } \\
\text { de LDL, aumento de HDL) }\end{array}$ & । & A \\
\hline $\begin{array}{l}\text { O consumo de ácidos graxos saturados } \\
\text { além do recomendado está relacionado } \\
\text { com aumento da pressão arterial }\end{array}$ & \|la & B \\
\hline $\begin{array}{l}\text { O consumo de ácidos graxos saturados } \\
\text { além do recomendado está relacionado } \\
\text { com desenvolvimento e/ou progressão de } \\
\text { diabetes mellitus tipo 2 e da obesidade }\end{array}$ & \|la & A \\
\hline $\begin{array}{l}\text { O consumo de ácidos graxos saturados } \\
\text { além do recomendado está relacionado } \\
\text { com aumento da inflamação }\end{array}$ & \|la & B \\
\hline $\begin{array}{l}\text { O consumo de ácidos graxos saturados } \\
\text { além do recomendado está relacionado } \\
\text { com aumento de eventos cardiovasculares }\end{array}$ & । & B \\
\hline $\begin{array}{l}\text { A substituição de SFA por carboidrato } \\
\text { simples pode ocasionar piora no perfil lipídico }\end{array}$ & III & B \\
\hline $\begin{array}{l}\text { A substituicãa de SFA por Ácidos Graxos } \\
\text { Monoinsaturados (MUFA) é recomendada } \\
\text { por ocasionar melhora no perfil lipídico }\end{array}$ & \|la & B \\
\hline $\begin{array}{l}\text { Asubstituição de SFA por PUFAé recomen- } \\
\text { dada por ocasionar melhora no perfil lipídico }\end{array}$ & \|la & B \\
\hline
\end{tabular}

\subsection{Recomendações de consumo de ácido graxo saturado (Tabela 1)}

\begin{tabular}{|c|c|c|}
\hline Recomendação & $\begin{array}{l}\text { Grau de } \\
\text { recomendação }\end{array}$ & $\begin{array}{l}\text { Nível de } \\
\text { evidência }\end{array}$ \\
\hline $\begin{array}{l}\text { Para adultos, o consumo de quantidades } \\
\text { menores que } 10 \% \text { do VET em ácidos } \\
\text { graxos saturados na alimentação está } \\
\text { relacionado a redução do LDL-c. }\end{array}$ & la & $A$ \\
\hline $\begin{array}{l}\text { A ingestão recomendada de ácidos } \\
\text { graxos saturados para adultos sem } \\
\text { comorbidades deve ser }<10 \% \text { do Valor } \\
\text { Energético Total (VET). }\end{array}$ & Ila & B \\
\hline $\begin{array}{l}\text { Indivíduos adultos que apresentam fatores } \\
\text { de risco associados a doença cardiovas- } \\
\text { cular como: hipertensão arterial sistêmica, } \\
\text { diabetes, sobrepeso ou obesidade, } \\
\text { circunferência da cintura aumentada*, } \\
\text { hipercolesterolemia, hipertrigliceridemia, } \\
\text { síndrome metabólica*, intolerância a glicose } \\
\text { ou aterosclerose significativa o consumo } \\
\text { deve ser }<7 \% \text { (VET) }\end{array}$ & la & A \\
\hline $\begin{array}{l}\text { Para crianças maiores de dois anos e } \\
\text { adolescentes e perfil lipídico normal } \\
\text { recomenda-se que a ingestão de } \\
\text { gordura esteja entre } 25 \% \text { e } 35 \% \text { (VET) } \\
\text { e }<10 \% \text { de ácidos graxos saturados }\end{array}$ & Ila & B \\
\hline $\begin{array}{l}\text { Para crianças maiores de dois anos e } \\
\text { adolescentes com perfil lipídico alterado, a } \\
\text { ingestão de gorduras deve se manter entre } \\
25 \% \text { e } 35 \% \text { para manutenção de ganho } \\
\text { de peso e para crescimento normal. A } \\
\text { recomendação de ácidos graxos saturados } \\
\text { deve, nesses casos, ser } 7 \% \text { do VET }\end{array}$ & la & $A$ \\
\hline $\begin{array}{l}\text { O consumo de ácidos graxos saturados } \\
\text { para gestantes com dislipidemia prévia } \\
\text { ou desenvolvida durante a gestação } \\
\text { dever ser limitado } a<7 \% \text {. }\end{array}$ & Ilc & $\mathrm{B}$ \\
\hline $\begin{array}{l}\text { A substituição de SFA por Ácidos Graxos } \\
\text { Monoinsaturados (MUFA) é recomendada } \\
\text { por ocasionar melhora no perfil lipídico }\end{array}$ & Ila & B \\
\hline $\begin{array}{l}\text { A substituição de SFA por PUFA é } \\
\text { recomendada por ocasionar melhora no } \\
\text { perfil lipídico }\end{array}$ & Ila & $B$ \\
\hline
\end{tabular}

Tabela 1 - Recomendação de ácidos graxos saturados (g) de acordo com a ingestão calórica

\begin{tabular}{ccc}
\hline VCT da dieta (Kcal) & $10 \% \mathrm{VCT}$ & $\mathbf{7 \%} \mathrm{VCT}$ \\
\hline 2000 & $22 \mathrm{~g}$ & $16 \mathrm{~g}$ \\
\hline 1800 & $20 \mathrm{~g}$ & $14 \mathrm{~g}$ \\
\hline 1500 & $17 \mathrm{~g}$ & $12 \mathrm{~g}$ \\
\hline 1200 & $13 \mathrm{~g}$ & $9 \mathrm{~g}$ \\
\hline
\end{tabular}

\subsection{Posicionamento sobre temas selecionados}

\subsubsection{Coco e óleo de coco}

O coco e o óleo de coco (Coco nucifera) são importantes fontes naturais de gorduras saturadas, especialmente de ácido láurico (C12:0). Em respeito à dislipidemia, sabe-se que gorduras sólidas saturadas ricas em ácido láurico resultam em perfil lipídico mais favorável do que uma gordura sólida rica em ácidos graxos trans ${ }^{53,72}$. Em relação aos demais tipos de gorduras saturadas, especialmente ácido mirístico e palmítico, o ácido láurico apresenta maior poder em elevar LDL-C, bem como HDL-C ${ }^{62}$. Entretanto, esse efeito parece não ser a causa do aumento da prevalência de DCV de acordo com estudos realizados na Ásia, onde o óleo de coco representa até $80 \%$ da gordura consumida em algumas regiões ${ }^{73,74}$.

No Brasil, um ensaio clínico mostrou redução da relação LDL:HDL, aumento do HDL-C e redução da circunferência abdominal no grupo que utilizou óleo de $\operatorname{coco}^{75}$. Apesar dos potenciais benefícios do óleo de coco no HDL, os estudos experimentais comprovam o efeito hipercolesterolêmico do coco e seus subprodutos, como o recente estudo com cobaias que comparou óleo de coco com azeite de oliva e óleo de girassol. O grupo tratado com óleo de coco apresentou aumento significativo da fração não HDL e triglicérides ${ }^{76}$.

\begin{tabular}{lcc}
\hline Recomendação & $\begin{array}{c}\text { Grau de } \\
\text { recomendação }\end{array}$ & $\begin{array}{c}\text { Nível de } \\
\text { evidência }\end{array}$ \\
\hline $\begin{array}{l}\text { Não se recomenda coco e óleo de coco } \\
\text { para tratamento de hipercolesterolemia, } \\
\text { sendo necessários estudos adicionais } \\
\text { para orientar seu uso em demais } \\
\text { alterações metabólicas }\end{array}$ & ।II & \\
\hline
\end{tabular}

\subsection{2 Óleo de palma}

Após o alerta sobre os malefícios do consumo de alimentos contendo gorduras trans, a indústria de alimentos encontrou no óleo de palma um substituto equivalente favorecendo a elevação do seu consumo nos últimos anos por meio dos alimentos industrializados. Além de apresentar baixo ponto de fusão, o óleo de palma apresenta grande resistência à oxidação em razão do elevado teor de ácidos graxos saturados, especialmente de ácido palmítico (cerca de $40 \%$ ). O perfil sanguíneo de ácidos graxos reflete a maior fonte de gordura consumida; dessa forma, dietas com alto teor de ácido palmítico elevam o teor desse tipo de gordura no sangue ${ }^{77}$.

Estudos em humanos e animais, que comparam o efeito metabólico de diferentes dietas, entre elas dieta com alto teor de óleo de palma, observaram aumento significativo de 
LDL-c e do colesterol total78-83. Em macacos, o óleo de palma foi fator desencadeador de aterosclerose em comparação ao óleo de cártamo ${ }^{84}$.

\begin{tabular}{lcc}
\hline Recomendação & $\begin{array}{c}\text { Grau de } \\
\text { recomendação }\end{array}$ & $\begin{array}{c}\text { Nível de } \\
\text { evidência }\end{array}$ \\
\hline $\begin{array}{l}\text { O consumo de óleo de palma ou de } \\
\text { alimentos contendo grande quantidade } \\
\text { desse óleo não é recomendado } \\
\text { para indivíduos com dislipidemia ou } \\
\text { na prevenção da dislipidemia e das } \\
\text { doenças cardiovasculares }\end{array}$ & $\|$ & \\
\hline
\end{tabular}

\subsubsection{Chocolate}

Originário da América do Sul, o chocolate é o produto obtido a partir da mistura de derivados de cacau (Theobromacacao L.), massa (ou pasta ou liquor) de cacau, cacau em pó e ou manteiga de cacau, com outros ingredientes. A gordura do chocolate, derivada do cacau, é constituída por dois ácidos graxos saturados, o ácido palmítico e o esteárico, e o ácido oleico monoinsaturado, em adição de uma pequena quantidade (menos do que 5\%) de outros ácidos graxos ${ }^{85,86}$.

Embora seja conhecido que o consumo de gorduras saturadas aumenta os níveis de colesterol, o consumo regular de manteiga de cacau e chocolate rico em cacau não se relaciona a esse aumento. As quantidades de ácido graxo esteárico são responsáveis pelo efeito neutro sobre o metabolismo do colesterol. Deve-se ter cuidado, no entanto, com chocolate confeccionado com leite, pois pode conter grande quantidade de ácidos graxos mirístico e láurico, conhecidamente hipercolesterolêmicos.

\begin{tabular}{lcc}
\hline Recomendação & $\begin{array}{c}\text { Grau de } \\
\text { recomendação }\end{array}$ & $\begin{array}{c}\text { Nível de } \\
\text { evidência }\end{array}$ \\
\hline $\begin{array}{l}\text { O consumo de chocolate rico em cacau } \\
\text { não está relacionado ao aumento do } \\
\text { colesterol }\end{array}$ & $\|$ & $\mathrm{C}$ \\
\hline
\end{tabular}

\subsubsection{Manteiga}

De acordo com a Portaria n 146, "com o nome de manteiga entende-se o produto gorduroso obtido exclusivamente pela bateção e malaxagem, com ou sem modificação biológica do creme pasteurizado derivado exclusivamente do leite de vaca, por processos tecnologicamente adequados. A matéria gorda da manteiga deverá estar composta exclusivamente de gordura láctea" ${ }^{17}$.

Richards $^{88}$ analisou a composição em ácidos graxos da manteiga e os predominantes foram: mirístico (14:0), palmítico (16:0), esteárico (18:0) e oleico (18:1). Os ésteres de colesterol constituem aproximadamente $10 \%$ dos esterois do leite.

Em estudos com indivíduos hipercolesterolêmicos e com síndrome metabólica ${ }^{77,89-91}$ que compararam diferentes tipos de margarina e manteiga, o valor de LDL-c manteve-se inalterado ou pouco aumentado após consumo de manteiga. No entanto, os estudos oferecem variadas quantidades de produto e o tempo de seguimento é variado, mantendo a controvérsia na literatura sobre a ação da manteiga nos lípides.

\begin{tabular}{lcc}
\hline Recomendação & $\begin{array}{c}\text { Grau de } \\
\text { recomendação }\end{array}$ & $\begin{array}{c}\text { Nível de } \\
\text { evidência }\end{array}$ \\
\hline $\begin{array}{l}\text { A relação do consumo de manteiga } \\
\text { e colesterolemia é controverso; } \\
\text { porém, de for moderado e dentro das } \\
\text { recomendações de gordura saturada, } \\
\text { poderá fazer parte da dieta }\end{array}$ & $\|$ & \\
\hline
\end{tabular}

\subsubsection{Carne}

As carnes habitualmente consumidas são importante fonte de proteínas de alto valor biológico, vitaminas do complexo $\mathrm{B}$ e, especialmente as carnes vermelhas, de ferro de ampla biodisponibilidade em comparação ao ferro presente em alimentos vegetais. No entanto, podem fornecer quantidades significativas de gorduras saturadas, especialmente ácido palmítico e, em menor proporção, ácido esteárico, em razão do tipo de animal, do tipo de criação do animal e da localização da carne (corte) ${ }^{92,93}$.

Os gráficos 1 e 2 mostram a quantidade de gordura saturada e colesterol e diferentes cortes de carne vermelha e de aves, respectivamente.

O valor do colesterol, independentemente do tipo de carne ou de preparo, não varia significativamente. O problema maior está no teor de gordura saturada ${ }^{94}$. Ao se preparar quaisquer tipos de carnes, é necessário que se remova a gordura aparente e a pele (aves), pois a gordura penetra no interior da carne durante o preparo. Entre os tipos de preparação, deve-se dar preferência ao grelhado, pois essa técnica evita a reabsorção da gordura pela carne ${ }^{95}$, além de preferir carne bem passada, pois a carne mal-passada com gordura apresenta as maiores taxas de gordura saturada e, portanto, deve ser evitada ${ }^{95}$. É importante destacar que para os alimentos cozidos a água utilizada no processo não deve ser reaproveitada, para que a gordura não seja reabsorvida ${ }^{94}$.

De acordo com a análise dos gráficos 3 e 4, concluiu-se que os altos teores de colesterol se concentram mais nas vísceras (no bucho e no fígado), no coração de frango e no camarão ${ }^{96}$.

É importante observar que o salmão possui um alto teor de gordura saturada se comparado com o namorado, porém possui uma quantidade significativa de gorduras insaturadas (gráfico 4).

De modo geral, estudos que analisaram o impacto de planos alimentares com consumo controlado de carne vermelha indicaram redução da pressão arterial e menor risco de mortalidade por doenças cardiovasculares ${ }^{97}$. Grupos vegetarianos também apresentam menores níveis de colesterol sanguíneo quando comparados a onívoros ${ }^{97}$.

\begin{tabular}{lcc}
\hline \multicolumn{1}{c}{ Recomendação } & $\begin{array}{c}\text { Grau de } \\
\text { recomendação }\end{array}$ & $\begin{array}{c}\text { Nível de } \\
\text { evidência }\end{array}$ \\
\hline $\begin{array}{l}\text { Recomenda-se consumo controlado } \\
\text { de carne vermelha, miúdos e aves } \\
\text { com pele, além da restrição de cortes } \\
\text { gordurosos. Deve-se observar o modo } \\
\text { de preparo para minimizar o consumo } \\
\text { de gordura saturada }\end{array}$ & $\|$ & \\
\hline
\end{tabular}




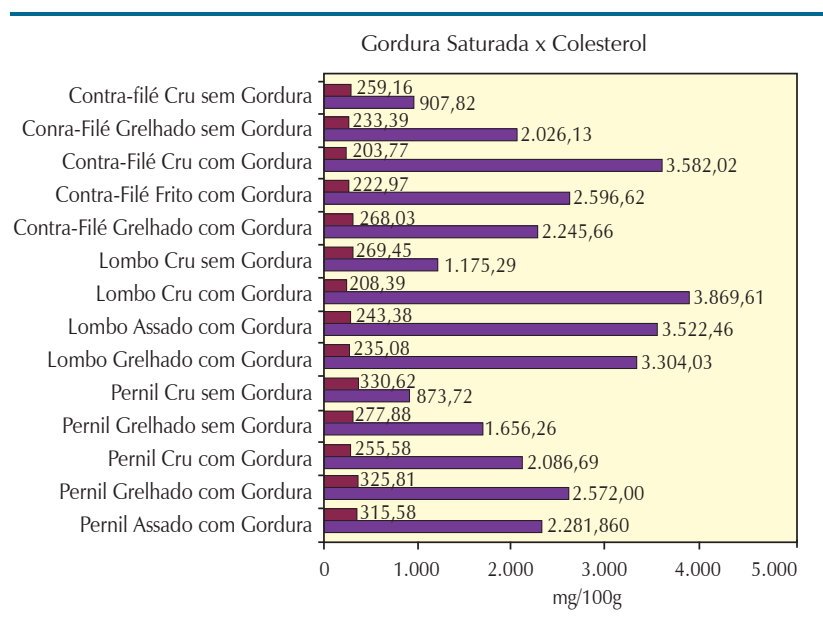

Gordura Saturada $\square$ Colesterol

Gráfico 1 - Quantidade de gordura saturada e colesterol e diferentes cortes de carne vermelha. Fonte: Inmetro, $2001^{98}$.

Colesterol (mg/100g) X Gordura Saturada (mg/100g)

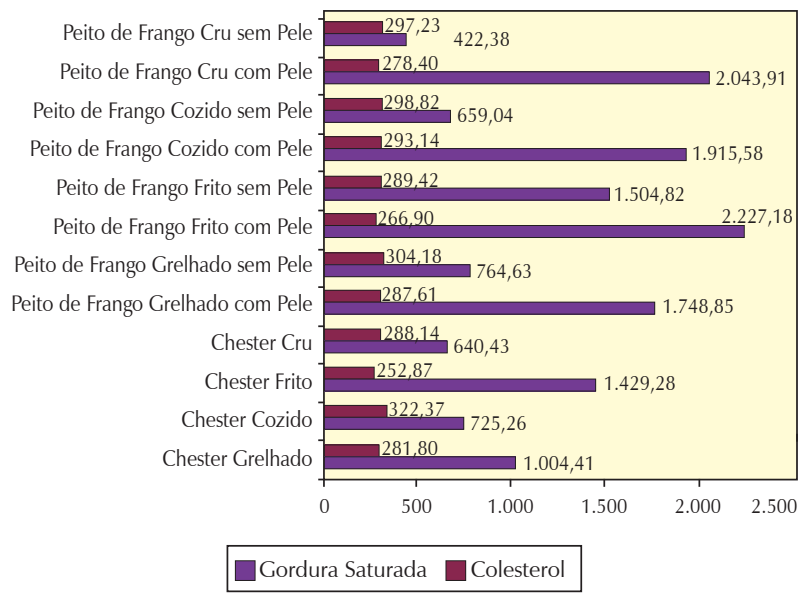

Gráfico 2 - Valores de colesterol e gordura saturada de diferentes cortes e preparações de aves. Fonte: Inmetro, $2001^{98}$.

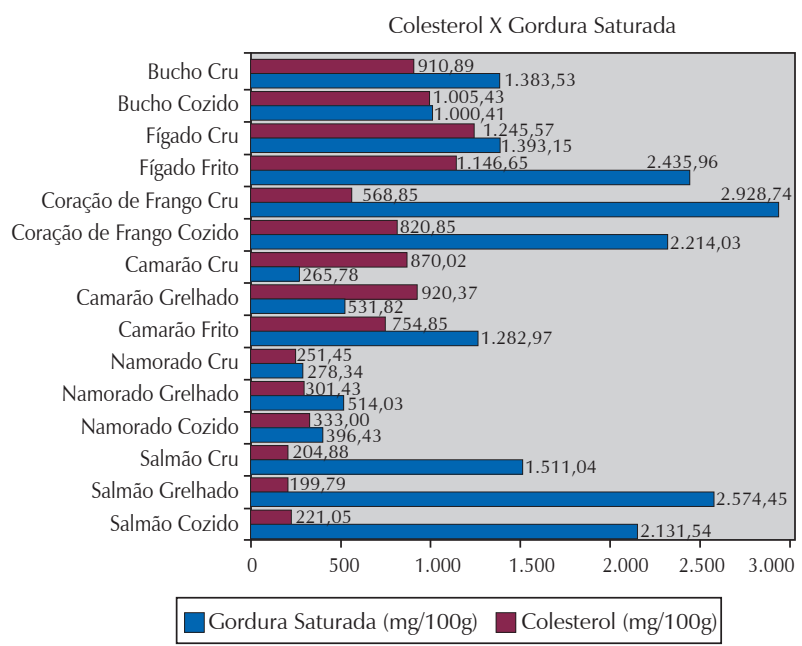

Gráfico 3 - Valores de colesterol e gordura saturada de diferentes preparações de miúdos, frutos do mar e peixes. Fonte: Inmetro, $2001^{98}$.

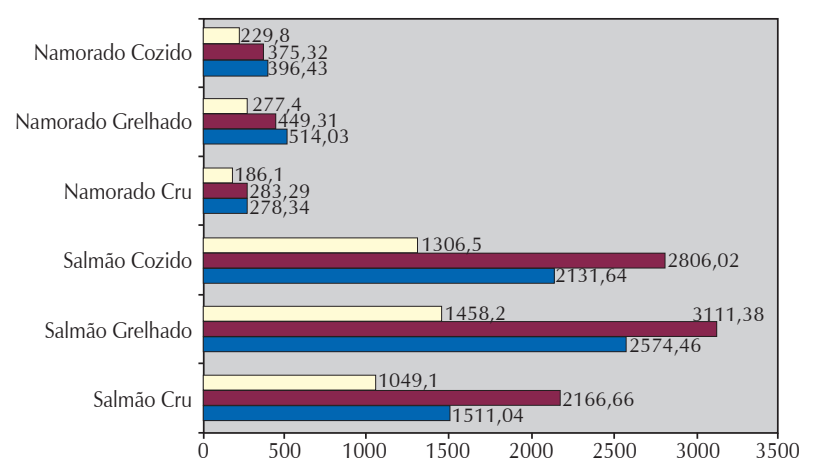

$\square$ Gordura Saturada (mg/100g) $\square$ Gordura Insaturada (mg/100g) $\square$ Ômega 3 (mg/100g)

Gráfico 4 - Valores de gordura saturada, insaturada e Ômega-3 de diferentes preparações de peixes. Fonte: Inmetro, $2001^{98}$.

\subsubsection{Queijos}

O queijo é um alimento sólido fabricado a partir do leite de vaca, cabra, ovelha, búfala e/ou outros mamíferos, sendo um concentrado lácteo constituído de proteínas, lipídios, carboidratos, minerais, cálcio, fósforo e vitaminas (especialmente A, B2, B9, B12 e D).

A crença popular de que queijos de cor branca são adequados à saúde cardiovascular merece ser revista. O leite integral apresenta elevado teor de gorduras saturadas, especialmente ácido palmítico e mirístico. Dessa forma, qualquer queijo cujo principal ingrediente seja o leite integral será semelhante fonte de gorduras saturadas.

O gráfico 5 mostra a quantidade de gordura saturada de alguns tipos de queijo amplamente consumidos. Observa-se que queijos mais amarelos, como parmesão e minas padrão, contêm grandes quantidades de gordura saturada. Da mesma forma, a versão light de alguns produtos pode conter menor quantidade dessa gordura. O consumo excessivo de queijos como minas frescal, requeijão cremoso, creme de queijo comum (cream cheese), creme de queijo light (cream cheese light) entre outros queijos de cor branca pode representar risco à dieta pobre em gorduras saturadas. Recomenda-se controlar o tamanho das porções consumidas ${ }^{99}$.

A tabela 2 traz as equivalências em medida caseira referente a uma porção de $30 \mathrm{~g}$ de produto. Sugere-se que adequações individuais na dieta sejam feitas por nutricionista para que alcancem as recomendações de cálcio ${ }^{99}$.

\begin{tabular}{lcc}
\hline Recomendação & $\begin{array}{c}\text { Grau de } \\
\text { recomendação }\end{array}$ & $\begin{array}{c}\text { Nível de } \\
\text { evidência }\end{array}$ \\
\hline $\begin{array}{l}\text { O consumo de queijo deve ser feito com } \\
\text { cautela, dando-se preferência para queijos } \\
\text { com menor teor de gordura saturada. }\end{array}$ & \\
$\begin{array}{l}\text { O consumidor deve observar nas } \\
\text { embalagens o teor dessa gordura e evitar } \\
\text { o consumo irrestrito de queijos brancos }\end{array}$ & & \\
\hline
\end{tabular}

Tabela 2 - Medida caseira e conteúdo de gordura saturada em $30 \mathrm{~g}$ de queijos selecionados

\begin{tabular}{llc}
\hline Produto & Medida caseira & Gordura saturada (g) \\
\hline Queijo minas frescal & $\begin{array}{l}\text { 1 fatia pequena } \\
(7 \times 7 \times 0,5 \mathrm{~cm})\end{array}$ & 3,4 \\
\hline Requeijão cremoso & 1 colher de sopa & 4,1 \\
\hline Creme de queijo & 1 colher de sopa & 5,1 \\
\hline Creme de queijo light & 1 colher de sopa & 3,5 \\
\hline
\end{tabular}

Fonte: TACO. Tabela brasileira de composição de alimentos / Nepa-Unicamp. -Versão II. 2.ed. Campinas: Nepa-Unicamp, $2006^{99}$. 


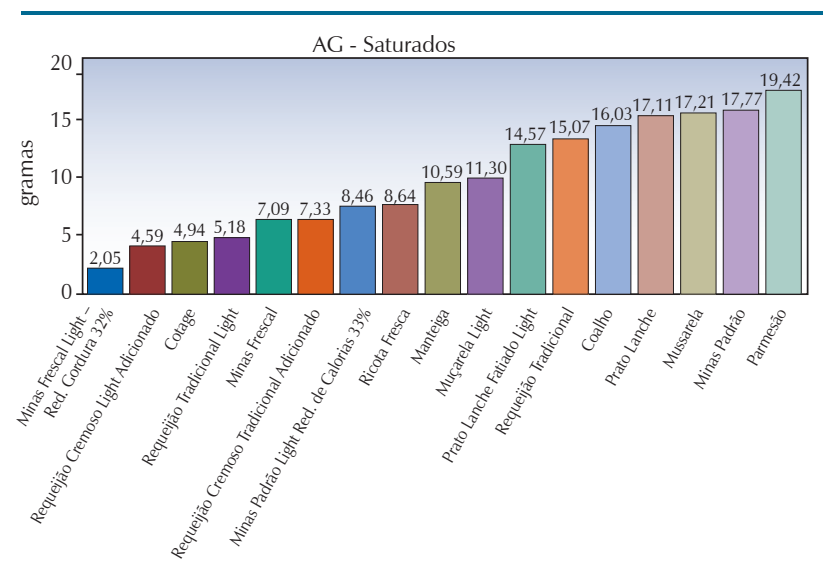

Gráfico 5 - Quantidade de ácidos graxos saturados por tipo de queijo. Fonte: Inmetro, $2011^{98}$.

\section{Efeitos e recomendações do consumo dos ácidos graxos monoinsaturados sobre mecanismos fisiopatológicos do processo aterosclerótico: biomarcadores e desfechos clínicos}

\section{1 Ácidos Graxos Monoinsaturados (MUFA)}

\subsubsection{Efeitos sobre o metabolismo lipídico}

Quando comparada a dieta hipogordurosa (NCEP Step II) ou a dietas pobres em gorduras, mas ricas em carboidratos, a dieta rica em MUFA proporciona efeitos mais favoráveis sobre os níveis de triglicérides e HDL-c, para o mesmo grau de redução da colesterolemia ${ }^{100-102}$.

Com relação à dieta do Mediterrâneo, rica em MUFA, uma revisão sistemática e Metanálise de estudos epidemiológicos e ensaios randomizados controlados mostrou que a aderência a esse padrão dietético associa-se a modificações discretas do HDL-c (aumento de 1,17 mg/dL) e triglicérides (redução de $6,14 \mathrm{mg} / \mathrm{dL})^{103}$.

Existem também evidências de uma relação entre tipo de gordura consumida e características qualitativas da LDL. Pela presença de ligações duplas, os ácidos insaturados são particularmente suscetíveis a modificação oxidativa. Estudos demonstram que dietas contendo MUFA em substituição ao PUFA tornam a LDL menos suscetível à oxidação ${ }^{104,105}$, o que pode resultar, em teoria, em inibição do processo aterogênico, já que é amplamente aceito que a molécula de LDL oxidada tem relevante papel na inflamação vascular, na disfunção do endotélio e na formação de células espumosas na parede intimal.

\subsubsection{Efeitos sobre o metabolismo glicídico}

Há evidências fisiopatológicas de um efeito positivo dos MUFA sobre diversos mecanismos envolvidos na etiopatogenia do diabetes tipo 2. Estudos mecanísticos em humanos demonstram que intervenções de curto prazo, com substituição de PUFA por MUFA, ou o simples aumento do consumo de MUFA, pode acarretar melhoras na resistência a insulina ${ }^{106}$, resposta da célula beta na produção de insulina ${ }^{107}$, aumento da resposta de produção de incretinas (aumento de GLP-1 $)^{108}$ e redução do clearance de insulina ${ }^{109}$.

No Nurses' Health Study, o consumo de castanhas, uma importante fonte de PUFA e MUFA nessa população, foi associado a um risco reduzido de desenvolver diabetes, após ajustes para o consumo de fibras e diversos fatores relacionados ao estilo de vida ${ }^{110}$.

Não existem estudos randomizados controlados de longo prazo em relação à qualidade das gorduras dietéticas e o risco de desenvolver diabetes. Dessa forma, os conceitos vigentes se baseiam em estudos de curto prazo tendo como desfechos a mudança de indicadores relacionados à fisiopatologia do diabetes. Os dados disponíveis de estudos de intervenção sugerem, em geral, efeitos benéficos sobre a sensibilidade a insulina quando SFA e TFA são substituídos por MUFA ou PUFA ${ }^{111}$.

O estudo multicêntrico KANWU foi o maior ensaio randomizado controlado sobre diferentes intervenções dietéticas com diferentes fontes de ácidos graxos ${ }^{112}$. Os voluntários ( $\mathrm{n}=162$ ) receberam dietas isocalóricas que diferiram apenas no conteúdo de gorduras. O principal achado foi demonstrar que a substituição de SFA por MUFA promoveu uma melhora da sensibilidade a insulina. A substituição isocalórica de carboidratos por MUFA também melhora a sensibilidade a insulina ${ }^{113}$.

Outros estudos de menor porte corroboram a hipótese de que o consumo de MUFA pode exercer efeitos benéficos sobre a resistência a insulina ${ }^{107,114}$, enquanto outras investigações mostraram poucas mudanças na sensibilidade a insulina induzidas por PUFA ou MUFA em indivíduos com intolerância a glicose ${ }^{115}$ e diabetes tipo 2116, embora tenham ocorrido mudanças significativas na composição de ácidos graxos plasmáticos.

No que diz respeito à dieta do Mediterrâneo, numa revisão sistemática e Metanálise envolvendo mais de 500 mil indivíduos, a aderência a esse padrão de dieta associou-se a pequena redução da glicemia $(3,89 \mathrm{mg} / \mathrm{dL})$ e diminuição de $31 \%$ no risco de síndrome metabólica ${ }^{103}$.

\subsubsection{Efeitos sobre a pressão arterial}

Estudos epidemiológicos demonstram relações distintas entre o tipo de gordura ingerida e mudanças na pressão arterial (tab. 3). Modificações nas proporções das gorduras, com redução de SFA e aumento de MUFA, podem colaborar para uma redução da pressão arterial ${ }^{117}$. No entanto, esse efeito benéfico pode ser anulado se a gordura total consumida for excessiva ${ }^{118}$.

Estudos de intervenção mostram que os MUFA de fontes vegetais, especialmente quando parte da dieta do Mediterrâneo, podem diminuir discretamente a pressão arterial e possivelmente desempenham um papel relevante na prevenção da hipertensão arterial ${ }^{117}$. Em um desses estudos, Appel e cols. ${ }^{126}$ encontraram uma redução da pressão sistólica de 1,3 mmHg em indivíduos sem hipertensão, quando comparada a uma dieta rica em carboidrato, e de 2,9 $\mathrm{mmHg}$ entre os hipertensos. Esses resultados são corroborados por uma revisão sistemática e Metanálise que sugere que a aderência à dieta do Mediterrâneo associa-se a um efeito favorável sobre a pressão arterial ${ }^{103}$. 
Tabela 3 - Estudos que analisaram a relação entre o consumo de gordura monoinsaturada e óleo de oliva e a pressão arterial

\begin{tabular}{|c|c|c|c|c|}
\hline Estudo & País & Delineamento do estudo & População estudada & Principais resultados \\
\hline Nurses' Health Study ${ }^{119,120}$ & EUA & Coorte & $\begin{array}{l}58.218 \text { mulheres, } \\
\text { 34-79 anos }\end{array}$ & $\begin{array}{l}\text { Sem efeito no surgimento } \\
\text { de HAS }\end{array}$ \\
\hline Health Professionals' Follow-up Study ${ }^{67}$ & EUA & Coorte & $\begin{array}{l}30.681 \text { homens, } \\
40-75 \text { anos }\end{array}$ & Sem efeito no risco de HAS \\
\hline $\begin{array}{l}\text { Chicago Western Electric Company } \\
\text { Study }{ }^{121}\end{array}$ & EUA & Coorte & $\begin{array}{l}1.714 \text { homens, } \\
40-55 \text { anos }\end{array}$ & MUFA associado com $\uparrow$ da PA \\
\hline Multiple Risk Factor Intervention Trial ${ }^{68}$ & EUA & Coorte & $\begin{array}{l}11.342 \text { homens, } \\
35-57 \text { anos }\end{array}$ & Sem efeito na PA \\
\hline Willians e cols. ${ }^{122}$ & EUA & Estudo cruzado & $\begin{array}{l}76 \text { homens, } \\
30-55 \text { anos }\end{array}$ & $\begin{array}{c}\text { Relação inversa entre MUFA } \\
\text { e PA }\end{array}$ \\
\hline Italian Nine Communities Study ${ }^{123}$ & Itália & Estudo cruzado & $\begin{array}{l}4.903 \text { mulheres, } \\
20-59 \text { anos }\end{array}$ & $\begin{array}{l}\text { Consumo de óleo de oliva } \\
\text { associado a } \downarrow \text { PA }\end{array}$ \\
\hline EPIC-Greece ${ }^{124}$ & Grécia & Estudo cruzado & $\begin{array}{c}20.343 \text { mulheres, } \\
\text { 20-86 anos }\end{array}$ & $\begin{array}{c}\text { Óleo de oliva e razão MUFA/ } \\
\text { SFA associados inversamente } \\
\text { com PA }\end{array}$ \\
\hline SUN Study ${ }^{125}$ & Espanha & Coorte & $\begin{array}{l}6.863 \text { ambos } \\
\text { os sexos }\end{array}$ & $\begin{array}{c}\text { Óleo de oliva associado a } \downarrow \text { PA } \\
\text { em homens apenas }\end{array}$ \\
\hline
\end{tabular}

HAS: hipertensão arterial sistêmica; PA: pressão arterial.

Adaptado de: Rasmussen e cols. ${ }^{118}$.

\subsubsection{Outros efeitos sobre mecanismos relacionados} à aterotrombose

O uso de MUFA está relacionado a melhorias da função endotelial e da adesão monocitária, além de reduções de marcadores inflamatórios e agregação plaquetária ${ }^{127}$. Uma parte desses efeitos foi evidenciada com o uso específico de óleo de oliva, incluindo proteção contra trombogênese e estresse oxidativo ${ }^{128,129}$

\subsubsection{Efeitos sobre eventos cardiovasculares}

Vários estudos observacionais de larga escala indicam uma associação entre consumo de MUFA e redução de risco cardiovascular (tab. 4) 47,130-132. Apenas um estudo, com betacaroteno e alfatocoferol em fumantes, falhou em demonstrar esse achado ${ }^{132}$.
Em uma análise de estudos de coorte prospectivos e ensaios randomizados investigando a relação entre exposição a diferentes padrões dietéticos e eventos coronarianos, tanto o consumo de MUFA como a aderência à dieta do Mediterrâneo mostraram-se associados a menor risco de doença arterial coronariana, e o papel protetor da dieta mediterrânea foi observado até mesmo nos estudos clínicos randomizados ${ }^{133}$.

\subsection{Recomendações}

Com base nas considerações aqui expostas, pode-se dizer que existe um conjunto de evidências a favor dos benefícios dos MUFA para um melhor controle dos fatores de risco tradicionais para a doença cardiovascular aterosclerótica. A melhor evidência nesse sentido se faz para os efeitos hipocolesterolêmicos quando os MUFA substituem os SFA.

Tabela 4 - Estudos que analisaram a relação entre consumo de MUFA e óleo de oliva e desfechos cardiovasculares

\begin{tabular}{|c|c|c|c|}
\hline Estudo & Tipo de estudo & População & Resultado \\
\hline Seven Countries Study ${ }^{130}$ & $\begin{array}{l}\text { Populacional } \\
\text { transversal }\end{array}$ & 12.770 homens & $\begin{array}{l}\text { Baixo risco de morte CV relacionado ao consumo de } \\
\text { grandes quantidades de óleo de oliva }\end{array}$ \\
\hline Nurse's Health Study ${ }^{47}$ & $\begin{array}{l}\text { Populacional } \\
\text { prospectivo }\end{array}$ & 80.082 mulheres & $\begin{array}{l}\text { Associação entre aumento de consumo proporcional } \\
\text { de MUFA e menor risco relativo de morte CV }\end{array}$ \\
\hline $\begin{array}{l}\text { Coronary Mortality in France and } \\
\text { Finland }{ }^{131}\end{array}$ & Epidemiológico & Não aplicável & $\begin{array}{l}\text { Associação entre consumo absoluto de MUFA e menor } \\
\text { RR de morte CV }\end{array}$ \\
\hline $\begin{array}{l}\text { The Alpha-Tocopherol Beta-Carotene } \\
\text { Cancer Prevention Study }{ }^{132}\end{array}$ & Coorte prospectivo & 21.930 fumantes & $\begin{array}{c}\text { Nenhuma associação entre MUFA e risco de } \\
\text { doença CV }\end{array}$ \\
\hline
\end{tabular}

$C V$ : cardiovascular; $R R$ : risco relativo

Adaptado de: Am Fam Physician. 2009;80(4):345-350, 372. 
É importante enfatizar, no entanto, que ainda há limitações para a recomendação do consumo de MUFA para prevenção de DM e HAS pela falta de estudos randomizados e controlados em longo prazo.

Além disso, existem evidências de que o consumo de MUFA dentro do contexto da dieta do Mediterrâneo associase à redução do risco de eventos $\mathrm{CV}$ e mortalidade.

Dessa forma, a Tabela 5 traz as recomendações baseadas nas melhores evidências do momento.

Tabela 5 - Recomendações para consumo de produtos ricos em MUFA

\begin{tabular}{lcc}
\hline Recomendação & $\begin{array}{c}\text { Grau de } \\
\text { recomendação }\end{array}$ & $\begin{array}{c}\text { Nível de } \\
\text { evidência }\end{array}$ \\
\hline $\begin{array}{l}\text { Substituir ácidos graxos saturados da } \\
\text { dieta por MUFA deve ser recomendado } \\
\text { para otimizar a redução dos níveis } \\
\text { plasmáticos de LDL-c. }\end{array}$ & A & \\
\hline $\begin{array}{l}\text { Substituir ácidos graxos saturados da } \\
\text { dieta por MUFA pode ser recomendado } \\
\text { para melhorar a sensibilidade a insulina e } \\
\text { reduzir o risco de diabetes mellitus. }\end{array}$ & \|la & B \\
\hline $\begin{array}{l}\text { Substituir ácidos graxos saturados da dieta } \\
\text { por MUFA pode ser recomendado para } \\
\text { melhorar o controle da pressão arterial. }\end{array}$ & \|la & B \\
\hline $\begin{array}{l}\text { Substituir ácidos graxos saturados da } \\
\text { dieta por MUFA, perfazendo 15\% da } \\
\text { energia total, pode ser recomendado para } \\
\text { reduzir o risco cardiovascular. }\end{array}$ & lla & A \\
\hline
\end{tabular}

MUFA: Ácido graxo monoinsaturado.

\section{Efeitos e recomendações do consumo dos ácidos graxos poli-insaturados sobre mecanismos fisiopatológicos do processo aterosclerótico: biomarcadores e desfechos clínicos}

\section{1. Ácidos graxos poli-insaturados (PUFA)}

\section{2. Ácidos graxos poli-insaturados Ômega-3 de origem} marinha (Docosaexaenoico (DHA) e eicosapentaenoico (EPA))

Os ácidos graxos Ômega-3 de origem marinha, ácido docosaexaenoico (DHA) e ácido eicosapentaenoico (EPA), exercem inúmeros efeitos sobre diferentes aspectos fisiológicos e do metabolismo que podem influenciar a chance de desenvolvimento de doenças cardiovasculares. Embora seja consensual que o consumo regular de peixes ricos em ácido graxo Ômega-3 faça parte de uma dieta saudável, a recomendação de suplementar a dieta com cápsulas de óleo de peixe cerca-se por controvérsias, fomentadas por resultados conflitantes de estudos clínicos.

\subsubsection{Efeitos sobre o metabolismo lipídico}

Estudos clínicos mostram que a suplementação com 2 a 4 g de EPA/DHA ao dia pode diminuir os níveis de triglicérides (TG) em até 25\% a 30\%, aumentar discretamente os de HDL- colesterol (1\% a 3\%) e elevar os de LDL-colesterol em até 5\% a $10 \%{ }^{134-136}$.

A capacidade de reduzir os níveis de TG depende da dose, com uma redução aproximada de $5 \%$ a $10 \%$ para cada $1 \mathrm{~g}$ de EPA/DHA consumido ao dia ${ }^{137}$, e é maior nos indivíduos com níveis basais mais elevados de $\mathrm{TG}^{138}$.

\subsubsection{Efeitos sobre o metabolismo glicídico}

Estudos de coorte prospectivos envolvendo um grande número de participantes sugerem que o maior consumo de ácido graxo Ômega-3 associa-se a maior incidência de Diabetes Mellitus (DM) $)^{139,140}$. No entanto, tal associação não é consistente ${ }^{141}$, havendo até mesmo evidências de que concentrações plasmáticas mais elevadas de EPA/DHA possam se associar a menor chance de novos casos de diabetes ${ }^{142}$.

Além disso, uma Metanálise de 23 estudos clínicos randomizados não evidenciou alterações significativas de hemoglobina glicada, glicemia de jejum ou insulina de jejum quando ácido graxo Ômega-3 (dose média 3,5 g/dia) foi suplementado a indivíduos diabéticos ${ }^{136}$. De forma semelhante, outra Metanálise de 26 ensaios clínicos constatou que a suplementação com óleo de peixe (2-22 g/dia) não alterou os níveis de hemoglobina glicada em pacientes diabéticos ${ }^{143}$.

\subsubsection{Efeitos sobre a pressão arterial}

Em uma Metanálise de 36 ensaios clínicos randomizados, a suplementação com óleo de peixe (dose mediana 3,7 g/dia) mostrou reduzir a pressão arterial sistólica em 3,5 mmHg e a diastólica em 2,4 mmHg ${ }^{144}$. Redução de tônus adrenérgico e da resistência vascular sistêmica são mecanismos propostos ${ }^{145}$.

\subsubsection{Efeitos sobre a inflamação}

Sendo precursores de eicosanóides e outros mediadores anti-inflamatórios, os ácidos graxos Ômega-3 poderiam proporcionar efeitos anti-inflamatórios, com possíveis benefícios para inúmeras condições patológicas, incluindo as cardiovasculares. Vários estudos experimentais têm mostrado uma gama de efeitos anti-inflamatórios dos ácidos graxos Ômega-3, embora as investigações in vivo, em humanos, tenham mostrado resultados conflitantes ${ }^{146,147}$.

Em alguns estudos transversais e de coorte, o consumo de ácido graxo Ômega-3 marinho pela dieta associou-se a menores níveis plasmáticos de marcadores inflamatórios, incluindo moléculas de adesão e Proteína C-Reativa (PCR) ${ }^{148,149}$.

De forma concordante, níveis de Ômega-3 marinho no plasma e em membranas de eritrócito ou granulócito associaram-se inversamente aos níveis de PCR em indivíduos saudáveis ou com doença arterial coronariana estável ${ }^{150-152}$.

Em estudos de intervenção de pequeno porte, alimentação rica em Ômega-3 marinho e suplementação com óleo de peixe ou DHA mostraram resultados compatíveis com uma atenuação da resposta inflamatória em indivíduos com diabetes e hipertrigliceridêmicos ${ }^{153-155}$.

Em outros ensaios, a dieta suplementada com Ômega-3 não provocou alterações significativas em parâmetros inflamatórios em indivíduos com síndrome metabólica $(1,24 \mathrm{~g} / \mathrm{dia})^{156}$ 
e pacientes com infarto do miocárdio prévio $(5,2 \mathrm{~g} / \mathrm{dia})^{157}$, o mesmo ocorrendo com a suplementação com ácidos graxos poli-insaturados sobre os níveis de PCR em indivíduos saudáveis $(2,0 \text { ou } 6,6 \mathrm{~g} / \text { dia })^{158}$.

Obviamente, diferenças na metodologia (perfil da população, forma e dose de suplementação e parâmetros analisados) podem ter contribuído para essas discrepâncias de resultados. Portanto, a real relevância clínica dos efeitos anti-inflamatórios dos ácidos graxos Ômega-3 de origem marinha é ainda incerta.

\subsubsection{Efeitos sobre a função endotelial}

A disfunção do endotélio está intimamente associada à inflamação da parede vascular. Assim como ocorre para os efeitos da suplementação com ácido graxo Ômega-3 marinho sobre a resposta inflamatória, os efeitos sobre a função endotelial in vivo, em humanos, são controversos. Uma análise recente de 33 ensaios de intervenção sugere que os ácidos graxos Ômega-3 de origem marinha podem melhorar a função endotelial em sujeitos dislipidêmicos com sobrepeso e em diabéticos, embora os resultados sejam conflitantes em pacientes com doença cardiovascular e inconsistentes em indivíduos saudáveis ${ }^{159}$.

\subsubsection{Efeitos sobre a aterosclerose}

Em modelos de aterosclerose em camundongos, vários estudos relatam que óleo de peixe e EPA atenuam o processo aterosclerótico ${ }^{160-164}$, embora isso não tenha ocorrido em outras condições experimentais ${ }^{161,165}$.

Alguns estudos populacionais sugerem uma associação inversa entre consumo de peixe ou ácido graxo Ômega-3 de cadeia longa/marinho e marcadores de aterosclerose subclínica, como espessura médio-intimal de carótida e calcificação coronariana, embora tal relação pareça ser fraca e não consistente ${ }^{166-168}$.

Em um ensaio randomizado com pacientes com doença arterial coronariana, a suplementação com aproximadamente 1,5 g/dia de ácido graxo Ômega-3 por dois anos provocou menos progressão e mais regressão da aterosclerose coronariana, medida por angiografia invasiva quantitativa, em relação ao uso de placebo, embora as diferenças tenham sido pequenas ${ }^{169}$. Nesse mesmo estudo, todavia, a suplementação não modificou a evolução da aterosclerose carotídea avaliada por ultrassonografia ${ }^{170}$, o que contrasta com os resultados de outro estudo randomizado no qual EPA altamente purificado (1,8 g/dia) mostrou atenuar a progressão do espessamento médio-intimal de carótida em diabéticos ${ }^{171}$.

É possível também que o ácido graxo Ômega-3 exerça papel protetor de eventos cardiovasculares através da modulação das características da placa aterosclerótica, tornando-a mais estável. Em um estudo randomizado de pacientes aguardando endarterectomia de carótida, a suplementação com óleo de peixe mostrou que os Ômega-3 rapidamente se incorporam na placa aterosclerótica e podem induzir modificações compatíveis com um perfil menos vulnerável a fenômenos de ruptura e instabilização ${ }^{172}$, observação consistente com achados experimentais ${ }^{164}$.

\subsubsection{Efeitos antiarrítmicos}

Vários estudos experimentais mostraram efeitos antiarrítmicos dos ácidos graxos Ômega-3, atribuídos especialmente a um efeito direto sobre canais iônicos ${ }^{147}$. Outros mecanismos relatados incluem modulação do tônus autonômico (melhora da variabilidade da frequência cardíaca), redução da frequência cardíaca basal e limitação da arritmia de reperfusão ${ }^{147}$. Esses efeitos podem explicar os resultados benéficos dos ácidos graxos Ômega-3 sobre a prevenção de morte súbita observada em alguns estudos (Tabela 6 e 7).

\subsubsection{Efeitos sobre eventos cardiovasculares}

As tabelas 6 e 7 resumem os achados dos principais estudos clínicos que avaliaram o efeito de peixe ou ácido graxo Ômega-3 marinho, seja da dieta, seja na forma de suplementação, sobre desfechos cardiovasculares.

Apesar de várias evidências antigas sugerirem efeito protetor de peixes e dos ácidos graxos Ômega-3 de origem marinha sobre eventos cardiovasculares, sobretudo em indivíduos que já apresentavam doença cardiovascular, os estudos mais recentes não mostraram benefícios da suplementação com Ômega-3 em sujeitos que já haviam apresentado manifestações de doença aterosclerótica ${ }^{179-181}$.

Uma das possíveis razões relaciona-se com o perfil da população estudada, especialmente no que se refere ao uso mais frequente de medicamentos sabidamente protetores (exemplo: estatinas, betabloqueadores, inibidores da enzima de conversão da angiotensina), ao controle mais agressivo dos fatores de risco tradicionais, e ao maior número de procedimentos de revascularização nos estudos mais contemporâneos. Dessa forma, questiona-se se os ácidos graxos Ômega-3 podem trazer reais benefícios adicionais quando o paciente é manejado de acordo com as recomendações atuais.

Questões envolvendo forma, dose e tempo de suplementação também podem ser levantadas. Por exemplo, nos estudos Alpha Omega ${ }^{179}$ e SU.FOL.OM3 ${ }^{181}$, a dose de $\mathrm{EPA}+\mathrm{DHA}$ (400-600 mg/dia) pode ter sido insuficiente para se observar benefício clínico.

\subsubsection{Eventos arrítmicos e morte súbita}

Vários estudos observacionais sugeriram que os ácidos graxos Ômega-3 podem exercer uma proteção particular contra morte súbita, sobretudo nos pacientes vitimados por infarto do miocárdio. Esse efeito benéfico foi também verificado numa subanálise do ensaio randomizado GISSI-Prevenzione ${ }^{189}$, mas não no mais recente, $\mathrm{OMEGA}^{180}$ (Tabela 6).

Essa hipótese também foi verificada em pacientes portadores de cardiodesfibrilador implantável. Os resultados foram inconsistentes, sugerindo desde um discreto efeito benéfico dos ácidos graxos Ômega-3 na redução de arritmias ventriculares graves nesse subgrupo de pacientes ${ }^{190}$, até ensaio sugerindo um efeito pró-arrítmico em alguns pacientes ${ }^{191}$. 


\section{Diretrizes}

\begin{tabular}{|c|c|c|c|c|}
\hline Estudo & População & Intervenção & Seguimento & Resultado \\
\hline $\mathrm{DART}^{173}$ & 2.033 homens pós-IAM & $\begin{array}{l}\text { Aconselhamento } \\
\text { dietético }\end{array}$ & 2 anos & $\begin{array}{c}\text { Consumo de 2-3 porções de peixe por semana reduziu significativamente } \\
\text { a mortalidade total em } 29 \% .\end{array}$ \\
\hline $\begin{array}{l}\text { GISSI } \\
\text { Prevenzione }{ }^{174}\end{array}$ & $\begin{array}{l}11324 \text { indivíduos com } \\
\text { IAM recente ( } \leq 3 \text { meses) }\end{array}$ & $\begin{array}{l}\text { Ômega-3 (1 g/dia), } \\
\text { vitamina } E \text {, ambos ou } \\
\text { nada }\end{array}$ & 3,5 anos & $\begin{array}{l}\text { Ômega-3 reduziu significativamente o risco de morte e doença } \\
\text { cardiovascular. }\end{array}$ \\
\hline DART-2 ${ }^{175}$ & $\begin{array}{l}3114 \text { homens }<70 \\
\text { anos com angina }\end{array}$ & $\begin{array}{l}\text { Aconselhamento } \\
\text { dietético }\end{array}$ & $3-9$ anos & $\begin{array}{l}\text { Aumento do risco de morte cardiaca e morte súbita nos aconselhados a } \\
\text { ingerir peixe oleoso, especialmente entre os que receberam cápsulas de } \\
\text { óleo de peixe. }\end{array}$ \\
\hline $\mathrm{OPACH}^{176}$ & $\begin{array}{l}206 \text { pacientes em } \\
\text { hemodiálise crônica }\end{array}$ & $\begin{array}{l}\text { Ômega-3 ( } 1,7 \mathrm{~g} / \mathrm{dia}) \text { ou } \\
\text { controle (óleo de oliva) }\end{array}$ & 2 anos & $\begin{array}{c}\text { Ômega-3 não reduziu eventos CV totais e morte, porém reduziu o número } \\
\text { de IAM (obs.: } 25 \% \text { dos pacientes foram retirados do estudo por } \\
\text { diferentes motivos). }\end{array}$ \\
\hline JELIS ${ }^{177}$ & $\begin{array}{l}18645 \text { indivíduos } \\
\text { hipercolesterolêmicos } \\
\text { (colesterol total } \\
\geq 251 \mathrm{mg} / \mathrm{dL} \text { ) }\end{array}$ & $\begin{array}{l}\mathrm{EPA}(1,8 \mathrm{~g} / \mathrm{dia})+ \\
\text { estatina ou apenas } \\
\quad \text { estatina }\end{array}$ & 4,6 anos & $\begin{array}{l}\text { EPA reduziu significativamente o risco de eventos coronários } \\
\text { maiores em } 19 \% .\end{array}$ \\
\hline GISSI-HF ${ }^{178}$ & $\begin{array}{l}6975 \text { pacientes com IC } \\
\text { CF II-IV }\end{array}$ & $\begin{array}{l}\text { Ômega-3 (1 g/dia) ou } \\
\text { placebo }\end{array}$ & 3,9 anos & Ômega-3 reduziu significativamente a mortalidade total em 9\%. \\
\hline Alpha Omega ${ }^{179}$ & 4837 com IAM prévio & $\begin{array}{c}\text { Margarina } \\
\text { suplementada com } \\
\text { EPA+DHA (alvo: } \\
400 \text { mg/dia) ou com } \\
\text { ALA ou EPA+DHA+ALA } \\
\text { ou margarina placebo }\end{array}$ & 40 meses & $\begin{array}{c}\text { EPA+DHA ou ALA não reduziu a taxa de eventos cardiovasculares } \\
\text { maiores. EPA+DHA reduziu a mortalidade por doença coronária em } \\
\text { diabéticos. }\end{array}$ \\
\hline $\mathrm{OMEGA}^{180}$ & $\begin{array}{l}3851 \text { pacientes } 3 \text { a } 14 \\
\text { dias após IAM }\end{array}$ & $\begin{array}{l}\text { Ômega-3 altamente } \\
\text { purificado ( } 1 \mathrm{~g} / \text { dia }) \text { ou } \\
\text { placebo }\end{array}$ & 1 ano & $\begin{array}{l}\text { Taxas de morte súbita cardíaca e outros eventos clínicos foram baixas e } \\
\text { não se modificaram com ômega-3. }\end{array}$ \\
\hline SU.FOL.OM3 ${ }^{181}$ & $\begin{array}{l}2501 \text { pacientes com } \\
\text { história de IAM, } \\
\text { angina instável ou AVE } \\
\text { isquêmico }\end{array}$ & $\begin{array}{l}\text { Desenho fatorial: } \\
\text { vitaminas B ou placebo; } \\
\text { ômega-3 (EPA+DHA } \\
600 \mathrm{mg} / \mathrm{d} \text { ) ou placebo }\end{array}$ & 4,7 anos & Ômega-3 não reduziu eventos CV maiores. \\
\hline
\end{tabular}

ALA: ácido alfalinolênico; CF: classe funcional; CV: cardiovascular; DHA: ácido docosaexaenoico; EPA: ácido eicosapentaenoico; IC: insuficiência cardíaca; IAM: Infarto agudo do miocárdio

\subsubsection{Subgrupo de pacientes com insuficiência cardíaca sistólica \\ O grande ensaio randomizado GISSI-HF mostrou redução de mortalidade quando ácido graxo Ômega-3 (1 g/dia) foi suplementado a pacientes em classe funcional II-IV, em consistência com outros estudos epidemiológicos e observacionais que sugeriram uma relação inversa entre consumo de peixe ou Ômega-3 e eventos relacionados à insuficiência cardíaca ${ }^{192,193}$.}

\subsection{Recomendações}

Com base no exposto, podemos fazer as recomendações expostas na tabela 8.

Como a grande maioria dos estudos avaliou EPA e DHA de forma combinada, no momento não existe evidência suficiente para se fazer recomendações separadas para cada um desses ácidos graxos.

\subsection{Notas sobre suplementos de Ômega-3}

\subsubsection{Administração}

Existem no mercado várias formulações de óleo de peixe rico em ácido graxo Ômega-3. Em nosso meio, a quantidade de EPA e DHA por cápsula de óleo de peixe é variável, alcançando 90\% ou 1000 mg nas apresentações mais concentradas; o restante da cápsula é composto por outros ácidos graxos poli-insaturados, monoinsaturados e saturados, além de gelatina e glicerina com veículos. Preparação mais purificada, com 85\% de EPA-DHA, é comercializada no exterior, e formulação semi-sintética de EPA está sendo avaliada em estudos clínicos.

É altamente recomendado que a suplementação seja prescrita e acompanhada por um profissional médico e/ou nutricionista especialista na área. 


\section{Tabela 7 - Principais metanálises e revisões sistemáticas que avaliaram o efeito de peixe/Ômega-3 marinho sobre desfechos cardiovasculares}

\begin{tabular}{|c|c|c|c|}
\hline Estudo & População & $\begin{array}{l}\text { Intervenção ou componente da dieta } \\
\text { analisado }\end{array}$ & Resultado \\
\hline Bucher $2002^{182}$ & $\begin{array}{l}15.806 \text { pacientes com DAC; ensaios } \\
\text { randomizados e controlados }\end{array}$ & $\begin{array}{l}\text { Ômega-3 da dieta ou suplementado vs } \\
\text { dieta-controle ou placebo }\end{array}$ & $\begin{array}{l}\text { Intervenção reduziu mortalidade total, } \\
\text { mortalidade por IAM e MSC. }\end{array}$ \\
\hline Hooper $2004^{183}$ & $\begin{array}{l}\text { Prevenção primária e secundária; } \\
\text { ensaios randomizados e controlados, } \\
\text { e coortes prospectivas }\end{array}$ & Ômega-3 da dieta ou suplementado & $\begin{array}{c}\text { Consumo de Ômega-3 não se associou a } \\
\text { redução de mortalidade total ou eventos CV } \\
\text { combinados. }\end{array}$ \\
\hline He $2004^{184}$ & 222.364 indivíduos; estudos de coorte & Consumo de peixe & $\begin{array}{l}\text { Maior consumo de peixe associou-se a menor } \\
\text { mortalidade coronariana. }\end{array}$ \\
\hline Wang $2006^{185}$ & $\begin{array}{l}\text { Prevenção primária e secundária; } \\
\text { ensaios randomizados e controlados, } \\
\text { coortes prospectivas e estudos } \\
\text { caso-controle }\end{array}$ & $\begin{array}{c}\text { Consumo de peixe ou óleo de peixe rico } \\
\text { em EPA-DHA ou ALA }\end{array}$ & $\begin{array}{l}\text { Sugeriu redução da mortalidade total, mortalidade } \\
\text { cardíaca, MSC e possivelmente AVE por Ômega-3 } \\
\text { de origem marinha, mas não ALA. A evidência de } \\
\text { benefício do óleo de peixe foi maior na prevenção } \\
\text { secundária do que na primária. }\end{array}$ \\
\hline Mozaffarian $2006^{186}$ & $\begin{array}{l}\text { População geral; prioritariamente } \\
\text { ensaios randomizados e grandes } \\
\text { estudos prospectivos }\end{array}$ & Consumo de peixe & $\begin{array}{l}\text { Consumo moderado de peixe (1-2 porções por } \\
\text { semana), especialmente de espécies ricas em EPA- } \\
\text { DHA, reduziu significativamente o risco de morte } \\
\text { coronária em } 36 \% \text { e de mortalidade total em } 17 \% \text {; } \\
250 \text { mg/dia de EPA+DHA pareceram ser suficientes } \\
\text { para prevenção cardiovascular primária. }\end{array}$ \\
\hline León $2008^{187}$ & $\begin{array}{l}32.779 \text { indivíduos; ensaios } \\
\text { randomizados e controlados }\end{array}$ & Suplementação com óleo de peixe & $\begin{array}{l}\text { Intervenção associou-se a redução significativa de } \\
\text { mortes de causa cardíaca, mas não se observou } \\
\text { efeito sobre arritmias ou mortalidade total. }\end{array}$ \\
\hline Marik $2009^{188}$ & $\begin{array}{l}39.044 \text { pacientes com IAM recente, } \\
\text { CDI, IC, doença vascular periférica } \\
\text { ou hipercolesterolemia; ensaios } \\
\text { randomizados e controlados }\end{array}$ & $\begin{array}{l}\text { Suplementos de EPA-DHA }(1,8 \pm \\
1,2 \mathrm{~g} / \text { dia) vs placebo }\end{array}$ & $\begin{array}{l}\text { Intervenção reduziu significativamente } \\
\text { mortalidade CV (13\%), MSC (13\%), mortalidade } \\
\text { total ( } 8 \% \text { e eventos CV não fatais }(8 \%) .0 \\
\text { benefício sobre mortalidade se deveu, sobretudo } \\
\text { aos estudos com pacientes de alto risco. }\end{array}$ \\
\hline Mente $2009^{133}$ & $\begin{array}{l}\text { Prevenção primária e secundária; } \\
\text { coortes prospectivas e ensaios } \\
\text { randomizados e controlados }\end{array}$ & Consumo de peixe e de ômega-3 marinho & $\begin{array}{c}\text { Maior consumo de peixe e ômega-3 marinho } \\
\text { associou-se a menor risco de doença arterial } \\
\text { coronariana. }\end{array}$ \\
\hline
\end{tabular}

ALA: ácido alfalinolênico; AVE: acidente vascular encefálico; CDI: cardiodesfibrilador implantável; CV: cardiovascular; DAC: doença arterial coronária; DHA: ácido docosaexaenoico; EPA: ácido eicosapentaenoico; IC: insuficiência cardiaca; IAM: Infarto agudo do miocárdio; MSC: morte súbita cardíaca

Tabela 8 - Recomendações para consumo de produtos ricos em ácido graxo Ômega-3

\begin{tabular}{|c|c|c|}
\hline Recomendação & $\begin{array}{l}\text { Grau de } \\
\text { recomendação }\end{array}$ & $\begin{array}{l}\text { Nível de } \\
\text { evidência }\end{array}$ \\
\hline $\begin{array}{l}\text { Suplementação com ômega-3 marinho ( } 2-4 \mathrm{~g} / \mathrm{dia} \text { ) deve ser recomendada para hipertrigliceridemia grave (> } 500 \mathrm{mg} / \mathrm{dL} \text { ), } \\
\text { com risco de pancreatite, refratária a medidas não farmacológicas e tratamento medicamentoso. }\end{array}$ & I & $A$ \\
\hline $\begin{array}{l}\text { Pelo menos duas refeições a base de peixe por semana, como parte de uma dieta saudável, devem ser recomendadas para } \\
\text { diminuir o risco cardiovascular. Tal recomendação é particularmente dirigida para indivíduos de alto risco, como os que já } \\
\text { apresentaram infarto do miocárdio. }\end{array}$ & I & $B$ \\
\hline $\begin{array}{l}\text { Suplementação com Ômega- } 3 \text { marinho }(\sim 1 \mathrm{~g} / \text { dia) pode ser recomendada para diminuir o risco cardiovascular em indivíduos } \\
\text { de risco baixo a moderado que não consomem duas refeições a base de peixe por semana, embora o real benefício dessa } \\
\text { recomendação seja discutível. }\end{array}$ & Ilb & $B$ \\
\hline $\begin{array}{l}\text { Suplementação com Ômega-3 marinho ( } 1 \mathrm{~g} / \mathrm{dia}) \text { pode ser recomendada para diminuir o risco cardiovascular em indivíduos } \\
\text { de alto risco, como os sobreviventes de infarto do miocárdio ou insuficiência cardíaca sistólica, embora o real benefício dessa } \\
\text { recomendação seja discutível. O benefício parece ser menor ou nulo quando o paciente recebe tratamento otimizado, de acordo } \\
\text { com as recomendações vigentes, e tem seus fatores de risco bem controlados. }\end{array}$ & Ilb & $A$ \\
\hline
\end{tabular}




\subsubsection{Efeitos colaterais}

Os efeitos colaterais da suplementação de ácido graxo Ômega-3 mais comumente relatados são os relacionados com o trato gastrointestinal, que podem ocorrer em $\sim 4 \%$ em dosagens $<3 \mathrm{~g} /$ dia e em até $\sim 20 \%$ em dosagens de $4 \mathrm{~g} / \mathrm{dia}^{185}$. Além disso, a sensação de "cheirar peixe" é causa frequente de descontinuação do suplemento. Podem contribuir para melhor aderência: congelar o óleo de peixe, consumir durante as refeições, modificar o horário da ingestão ou mudar para outra formulação.

\subsubsection{Segurança}

Considerando a descrição de efeitos antiplaquetários dos ácidos graxos Ômega-3 marinhos, uma preocupação justa seria a possibilidade de facilitar sangramentos. No entanto, estudos clínicos não têm revelado aumento do risco de hemorragias induzido por ácido graxo Ômega-3, mesmo quando prescritos em altas doses $(\sim 3-4 \mathrm{~g} / \mathrm{d})$, por tempo prolongado ( $>2$ anos) e mesmo quando associados a aspirina e clopidogrel ou varfarina ${ }^{194,195}$.

A preocupação com ingestão de contaminantes, como mercúrio, também não se justifica ${ }^{147}$. De forma semelhante ao que ocorre para a maioria das espécies de peixe, o óleo de peixe comercializado contém pouco ou nenhum mercúrio.

\section{5. Ácidos graxos poli-insaturados Ômega-3 de origem vegetal}

\subsubsection{Efeitos sobre o metabolismo lipídico}

O ácido graxo alfalinolênico (ALA) tem demonstrado efeitos inconsistentes sobre os níveis lipídicos ${ }^{134}$. Em uma revisão sistemática e metanálise de 14 ensaios randomizados e controlados com suplementação com ALA, não se observou influência significativa sobre colesterol total, LDL-colesterol ou triglicérides, encontrando-se um efeito mínimo sobre o HDL-colesterol (redução de 0,4 mg/dL) ${ }^{196}$.

Especificamente, os efeitos da linhaça em animais de experimentação variam de efeito nulo a discreta redução lipídica ${ }^{197}$, e uma revisão sugeriu um efeito redutor de triglicérides pelo consumo de grandes quantidades de óleo de linhaça em humanos ${ }^{135}$.

\subsubsection{Efeitos sobre o metabolismo glicídico}

Os efeitos do ALA sobre o perfil glicêmico também não têm sido consistentes ${ }^{134}$, havendo, no entanto, sugestões de que o seu consumo possa beneficiar o metabolismo glicídico. Dados prospectivos do Cardiovascular Health Study mostraram que concentrações plasmáticas mais elevadas de ALA associaramse a menor chance de novos casos de Diabetes Mellitus $(\mathrm{DM})^{142}$. De forma concordante, em uma grande análise prospectiva de mais de 43 mil chineses, o consumo de ALA associou-se inversamente ao risco de aparecimento de $\mathrm{DM}^{141}$. Na revisão sistemática e metanálise de ensaios randomizados e controlados citada antes, a suplementação com ALA reduziu a glicemia em 3,6 mg/dL ${ }^{196}$. Com relação à linhaça, um estudo randomizado revelou melhora da sensibilidade a insulina ${ }^{198}$.

\subsubsection{Efeitos sobre a inflamação}

Tem sido sugerido que ingestão de $>14$ g de ALA ao dia reduz marcadores inflamatórios ${ }^{197}$. De fato, várias investigações atestam uma relação inversa entre consumo de ALA e parâmetros inflamatórios, incluindo PCR sérica ${ }^{148,199,200}$. A suplementação com ALA diminui os níveis de marcadores inflamatórios em indivíduos dislipidêmicos ${ }^{201}$, o que ocorre especialmente quando a dieta de base é rica em gordura saturada e pobre em monoinsaturada ${ }^{202}$.

\subsubsection{Efeitos sobre eventos cardiovasculares}

Embora ainda esteja em discussão a real influência dos ácidos graxos Ômega-3 de origem vegetal sobre a doença cardiovascular, a maior parte dos estudos observacionais prospectivos sugere que o consumo de ALA pode proteger contra eventos cardiovasculares ${ }^{203}$.

Na análise prospectiva de mais de 45 mil homens do Health Professionals Follow-up Study, por exemplo, o consumo de ácido graxo Ômega-3, tanto de origem marinha como vegetal, associou-se à redução do risco cardiovascular, com pouca influência da ingestão de Ômega- $6^{204}$.

Já no Nurses' Health Study, que acompanhou mais de 76 mil mulheres, o consumo de ALA associou-se inversamente ao risco de morte súbita cardíaca, mas não a outros tipos de desfechos coronarianos fatais ou infarto do miocárdio não fatal ${ }^{205}$.

Metanálises e revisões sistemáticas têm mostrado resultados contraditórios ${ }^{133,185,206}$ e, no estudo randomizado e controlado Alpha Omega, margarina suplementada com ALA por 40 meses não reduziu a taxa de eventos cardiovasculares maiores em pacientes que já haviam sofrido infarto do miocárdio ${ }^{179}$.

\subsection{Recomendações}

A tabela 9 resume a recomendação referente ao consumo de produtos ricos em ácido graxo Ômega-3 de origem vegetal. Considerando o exposto, pode-se dizer que há indícios de possíveis benefícios cardiovasculares dos ácidos graxos Ômega-3 de origem vegetal, embora conclusões mais definitivas, sobretudo sobre os efeitos sobre desfechos duros (morte, infarto do miocárdio), devam aguardar estudos randomizados e controlados futuros.

Tabela 9 - Recomendação para consumo de produtos ricos em ácido graxo Ômega-3 de origem vegetal

\begin{tabular}{lcc}
\hline Recomendação & $\begin{array}{c}\text { Grau de } \\
\text { recomendação }\end{array}$ & $\begin{array}{c}\text { Nível de } \\
\text { evidência }\end{array}$ \\
\hline $\begin{array}{l}\text { Estimular o consumo de ácidos graxos } \\
\text { poli-insaturados Ômega-3 de origem } \\
\text { vegetal, como parte de uma dieta }\end{array}$ & \\
saudável, pode ser recomendado para & ।lb & \\
reduzir o risco cardiovascular, embora & & \\
o real benefício dessa recomendação & & \\
seja discutível e as evidências não sejam & & \\
conclusivas. & & \\
\end{tabular}




\section{7. Ácido graxo poli-insaturado N-6 (ALA)}

\subsubsection{Efeitos sobre o metabolismo lipídico}

Vários estudos apontam para um efeito redutor de colesterol pelo Ácido Linoleico (AL) em humanos ${ }^{53}$. Altos níveis plasmáticos de PUFA são associados com uma redução da razão entre o colesterol total e o HDL-c, e estudos epidemiológicos mostram que a substituição de $10 \%$ de calorias provenientes de SFA por PUFA Ômega-6 associa-se a uma redução de $18 \mathrm{mg} / \mathrm{dL}$ no LDL-c, maior que a observada com reposição semelhante por carboidratos ${ }^{53}$.

\subsubsection{Efeitos sobre o metabolismo glicídico}

Estudos observacionais, utilizando marcadores biológicos da ingestão de gorduras ou de questionários dietéticos, sugerem uma associação inversa entre a ingestão de Ômega-6 e risco de Diabetes Mellitus (DM), embora os dados nem sempre sejam consistentes ${ }^{207,208}$.

No Nurses' Health Study, envolvendo 84.204 mulheres com idade entre 34 e 59 anos, sem DM, doença cardiovascular ou câncer, seguidas prospectivamente por seis anos, a ingestão de PUFA, avaliada por questionários devidamente validados, associou-se a um menor risco de DM tipo $2^{208}$.

Em homens, outro grande estudo prospectivo, o Health Professionals Follow-Up Study, também mostrou que a ingestão de $\mathrm{AL}$ estava associada a um menor risco de DM tipo 2 naqueles com idade $<65$ anos e IMC $<25 \mathrm{~kg} / \mathrm{m}^{2} 209$.

Em contrapartida, no estudo Singapore Chinese Health Study, no qual mais de 43 mil chineses foram avaliados prospectivamente, o consumo de Ômega-6 não se associou ao aparecimento de novos casos de $\mathrm{DM}^{141}$.

Os dados provenientes de pequenos estudos de intervenção também são controversos no que diz respeito ao efeito dos PUFA Ômega-6/AL sobre a sensibilidade a insulina ${ }^{210,211 . ~}$

Embora não conclusivas, existem, portanto, evidências que permitem sugerir a substituição de SFA e trans por PUFA com o objetivo de diminuir o risco de DM tipo 2. Além disso, há evidências de um maior efeito protetor dos ácidos graxos Ômega-6 em relação aos Ômega-3 sobre o risco de DM ${ }^{111}$.

Mais estudos controlados de longo prazo são necessários para identificar a melhor composição de AG da dieta para reduzir o risco de DM tipo 2. Além disso, há poucos dados disponíveis sobre os efeitos da qualidade da gordura da dieta em indivíduos com DM, e a proporção ideal de SFA, PUFA e MUFA nesse subgrupo permanece incerta.

\subsubsection{Efeitos sobre a inflamação}

O Ácido Araquidônico (AA) é o substrato para a produção de uma ampla variedade de eicosanoides (metabólitos de carbono 20-AA), e alguns têm características pró-inflamatórias, vasoconstritoras e/ou pró-agregantes, como a prostaglandina E2, o tromboxano A2 e o leucotrieno B4.

O AA, no entanto, também serve de substrato para outros eicosanoides com características anti-inflamatórias/antiagregantes, como a prostaciclina, a lipoxina $\mathrm{A} 4{ }^{212}$ eácidos epoxieicosatrienoicos, que possuem importante efeito vasodilatador ${ }^{213}$.

Além disso, alguns estudos mostram que o consumo de AL e sua proporção no soro relacionam-se inversamente com as concentrações de proteína C-reativa ${ }^{200,214,215}$.

\subsubsection{Efeitos sobre eventos cardiovasculares}

Mesmo com algumas limitações quanto a tamanho amostral e uniformidade de desfechos, os resultados combinados dos estudos clínicos randomizados e observacionais fornecem evidências de que a substituição dos SFA e carboidratos refinados (por exemplo, açúcar, pão branco, arroz branco, batata) por PUFA Ômega-6, ao redor de 5\% a 10\% de energia consumida, reduz o risco de doença cardiovascular, sem evidências clínicas de eventos adversos ${ }^{216-219}$.

Nos países ocidentais ou ocidentalizados em relação à dieta, a substituição de 1\% do consumo de energia a partir de SFA por PUFA tem sido associada com uma redução de 2\%-3\% na incidência de doença coronariana ${ }^{61,220}$. Esse benefício ainda pode estar subestimado em razão da grande quantidade de SFA que co-ocorre em algumas fontes de alimentos com PUFA.

Para Mente e cols. ${ }^{133}$, em estudo envolvendo indivíduos em prevenção primária e secundária de estudos de coorte prospectivos e ensaios clínicos randomizados, o consumo de PUFA não se associou a menor risco de doença arterial coronariana, ao contrário do que foi observado para a ingestão de peixes ou PUFA Ômega-3 marinho. De fato, vários estudos mostram que a redução nos desfechos cardiovasculares é menor com a substituição dos SFA por PUFA Ômega-6 do que quando comparada com uma substituição por uma mistura de PUFA Ômega-6 com Ômega- $3^{221}$.

\subsubsection{A relação Ômega-6/Ômega-3}

O papel da relação Ômega-6/Ômega-3 na dieta sobre a patogênese de doenças cardiovasculares, inflamatórias e autoimunes tem sido objeto de bastante controvérsia nos últimos anos.

A espécie humana experimentou mudanças drásticas na sua alimentação em relação à ingestão de ácidos graxos nos últimos milênios. Com a revolução agrícola, houve um aumento do consumo de cereais, óleos e grãos ricos em ácidos graxos Ômega-6 e uma diminuição paralela da ingestão de ácidos graxos Ốmega-3. A relação Ômega-6/Ômega-3, originalmente em torno de $1: 1$ a 2:1, hoje se situa de 15:1 a 40:1 na dieta ocidental 222,223 .

Em teoria, o aumento da ingestão de Ômega- 6 poderia elevar a geração de mediadores inflamatórios implicados com diversas processos patológicos, incluindo aterosclerose e seus fatores de risco tradicionais, como hipertensão arterial, diabetes e obesidade. No entanto, a real relevância clínica desse possível efeito é motivo de intensa discussão.

A maior parte dos estudos conclui que, para a promoção de saúde geral, a relação Ômega-6/Ômega-3 deveria ser mais baixa do que a atualmente encontrada na população geral ocidental224. Alguns especialistas advogam diminuir essa relação por meio tanto do aumento do consumo de Ômega-3 como também pela redução de Ômega-6. De forma condizente, em um estudo clínico prospectivo de prevenção secundária em indíviduos pós-infarto do miocárdio, uma dieta experimental mediterrânea caracterizada, entre outros fatores, por ser mais rica em ácido linolênico e oleico e mais pobre em linoleico, associou-se a uma redução de até $70 \%$ na mortalidade total ${ }^{219}$. Tal dieta incluía substituição de óleo de milho por azeite de oliva e diminuiu a relação Ômega-6/ Ômega-3 até 4/1225. 
Enquanto, porém, existem evidências substanciais de que o aumento da ingestão de Ômega-3, particularmente dos ácidos docosaexaenoico (DHA) e eicosapentaenoico (EPA), confere proteção contra doenças cardiovasculares, não existem evidências convincentes de que a redução do consumo de Ômega-6, por si só, faça o mesmo. Pelo contrário, pode até aumentar o risco cardiovascular ${ }^{22}$.

Além disso, a validade de se utilizar apenas a relação Ômega-6/Ômega-3 na prática clínica e sua relação com o risco cardiovascular tem sido questionada por diversos especialistas ${ }^{226,227}$. Ambos os ácidos Ômega-6 e Ômega-3 têm sido associados a efeitos benéficos para a saúde cardiovascular. Entretanto, a importância da relação Ômega-6/Ômega-3 fundamenta-se na competição existente entre os ácidos linoleico (Ômega-6) e alfalinolênico (Ômega-3) pela ação da enzima delta- 6 dessaturase, que converte ambos em diferentes subespécies. Por um lado, um consumo elevado de ácido linoleico pode diminuir o metabolismo do ácido alfalinolênico a EPA e DHA ${ }^{228}$, limitando os benefícios do ácido Ômega-3. Por outro, a afinidade maior da enzima delta-6-dessaturase pelos ácidos graxos Ômega-3 pode fazer que os metabólitos essenciais derivados da bioconversão do ácido linoleico não sejam produzidos de forma satisfatória, o que justificaria uma recomendação para um pequeno aumento de seu consumo quando comparado ao ácido Ômega- $3^{226}$.

Diante dessas questões e até que surjam novas informações científicas que permitam modificações de conduta, as recomendações dietéticas atualmente devem ser feitas com base no consumo total de cada PUFA e não somente com base na relação Ômega-6/Ômega-3.

\subsection{Recomendações}

A tabela 10 resume as principais recomendações referentes ao consumo de ácidos graxos Ômega- 6 da dieta.

Tabela 10 - Recomendações para consumo de produtos ricos em ácido graxo Ômega-6

\begin{tabular}{lcc}
\hline Recomendação & $\begin{array}{c}\text { Grau de } \\
\text { recomendação }\end{array}$ & $\begin{array}{c}\text { Nível de } \\
\text { evidência }\end{array}$ \\
\hline $\begin{array}{l}\text { Substituir ácidos graxos saturados da } \\
\text { dieta por poli-insaturados, incluindo } \\
\text { Ômega-6, deve ser recomendado para } \\
\text { otimizar a redução dos níveis plasmáticos }\end{array}$ & I & A \\
de LDL-colesterol. & & \\
\hline $\begin{array}{l}\text { Substituir ácidos graxos saturados da } \\
\text { dieta por poli-insaturados Ômega-6 }\end{array}$ & & B \\
pode ser recomendado para melhorar & & \\
a sensibilidade a insulina e reduzir 0 \\
risco de diabetes mellitus, embora as \\
evidências não sejam absolutamente \\
conclusivas.
\end{tabular}

\section{Efeitos e recomendações do consumo dos ácidos graxos trans sobre mecanismos fisiopatológicos do processo aterosclerótico: biomarcadores e desfechos clínicos}

\section{1. Ácidos graxos Trans}

\subsubsection{Colesterol total e frações e triglicérides}

Os ácidos graxos trans relacionam-se fortemente com o risco cardiovascular, especialmente em razão de aumentarem a concentração plasmática de colesterol e de LDL-C ${ }^{53,229-232}$, bem como possuem efeito adverso adicional, em razão de reduzirem a concentração plasmática de HDL-c, lipoproteína inversamente relacionada a eventos cardiovasculares ${ }^{233}$. Uma importante Metanálise discutiu os resultados de 60 estudos bem controlados e reafirmou o impacto dos ácidos graxos trans tanto sobre a elevação da colesterolemia quanto sobre a redução da concentração plasmática de HDL- $\mathrm{C}^{53}$.

Em razão da sua importância no contexto da doença cardiovascular, diversos mecanismos têm sido investigados com o propósito de elucidar as suas possíveis ações na elevação da colesterolemia e no desenvolvimento da aterogênese. Já foi demonstrado que, pelo fato de possuírem cadeia retilínea de carbono, promovem o aumento das concentrações de colesterol total e LDL-c por mecanismos semelhantes aos dos ácidos graxos saturados. Nesse sentido, verifica-se que os ácidos graxos trans empacotam-se nas LDL-c, o que disponibiliza maior espaço nessa partícula para o transporte de colesterol e, além disso, reduzem a expressão gênica dos receptores hepáticos (receptor B-E) responsáveis pela captação das partículas de $\mathrm{LDL}^{234-236}$.

A redução da concentração plasmática de HDL-c pode ser explicada pelo fato de os ácidos graxos trans induzirem aumento da atividade da CETP, proteína envolvida em importante etapa do transporte reverso de colesterol, a qual é responsável pela transferência de colesterol éster das HDL para VLDL e $\mathrm{LDL}^{237}$. Adicionalmente, aumentam o catabolismo das Apo A1, principal proteína presente nas HDL, a qual é responsável por parte da retirada de colesterol presente nos macrófagos das placas de ateroma ${ }^{235,236}$, e diminuição do catabolismo da apolipoproteína B-100 235,237. Cabe ainda ressaltar que os ácidos graxos trans reduzem as HDL2, subfração mais sensível a modificações alimentares. Além disso, demonstrou-se em animais que essa gordura induz a produção de partículas de HDL mais enriquecidas em triglicérides ${ }^{238}$, as quais são melhor substrato para a lipase hepática, enzima envolvida no catabolismo das $\mathrm{HDL}^{239}$. Dessa forma, os ácidos graxos trans induzem perfil lipídico próaterogênico, fato que culmina em maior risco cardiovascular.

Com relação à influência desses ácidos graxos da dieta sobre a capacidade da HDL em retirar colesterol de macrófagos, demonstrou-se que a gordura trans não alterou a eficiência dessa partícula em comparação aos ácidos graxos poli-insaturados ou saturados ${ }^{240}$. Portanto, sua ação deletéria não pode ser explicada pela participação na primeira etapa do transporte reverso de colesterol. É importante salientar que, neste estudo, realizado com indivíduos normais e jovens, utilizou-se quantidade regular de gordura (30\% das calorias). Dessa forma, outras possíveis ações aterogênicas desses ácidos graxos, relativas ao efluxo de colesterol das artérias, necessitam ser mais bem exploradas. 
Além da sua ação sobre a colesterolemia, os ácidos graxos trans também influenciam a concentração plasmática de triglicérides ${ }^{238}$. Em camundongos com deficiência no receptor de LDL-C, o consumo de dieta normolipídica enriquecida com ácidos graxos trans aumentou a expressão hepática de genes envolvidos na síntese de TG e na produção de VLDL, tais como a ácido graxo sintase (FAS), a proteína de ligação ao elemento responsivo a esteroides-1c (SREBP-1C), a proteína microssomal de transferência de triacilglicerois (MTP) e a apo B100 ${ }^{241}$. Utilizando o mesmo modelo animal, trabalho recente mostrou perfil de lipoproteínas mais aterogênico, com aumento nas concentrações de VLDL, LDL, CT e TG com relação aos animais que consumiram dieta hiperlipídica contendo ácidos graxos poli-insaturados ou saturados ${ }^{238}$. Outros efeitos deletérios dos ácidos graxos trans no contexto cardiovascular estão relacionados ao aumento nas concentrações plasmáticas de LDL pequenas e densas, partículas reconhecidamente mais aterogênicas ${ }^{242}$.

\subsubsection{Glicemia e resistência a insulina}

Diversos estudos demonstraram piora na sensibilidade à ação da insulina induzida pelos ácidos graxos trans em animais ${ }^{243} \mathrm{e}$ em humanos, particularmente entre indivíduos que apresentam predisposição a resistência a insulina ${ }^{244}$, elevando, assim, o risco para o desenvolvimento de diabetes tipo $2^{232}$. Em comparação aos ácidos graxos saturados e poli-insaturados, os trans prejudicam a tolerância a glicose, caracterizada pelo HOMA - IR (Homeostasis Model Assessment) devido a maior lipogênese hepática ${ }^{245}$.

Além disso, esses ácidos graxos induzem redução da síntese das proteínas estimuladoras de acilação (ASP), as quais estão relacionadas com a captação de triglicérides pelo adipócito e sua redistribuição. Essas proteínas interagem com membranas celulares, estimulando a diacilglicerol, a qual, via proteína C-quinase, regula a síntese de triglicérides. Além disso, as ASP agem sobre a captação da glicose independentemente da ação da insulina. Dessa forma, a diminuição da concentração plasmática das ASP no plasma, por meio do consumo de ácidos graxos trans, poderia contribuir indiretamente para o fenômeno de resistência periférica à ação da insulina ${ }^{244}$.

A resistência à ação da insulina é provavelmente a principal alteração que precede e predispõe à síndrome metabólica. Diversos autores têm sugerido que a esteatose hepática não alcoólica (NAFLD) seja uma das manifestações clínicas da síndrome metabólica no fígado. Estudo de intervenção conduzido em camundongos LDL-/- submetidos a dieta com 40\% de gordura, enriquecida com diferentes ácidos graxos, demonstrou que todos os animais desenvolveram esteatose hepática. No entanto, o grupo de animais que consumiu ácidos graxos trans apresentou maior infiltrado de gordura e desenvolveu esteatohepatite não alcoólica (NASH) devido a maior lipogênese ${ }^{238}$. Em outro experimento, testaram-se padrões relacionados ao estilo de vida ocidental, os quais incluíam o consumo de dieta rica em gordura, ácidos graxos trans e frutose, além de intervenções que induziram comportamento sedentário em camundongo. Neste estudo, observou-se que os ácidos graxos trans exerceram a maior influência na promoção da esteatose hepática ${ }^{245}$.

Além disso, já se demonstrou que os ácidos graxos trans prejudicam a função mitocondrial e aumentam o estresse do retículo endoplasmático, condições relacionadas ao fenômeno de resistência periférica à ação da insulina ${ }^{241}$.
O consumo de trans vem sendo acompanhado pelo aumento na incidência da obesidade mundial, epidemia que vem crescendo, em todas as faixas etárias, contribuindo para o desenvolvimento da aterogênese ${ }^{246}$.

\subsubsection{Biomarcadores inflamatórios}

A forte associação entre consumo de trans e doença cardiovascular não pode ser explicada apenas por sua ação sobre os lípides plasmáticos, uma vez que outras vias metabólicas estão envolvidas na indução da aterogênese. Em razão de os processos inflamatórios estarem intimamente relacionados aos eventos cardiovasculares, diversos estudos clínicos de intervenção foram conduzidos nos últimos anos no sentido de elucidar a implicação desses ácidos graxos sobre a inflamação. Estudos de intervenção encontraram efeitos variados na ação dos ácidos graxos trans e marcadores inflamatórios. Estudos crossover demonstraram aumento da concentração plasmática de TNF-alfa, IL-6, e PCR após o consumo de ácidos graxos trans, tanto em indivíduos saudáveis quanto em portadores de hipercolesterolemia ${ }^{90,247}$. Outro estudo não mostrou elevação da proteína C-reativa ${ }^{248}$. As investigações nas quais houve aumento da concentração plasmática de IL-6, proteína C-reativa e E-selectina tiveram a duração de 4-5 semanas e utilizaram 7\% do valor calórico total na forma de ácidos graxos trans ${ }^{90,247}$.

Mozafarian e cols. ${ }^{233}$ demonstraram em importante revisão a elevação da concentração plasmática de TNF-alfa, PCR e IL-6 com ácidos graxos trans, provocando efeitos pró-inflamatórios, alterações intimamente relacionadas à disfunção endotelial. Neste estudo, os efeitos foram mais proeminentes quando os ácidos graxos trans foram comparados aos poli-insaturados e efeitos adversos, tais como aumento da relação CT/HDL-c e disfunção endotelial foram observados em comparação a SFA.

Outra investigação realizada com indivíduos saudáveis demonstrou que o consumo de ácidos graxos trans (8\% do valor calórico total da dieta) provocou aumento significativo da concentração plasmática de PCR e de E-selectina em comparação ao consumo de dieta controle. Todavia, neste estudo, o consumo de TRANS não induziu aumento das concentrações plasmáticas de fibrinogênio e IL- $6^{247}$.

Outro estudo realizado com indivíduos adultos saudáveis demonstrou que o consumo de dieta contendo $7 \%$ do VCT na forma de ácidos graxos trans, durante um período de três semanas, teve poucos efeitos sobre a concentração plasmática de IL-6, proteína quimiotática para monócitos (MCP)-1 e receptor 2 do TNF) ${ }^{249}$. O consumo desse ácido graxo acarretou apenas em pequena redução da concentração plasmática do receptor 1 do TNF (4\%) e ligeiro aumento da concentração da E-selectina (6\%) em relação à dieta controle. Deve-se ressaltar, no entanto, que grande parte dos indivíduos estudados era de jovens ${ }^{249}$.

A partir do exposto, conclui-se, até o presente momento, que os resultados sobre a ação dos ácidos graxos trans sobre processos inflamatórios são ainda controversos. Provavelmente isso ocorra em razão da grande variabilidade nos critérios de inclusão dos indivíduos, bem como idade, presença ou não de dislipidemia além da duração do estudo 
e percentual de ácidos graxos trans das dietas. Assim, mais estudos são necessários para elucidar o papel desses ácidos graxos na indução da resposta inflamatória em indivíduos com risco cardiovascular.

\subsubsection{Aterosclerose e função endotelial}

Bassett e cols. ${ }^{250}$ verificaram que camundongos LDLr-KO que consumiram ácidos graxos trans desenvolveram mais lesões ateroscleróticas quando comparados aos grupos que não consumiram essa gordura. Lesão ainda maior foi observada naqueles que consumiram dieta rica em colesterol adicionada de trans, salientando a sua ação potencializadora sobre o efeito colesterol alimentar.

Ácidos graxos trans também elevam o risco de doença cardiovascular por provocarem ação direta no endotélio, induzindo apoptose, por meio de ativação da via das caspases $^{251}$. Recente revisão avaliou o resultado de estudos clínicos controlados sobre o risco e desfecho cardiovascular e mostraram piora na função endotelial induzida pelos ácidos graxos trans quando comparados aos ácidos graxos saturados ${ }^{233}$.

Estudos anteriores demonstraram que indivíduos infartados apresentavam maior concentração de ácidos graxos trans no tecido adiposo quando comparados a controles saudáveis ${ }^{252}$. O alto teor de ácidos graxos trans encontrados nos tecidos foi reflexo de maior consumo de produtos industrializados. Verificou-se também maior conteúdo de trans em eritrócitos de mulheres, fato que elevou em 2,7 vezes o risco para doença cardiovascular ${ }^{253}$ e redução na vasodilatação mediada pelo fluxo ${ }^{254}$.

\subsubsection{Estudos de desfecho cardiovascular}

Importantes estudos epidemiológicos, como Nurses's Health Study, Health Professionals Followup Study e Alpha-Tocopherol Beta-Carotene Study, evidenciaram maior risco para doença coronariana com o consumo de gordura trans ${ }^{132,255}$. No entanto, no estudo European Antioxidant Myocardial Infarctionand Cancer (EURAMIC), a concentração de ácidos graxos trans no tecido adiposo não foi significativamente associada ao risco de infarto do miocárdio ${ }^{256}$.

Recente revisão mostrou que cinco estudos caso-controle e quatro estudos prospectivos detectaram associação positiva entre o consumo de trans e eventos cardiovasculares ${ }^{233}$. A análise desses estudos evidenciou que a substituição isocalórica de $2 \%$ de ácidos graxos trans na dieta aumentou em $24 \%-34 \%$ o risco para infarto agudo do miocárdio ${ }^{233}$. Estudo prospectivo conduzido em mulheres mostrou que a redução de ácidos graxos trans é mais eficiente na prevenção da doença arterial coronariana do que a redução de gordura total da dieta ${ }^{257}$. Essa investigação mostrou ainda que a substituição de $2 \%$ das calorias provenientes de ácidos graxos trans por insaturados reduziria o risco relativo de doença cardiovascular em 53\%.

Demonstrou-se associação positiva entre o consumo de trans e infarto agudo do miocárdio, doença arterial coronariana e morte súbita em homens ${ }^{258}$. Contudo, esse risco parece ser maior quando se analisa mortalidade por doença coronariana ${ }^{132}$.

\begin{tabular}{lcc}
\hline Recomendação & $\begin{array}{c}\text { Grau de } \\
\text { recomendação }\end{array}$ & $\begin{array}{c}\text { Nível de } \\
\text { evidência }\end{array}$ \\
\hline $\begin{array}{l}\text { O consumo de ácidos graxos trans está } \\
\text { relacionado com alteração no perfil lípico } \\
\text { (aumento de colesterol total e LDL e }\end{array}$ & । & \\
diminuição de HDL). & & B \\
\hline $\begin{array}{l}\text { O consumo de ácidos graxos trans } \\
\text { está relacionado com diminuição de } \\
\text { triglicérides e aumento de partículas de } \\
\text { LDL pequenas e densas. }\end{array}$ & & \\
\hline
\end{tabular}

O consumo de ácidos graxos trans

está relacionado com aumento da sensibilidade insulínica, especialmente em indivíduos com predisposição a resistência insulínica, elevando risco para desenvolvimento e/ou progressão de diabetes mellitus tipo 2 .

\section{O consumo de ácidos graxos trans está} relacionado a aumento da inflamação.

O consumo de ácidos graxos trans está relacionado com aumento de risco para doença cardiovascular.

O consumo de ácidos graxos trans proveniente de produtos industrializados deve ser mínimo possível, não IIb B ultrapassando $1 \%$ do VCT

\subsubsection{Relação indústria / Anvisa}

Em razão dessas evidências quanto aos efeitos deletérios dos ácidos graxos trans, a Food and Drug Administration (FDA) designou, em 1999, que todos os produtos embalados deveriam indicar na rotulagem nutricional a quantidade dessa gordura presente na porção do produto a ser adquirido, o que no Brasil foi regulamentado na resolução RDC no 360 de 23 de dezembro de 2003. Nessa resolução, a Agência Nacional de Vigilância Sanitária (Anvisa) preconiza que apenas os produtos que contenham ácidos graxos trans em quantidade menor ou igual a 0,2 g por porção sejam designados como zero trans ${ }^{259}$.

Perante essas recomendações, as indústrias foram obrigadas a adequar seus produtos de forma a utilizar gorduras que tivessem quantidades reduzidas de ácidos graxos trans e que, ao mesmo tempo, proporcionassem as mesmas características organolépticas exigidas pelo consumidor Brasil. Resolução RDC no 360 da Agência Nacional de Vigilância Sanitária, 23 dezembro 2003. Disponível em: <http://e-legis.anvisa.gov.br / leisref / public / showAct.php?id=9059>. Acesso em: mar de 2010259.

É importante esclarecer que a indústria se baseia em porções estipuladas pela própria Anvisa; no entanto, o fato de a porção apresentar-se como isenta de trans não necessariamente assegura que o produto tenha sido produzido sem essa gordura.

Algumas empresas alimentícias têm evoluído no sentido de substituir ácidos graxos trans por outros tipos de gordura. No entanto, há uma grande preocupação por parte da comunidade científica em relação à escolha por parte da indústria do substituto para ácidos graxos trans, que têm sido os ácidos graxos saturados ${ }^{260}$. 


\section{Efeitos e recomendações do consumo dos ácidos graxos Interesterificados sobre mecanismos fisiopatológicos do processo aterosclerótico: biomarcadores e desfechos clínicos}

\section{1. Ácidos graxos Interesterificados}

\subsubsection{Estudos com animais}

Em ratos Wistar, a mistura de óleo de cártamo rico em oleico, óleo de cártamo rico em linoleico, óleo de linhaça e metil éster de ácido erúcico, na proporção 8,5:74:17,5:0,5 (p/p\%), submetida a interesterificação química, favoreceu menor concentração de colesterol total e livre no plasma quando relacionado ao grupo de animais que recebeu a dieta com a mistura sem passar pelo processo de interesterificação. Além disso, os animais que consumiram tanto a mistura interesterificada quanto a não interesterificada tiveram menor tempo de coagulação com relação ao grupo que recebeu uma dieta padrão ${ }^{261}$.

O efeito do óleo de coco e farelo de arroz ou óleo de coco e de gergelim misturados ou submetidos a interesterificação enzimática, com proporção de ácidos graxos saturado: monoinsaturado: poli-insaturado 1:1:1 e razão poli-insaturado/ saturado 0,8 a 1 por 60 dias, também foi avaliado em ratos Wistar $^{262}$. Os animais que consumiram óleos interesterificados apresentaram concentrações reduzidas de CT, LDL-c e TG quando comparados com ratos alimentados com óleos misturados, embora não tenha sido observada alteração no tamanho e na composição de fosfolípides hepáticos. Posteriormente, o mesmo grupo de pesquisadores verificou que essa ação estaria associada ao aumento na expressão do receptor hepático de LDL concomitante ao aumento na expressão dos genes que codificam para colesterol-7ahidroxilase (CYP7A1) e SREBP-2 ${ }^{263}$. Esses resultados sugerem que a modificação da posição do ácido graxo na molécula do glicerol proporcionado pela interesterificação possa modular as concentrações circulantes de LDL pela regulação de enzimas-chave envolvidas no metabolismo do colesterol.

\subsubsection{Estudos em humanos}

Em humanos, tanto o óleo de soja parcialmente hidrogenado quanto o interesterificado proporcionaram aumento na razão LDL-c/HDL-c quando comparados ao óleo de palma. Além da alteração nas concentrações de lípides plasmáticos, a gordura interesterificada exerceu um efeito adverso sobre o metabolismo da glicose, reduzindo a concentração plasmática de insulina e aumentando a glicemia de jejum ${ }^{264}$. Quando, porém, comparado à margarina, contendo elevados teores de ácido linoleico e moderados de trans, o consumo de margarinas contendo óleo de palma (láurico, mirístico, palmítico, oleico e linoleico) ou óleo de palma interesterificado favoreceu o aumento nas concentrações de LDL-c em homens hipercolesterolêmicos ${ }^{265}$. Além disso, foi demonstrado que a interesterificação transferiu quantidades significativas de ácido palmítico para a posição sn-2 e de ácidos graxos insaturados (AGl) para as posições sn-1 e sn-3, o que foi refletido nos quilomícrons do plasma ${ }^{265}$. Geralmente, a posição sn-2 em óleos vegetais é ocupada por AGl e, de acordo com Wang e cols. ${ }^{266}$, inserir um SFA nessa posição pode prejudicar o metabolismo de LDL-c e, também, a atividade da lecitina colesterol aciltransferase (LCAT), enzima que transfere ésteres de colesterol presentes nas lipoproteínas circulantes no plasma para HDL-c ${ }^{267}$.

Outro estudo conduzido em mulheres demonstrou, no entanto, que o ácido palmítico nas posições sn-1 e sn-3 foi responsável pelo aumento na concentração plasmática de TG e na redução dos valores de insulina no início da resposta pós-prandial (0-90 min ${ }^{268}$, eventos que estão associados ao risco cardiovascular.

Com relação à influência dos tipos de interesterificação sobre o perfil de lipoproteínas ${ }^{269}$, verificou-se que a interesterificação química aumentou a concentração pós-prandial de TG (85\%) em indivíduos obesos, fato não observado em eutróficos, sugerindo que a interesterificação pode afetar indivíduos saudáveis de maneira diferente daqueles que já têm um risco para desenvolver DCV e diabetes mellitus tipo 2.

Em indivíduos saudáveis, a interesterificação química não alterou as concentrações plasmáticas de lipídeos, mas favoreceu a menor concentração do dímero $D$, um produto de degradação da fibrina associado com o risco para doença cardiovascular ${ }^{270}$.

Em suma, até o presente momento, não há evidências científicas que permitam concluir o efeito do rearranjo de ácidos graxos na gordura interesterificada sobre parâmetros metabólicos e de desenvolvimento da aterosclerose e desfecho cardiovascular. Contudo, cabe ressaltar que há grande predominância de ácidos graxos saturados na gordura interesterificada de utilização industrial.

\begin{tabular}{lcc}
\hline Recomendação & $\begin{array}{c}\text { Grau de } \\
\text { recomendação }\end{array}$ & $\begin{array}{c}\text { Nível de } \\
\text { evidência }\end{array}$ \\
\hline $\begin{array}{l}\text { O consumo de gordura } \\
\text { interesterificada pode alterar lípides } \\
\text { plasmáticos, e mais estudos são } \\
\text { necessários para conclusões da ação } \\
\text { dessa gordura sobre metabolismo dos } \\
\text { humanos. }\end{array}$ & \|lb & B \\
\hline
\end{tabular}

\section{Utilização prática do ácido graxo da dieta com base em evidências}

A composição nutricional de uma dieta varia de acordo com os objetivos propostos para cada indivíduo e de fatores socioeconômicos e culturais, tendo sempre como base diretrizes nutricionais cientificamente fundamentadas. Dessa forma, esta Diretriz traz dois modelos dietéticos (anexo) com o objetivo de exemplificar o alcance das recomendações nutricionais aqui discutidas. Cabe ressaltar que são apenas exemplos dietéticos gerais e, portanto, devem ser ajustados de acordo com as necessidades individuais e as características peculiares de cada região do Brasil.

O modelo dietético 1 compreende uma dieta de $2.000 \mathrm{Kcal}$, com recomendação mínima de $25 \%$ do valor calórico total (VCT) em lípides totais, teor de ácidos graxos saturados menores do que 7\% do VCT e equilíbrio entre ácidos graxos monoinsaturados, poli-insaturados, Ômega-3 e Ômega-6, além de colesterol total. O modelo 2 compreende igualmente 2.000 
Kcal, porém com a recomendação máxima de 35\% do VCT em lípides, teor de ácidos graxos saturados entre 7\%-10\% do VCT e adequação dos demais lípides preconizados nesta Diretriz.

Diversas são as estratégias nutricionais capazes de compor o modo de ação para a manutenção da saúde cardiovascular ou a redução do risco de danos cardiovasculares. Entre elas encontrase a dieta propriamente dita, com o incentivo ao consumo de alimentos saudáveis como os ricos em ácidos graxos Ômega- $3^{271}$, maior teor de grãos integrais, distribuição racional de vitaminas e minerais, enfatizando-se a redução do conteúdo de sódio ${ }^{272}$. Além disso, a substituição pontual de alimentos ricos em gorduras prejudiciais por outros com perfis mais adequados no que tange a seus conteúdos de ácidos graxos tem sido adotada como prática eficaz ${ }^{273}$. Contudo, quando se trata de gorduras, diferentemente de outros macronutrientes, deve-se destinar atenção especial para o modo de conservação e manipulação desses alimentos, a fim de preservar ao máximo suas propriedades benéficas e de evitar alterações químicas em suas estruturas, capazes de aumentarem ainda mais o risco de eventos cardiovasculares ${ }^{274,275}$. A importância da conservação da estrutura dos ácidos graxos nos alimentos tem se tornado atualmente um capítulo à parte nas estratégias de ações nutricionais.

\subsection{Modo de conservação, manipulação e preparo dos alimentos ricos em gorduras mono e poli-insaturadas e} suas fontes alimentares

Alimentos ricos em lipídios que apresentam insaturações em sua composição química necessitam de cuidados especiais em seu manuseio, de forma que a preservação das características saudáveis desses alimentos seja mantida. As duplas ligações que caracterizam a denominação "insaturação" desses lipídios são ligações extremamente sensíveis a diversas condições físico-químicas como temperaturas elevadas ${ }^{275}$, exposição a luz e oxigênio ${ }^{276}$. A desestabilização e oxidação dessas insaturações culminam com o surgimento e incorporação de isômeros trans nesses alimentos ${ }^{277-279}$. Com características potencialmente deletérias 280,281 , ações alternativas têm sido elaboradas para minimizar ao máximo a ocorrência desse fenômeno. Tais precauções devem estar presentes desde a aquisição desses produtos no mercado até o momento de serem manipulados e, posteriormente, armazenados.

\subsection{Aquisição dos produtos no mercado}

Óleos e gorduras de origem vegetal apresentam, naturalmente, quantidades importantes das vitaminas lipossolúveis A e E, capazes de auxiliar na estabilização química desses óleos ${ }^{282,283}$. Contudo, quanto maior a presença de ácidos graxos insaturados no alimento, maior a chance de oxidação e peroxidação desses lipídios, mesmo com a presença dessas importantes vitaminas ${ }^{284,285}$.

Óleos como os de soja, milho, girassol, canola e amendoim apresentam razoável estabilidade quando mantidos sob temperaturas abaixo de $25^{\circ} \mathrm{C}$, mesmo depois de abertos pelo consumidor, pois são estabilizados pelas vitaminas lipossolúveis. Outros óleos, como os de linhaça, açafrão, gergelim e prímula, extremamente ricos em ácidos graxos poli-insaturados, necessitam de cuidados extras. Geralmente comercializados em embalagens protegidas da luz (frascos âmbar), devem ainda ser armazenados, depois de abertos, dentro de geladeiras e bem vedados, protegendo-os então da temperatura e do oxigênio, respectivamente ${ }^{274-276}$. Os óleos de oliva (azeite), por exemplo, são comumente comercializados em frascos do tipo âmbar, mesmo não sendo fontes especiais de ácidos graxos poli-insaturados e, portanto, mais estáveis às alterações anteriormente descritas. Contudo, no caso dos azeites extravirgem, a luz pode rapidamente danificar os especiais compostos fenólicos presentes nesses óleos, os quais apresentam importantes características funcionais especialmente relacionadas às atividades antioxidantes ${ }^{284,286}$.

\subsection{Manipulação}

Especial atenção deve ser dada à semente de linhaça ou ao seu óleo. A semente de linhaça vem sendo cada vez mais consumida pelo seu teor importante de ácidos graxos Ômega-3 (C18:3 - alfalinolênico ${ }^{286}$. A linhaça marrom apresenta em sua composição um conteúdo aproximado de 58\% de ácidos graxos Ômega- ${ }^{3287,288}$. Em razão desse elevado teor e da presença de três insaturações nessa molécula, o Ômega-3 é alvo de interferentes exógenos ao organismo (luz, temperatura e oxigênio) ${ }^{275,276}$ e endógenos (espécies reativas de oxigênio) ${ }^{289}$, alterações que reduzem de forma significante sua atividade e o tornam potencialmente deletério ao organismo. Mesmo sendo essa semente e, consecutivamente, seu óleo ricos em vitamina $\mathrm{E}^{290,291}$, é um erro tal óleo ser comercializado em frascos transparentes, como comumente se observa. Caso seja necessário o consumo de óleo de linhaça, a orientação é procurar por frascos do tipo âmbar e posteriormente armazená-los em geladeira, além de devidamente vedados.

Ainda, outra forma de comercialização da semente de linhaça é a sua forma triturada. É certo que o ácido graxo Ômega-3 contido nessa semente está localizado no seu interior, mais especificamente em seu gérmen. Para acessar essa substância, o gérmen deve ser exposto; contudo, apenas a ação mecânica da mastigação é insuficiente, tendo sido comum adotar a trituração como alternativa. Isso ocorre pela resistência à sua capa celulósica às enzimas intestinais, permanecendo inalterada e eliminada integralmente. A linhaça triturada normalmente encontrada em supermercados é armazenada em embalagens plásticas transparentes e em contato direto com a luz ultravioleta da iluminação artificial dos ambientes. Além disso, infelizmente não é possível saber ou garantir o método de trituração adotado pela indústria, e nem sobre quanto tempo essa semente ficou exposta a luz e oxigênio antes de ser embalada. Portanto, deve-se adotar um olhar cauteloso sobre esse produto.

A recomendação aqui adotada é para a aquisição da semente em seu estado bruto, e nunca triturada. A trituração pode ser feita por meio de liquidificador, mixer ou pilões tradicionais. Contudo, deve-se rapidamente armazenar esse pó em frascos plásticos opacos (abrigando-se da luz), adequadamente tampados (abrigando-se do oxigênio) e mantidos sob congelador (preferencialmente) ou geladeira (abrigando-se da temperatura). No momento de sua utilização, deve-se retirar apenas a quantidade desejada para uso e abrigá-la novamente. Caso não seja possível seguir tais recomendações, orientamos veementemente a não utilização desse produto triturado. O consumo de um lipídio oxidado ou rancificado pode ser extremamente deletério ao organismo ${ }^{291}$.

\subsection{Preparo de alimentos}

Com exceção da utilização de óleos para a composição de alimentos frios como saladas, toda a forma de cocção deve levar em conta as seguintes orientações: 


\subsubsection{Do cozimento em água}

Óleos utilizados para a cocção de alimentos refogados em água fervente como arroz, feijão, soja, legumes, etc. apresentam em geral boa resistência às alterações químicas e físicas. A temperatura de cocção em sistema aberto $\left(100^{\circ} \mathrm{C}\right)$ ou fechado (pressão a $120^{\circ} \mathrm{C}$ ) é insuficiente para isomerização ou oxidação das moléculas de ácidos graxos ${ }^{292,293}$. O tempo de cocção é um importante fator delimitador; contudo, alterações não têm sido observadas em cocções em água nas temperaturas descritas aqui. Ácidos graxos monoinsaturados como os encontrados no azeite de oliva são estáveis a esse tipo de cocção; entretanto, mais uma vez, as propriedades fenólicas encontradas nos azeites extravirgem são bastante reduzidas e prejudicadas mesmo sob temperaturas brandas, em geral, acima de $80^{\circ} \mathrm{C}^{294,295}$.

\subsubsection{Do cozimento em óleo}

É sabido que o método de fritura é capaz de atingir fácil e rapidamente temperaturas elevadas. Dependendo da temperatura, o óleo se oxida e é capaz de agregar a si compostos tóxicos, capazes de descaracterizarem por completo o objetivo proposto, que é a cocção com qualidade ${ }^{274}$. A ausência de equipamentos técnicos para a mensuração da qualidade ou temperatura dos modos de cocção nas casas é um fator complicador para a manutenção dessa qualidade; contudo, algumas alternativas de ordem prática podem ser adotadas a fim de se evitar o comprometimento dos alimentos.

O ponto de fumaça é uma característica crucial que marca o surgimento de compostos tóxicos no óleo, além de ser indicativo da isomerização e oxidação dos ácidos graxos ${ }^{295}$. Tal ponto oscila com cada tipo de óleo, que pode variar entre $120^{\circ} \mathrm{C}$ e $230^{\circ} \mathrm{C}$ como temperatura de início. Comumente adota-se em média $150^{\circ} \mathrm{C}$ como temperatura segura para frituras. Entretanto, tal temperatura pode ser insuficiente para fritar determinados alimentos. A fritura de verduras encontra-se adequada entre $160^{\circ} \mathrm{C}$ e $165^{\circ} \mathrm{C}$. A temperatura indicada para a maioria das frituras encontra-se entre $170^{\circ} \mathrm{C}$ e $175^{\circ} \mathrm{C}^{275}$. Acima de $180^{\circ} \mathrm{C}$ a temperatura é tida como alta e já traz grandes consequências para o óleo $274,275,296$. A forma caseira de se verificar temperatura aproximada do óleo é a seguinte: toma-se um pedaço pequeno de pão, juntamente ao óleo na frigideira. Se o pão foi ao fundo e não subiu, a temperatura deve estar entre $150^{\circ} \mathrm{C}$. Se o pão foi ao fundo e subiu lentamente, a temperatura está entre $160^{\circ} \mathrm{C}$ e $165^{\circ} \mathrm{C}$. Se o pão foi ao fundo e rapidamente chegou à superfície, está entre $170^{\circ} \mathrm{C}$ e $175^{\circ} \mathrm{C}$. Caso o pão se queime, e não se afunde, a temperatura está alta $\left(>180^{\circ} \mathrm{C}\right)$.

De modo geral recomenda-se o aquecimento do óleo em fogo moderado e nunca alto. Orienta-se para que, de forma alguma, se fumegue o óleo, com o objetivo de não alcançar o ponto de fumaça. Recomenda-se a não reutilização do óleo aquecido. Além disso, mesmo filtrando-se posteriormente ao uso, pequenos fragmentos de alimentos são capazes de acelerar sua degradação.

Os óleos de palma e dendê são estáveis para frituras; contudo, possuem alto teor de ácidos graxos saturados, os quais são prejudiciais à saúde, devendo-se recorrer a alternativas ${ }^{293}$.
Os óleos adequados para o cotidiano de frituras são os de soja e canola, com quantidades semelhantes de ácidos graxos mono e poli-insaturados em sua composição $^{275}$. Recentemente o INMETRO analisou a composição de lipídeos e a influência do aquecimento em três tipos de azeite de oliva (extravirgem, mistura de virgem com refinado e mistura de extravirgem com refinado) com variados percentuais de acidez e de diversas procedências $^{297}$. Os resultados demonstraram que não houve variação significativa no perfil de ácidos graxos saturados, monoinsaturados e poli-insaturados Ômega-3 e Ômega-6 do azeite de oliva extravirgem e nas misturas de azeite de oliva quando submetidos à temperatura de $170^{\circ} \mathrm{C}$ por 10 e 30 minutos. Também não foi detectada diferença no perfil lipídico entre as amostras de azeite de oliva extravirgem orgânicos e não orgânicos.

Segundo posicionamento da ANVISA, no entanto, a análise de azeite de oliva aquecido pelo INMETRO verificou apenas o óleo isoladamente e não a combinação de alimento + azeite aquecido, sabidamente um dos fatores que podem potencializar a reação de oxidação quando se submete o óleo ao aquecimento ${ }^{297}$.

\subsection{Fontes}

As recomendações nutricionais de macronutrientes destinadas a indivíduos saudáveis variam muito pouco de acordo com a literatura científica, o que não ocorre com indivíduos portadores de enfermidades específicas. Independentemente da estratégia nutricional, se com baixo ou alto teor de lipídeos, por exemplo, é fundamental que sejam selecionadas fontes alimentares adequadas de ácidos graxos; igualmente importante é o cuidado quanto ao modo de preparo e armazenamento dessas fontes alimentares para o cumprimento dos objetivos propostos.

Ácidos graxos poli-insaturados como os da série Ômega-6 e os saturados ocorrem amplamente na natureza, portanto é necessário cuidado extra para que seu consumo não seja extrapolado. Gorduras saturadas são necessárias ao organismo para funções estruturais e energéticas; entretanto, o consumo excessivo de ácidos graxos saturados pode trazer riscos ao organismo, como discutido anteriormente nesta Diretriz. Já os ácidos graxos Ômega-6 são lípides essenciais à saúde, sendo necessário adquiri-los por meio de fontes alimentares, uma vez que o organismo é incapaz de sintetizá- $\operatorname{los}^{298}$. Sua característica poli-insaturada garante diversos benefícios ao organismo, desde que dentro dos limites recomendados de consumo. De acordo com a literatura, proporções de Ômega-6 e Ômega-3 são estabelecidas como benéficas, garantindo equilíbrio químico e fisiológico ao organismo ${ }^{298}$. Quantidades desbalanceadas da razão Ômega-6 / Ômega-3 (acima de 7:1) podem exercer grandes danos à saúde, como o agravamento de processos inflamatórios de características subclínicas que caracterizam atualmente a obesidade ${ }^{299-306}$. Esse processo inflamatório sistêmico, de baixo grau, predispõe também os indivíduos ao surgimento de doenças como a aterosclerose ${ }^{307-309}$, uma vez que esse fenômeno se constitui num dos pilares para o início do processo de aterogênese que ocorre no endotélio vascular. 
Alimentos de origem animal são ricos em gorduras saturadas, e, portanto, até mesmo peixes devem ser observados nesse intuito $^{288,297,310}$. Já os alimentos de origem vegetal são, em geral, fontes de ácidos graxos insaturados, com prevalência significativa em Ômega-6. Alimentos como os óleos de milho, girassol, algodão, gergelim, cártamo e prímula são fontes quase exclusivas de Ômega- $6^{311}$. Deve-se ressaltar ainda que são diversos os produtos derivados desses óleos, como margarinas, maioneses e atualmente os azeites compostos (mistura de óleo de oliva e óleos de girassol ou milho). Ainda como fontes importantes de Ômega-6 compreendem as nozes e sementes oleaginosas em geral, como noz, castanha-do-brasil, castanha de caju, amêndoa, avelã etc.

Alimentos de origem vegetal considerados fontes de Ômega-3 são de ocorrência rara na natureza. Isso requer atenção, uma vez que os ácidos Ômega-3 são também essenciais ao organismo humano ${ }^{298}$. Os representantes vegetais desses lípides são a soja (5\% a 7\%), a canola (7\% a $10 \%$ ) e a semente de linhaça (58\% a $60 \%$ ) - Figura $1.3275,288$. Contudo, é salientado que o Ômega-3 encontrado nesses vegetais é o ácido alfalinolênico (C18:3), o qual pode ser convertido nos principais representantes da classe, EPA (eicosapentaenoico) e DHA (docosa-hexaenoico). A conversão em tais ácidos é baixa, devendo-se dar prioridade para o consumo de Ômega-3 proveniente de fontes animais, e assim obtendo-se diretamente os ácidos EPA e DHA ${ }^{298,312,313}$. Entretanto, uma incongruência é notada neste tópico, uma vez que a grande quantidade de Ômega-3 encontrada em peixes não se verifica significativamente disponível ou, sequer, presente no filé - Figura 1. ${ }^{1288,297,314}$, portanto, na parte comumente comestível pelas populações ocidentais ${ }^{315}$.

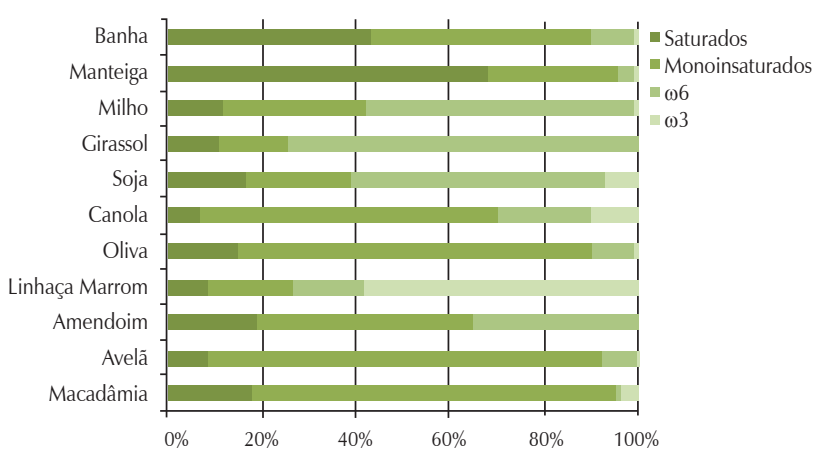

Figura 1 - Perfil de ácidos graxos no óleo do filé de peixes da costa brasileira $^{297}$.

Sendo os peixes, invariavelmente, a primeira opção profilática ou da terapêutica dietética amplamente recomendada por profissionais de saúde, compreendemos que cabe neste documento um direcionamento específico sobre tal conduta, no intuito de clarificar a melhor forma de fazê-lo.

\section{6. Ômega-3 em peixes de água fria}

Entre os anos 1980 e 1990, o aumento do consumo de peixes foi fortemente atrelado à redução do risco de desenvolvimento de doenças cardiovasculares, especialmente os eventos ligados a aterosclerose e reincidências pós-infarto ${ }^{316-319}$. No entanto, a maioria dos trabalhos faz retrato sobre o consumo de óleo de peixe, e atribui ao peixe, na forma de alimento, os benefícios encontrados. É certo que a inclusão do peixe em detrimento a outros tipos de carne é capaz de promover benefícios à saúde humana, especialmente pelo fato de ser uma carne magra $^{320}$. Sendo uma carne magra, por melhor que seja o perfil de ácidos graxos do óleo desse peixe em relação aos ácidos graxos Ômega-3, a quantidade de gordura a ser ingerida é pequena, se fornecida apenas pelo filé. Existe exceção para alguns peixes classificados como gordos como demonstram as tabelas brasileiras de composição de alimentos ${ }^{321}$ e outras referências ${ }^{288,297}$; contudo, não são os que apresentam os melhores conteúdos de ácidos do tipo Ômega-3.

Ainda são conflitantes os estudos que tentam apontar melhorias conquistadas pela mudança de hábito alimentar relacionada ao aumento do consumo de peixes e a tentativa de atrelar esse consumo ao aumento da ingestão de Ômega-3. É possível que esses conflitos ocorram justamente pela enorme variedade de peixes estudados, incluindo a diferença entre espécies, se são de vida livre (selvagem) ou não (cativeiro) ${ }^{322}$, água doce ou salgada ${ }^{323}$, se em fase de desova ${ }^{324}$ e, especialmente, baseado nas dietas que consomem ${ }^{325}$. Outro fator capaz de exercer grandes variações sobre o acúmulo de lípides em peixes é o tamanho do animal, pois peixes mais velhos e, portanto, mais pesados acumulam mais gorduras em seus tecidos. De qualquer forma, parece haver mecanismos evolutivos e de sobrevivência que direcionam maior acúmulo de ácidos graxos Ômega-3 para tecidos como cérebro ${ }^{326}$, fígado ${ }^{327-330}$ ovas $^{324}$ e olhos $^{329,331}$ dos peixes de água fria. Não obstante, um dos produtos comumente encontrados em mercados e farmácias, como referência de grande possuidor de tais ácidos, é o óleo de fígado de bacalhau, na forma de emulsão.

Sendo o fator dietético/ração o principal responsável pela conquista e acúmulo de ácidos Ômega-3 em peixes, uma vez que esses animais não possuem a capacidade de sintetizá-los, torna-se necessária a observação cuidadosa desse quesito. Houve grande aumento na demanda mundial de consumo de peixes e, consecutivamente, a necessidade de aumento em sua produção. Diante disso, e longe da vida livre, a fonte primária de acesso a tais ácidos é a ração industrializada. Em razão do alto custo, foram criadas alternativas à adição de óleo de peixe nessas rações, como a suplementação a partir dos óleos de soja, canola e linhaça, uma vez que o peixe é capaz de derivar competentemente o ácido alfalinolênico em EPA e DHA, diferentemente dos humanos.

Uma série de trabalhos demonstra a baixa incorporação de gorduras totais em músculo de peixes de água fria ${ }^{334}$, o que reforça a ideia de serem peixes magros. Recentemente o INMETRO demonstrou um trabalho no qual encontrou também baixa quantidade de gordura em partes comestíveis pela população em geral, de peixes da costa brasileira ${ }^{297}$. Contudo, enfatiza-se que não há dúvidas de que o perfil de ácidos graxos Ômega-3 dos peixes é excelente. Mas é preciso que haja quantidade suficiente de gordura na carne desses animais para que as recomendações nutricionais sejam alcançadas, bem como os efeitos benéficos desses ácidos graxos.

O intuito desta reflexão sobre a quantidade de gordura em peixes de água fria é atentarmos para o fato de que esses peixes possuem um ótimo perfil de ácidos graxos Ômega-3, como já 
dito; contudo, muitas vezes esse conteúdo pode estar em locais pouco consumidos pela população em geral, como cérebro, fígado e vísceras, regiões que apresentam grandes quantidades de gordura, justificando, por sua vez, a qualificação de "peixes gordos" aos salmões, arenques, bacalhaus, anchovas, entre outros, como comumente observamos em diversos estudos apontados neste documento. Quando extraídas essas gorduras e analisadas como um todo, apresentam um perfil excelente de ácidos Ômega-3; contudo, não são todas as populações que consomem cérebro e fígado de peixes.

\section{7. Ômega-3 em peixes em geral}

Mesmo sendo o filé fonte restrita de Ômega 3, o seu consumo é incentivado, uma vez que, além de ser uma carne magra (Figura 3) 297 , é fonte de proteínas de altíssimo valor biológico, como também de micronutrientes. Dessa forma, sugere-se como alternativa à incongruência apontada o consumo de peixes associado ao consumo de vegetais ricos em Ômega-3, o que suplantará de forma eficaz qualquer deficiência, desde que também respeitados os limites de ingestão de Ômega-6.

A figura 3 mostra diversos peixes encontrados na costa brasileira ou no comércio em geral, como é o caso da truta.

Tais peixes apresentam pouca gordura presente em seus músculos, no caso, o filé. O peixe com o maior teor de gordura é o Filhote, com aproximadamente $10 \%$; no entanto, desse total, apresenta aproximadamente $50 \%$ na forma de ácidos graxos saturados. O peixe que apresenta o melhor perfil de ácidos graxos é a Pescadinha, que possui a menor quantidade de ácidos saturados em sua composição e a melhor relação w-6:w-3. Contudo, um filé de 100 g é capaz de trazer apenas $1 \%$ de Ômega- $3^{297}$.

Nas figuras 1 e 2 encontram-se alguns exemplos de alimentos preparados e in natura respectivamente e seus respectivos perfis de ácidos graxos saturados, monoinsaturados e poli-insaturados (Ômega-3 e 6).

De forma prática, recomendamos que, para a confecção de dietas balanceadas em ácidos graxos Ômega-6 e 3, tais cálculos devam levar em conta a quantidade específica de cada ácido

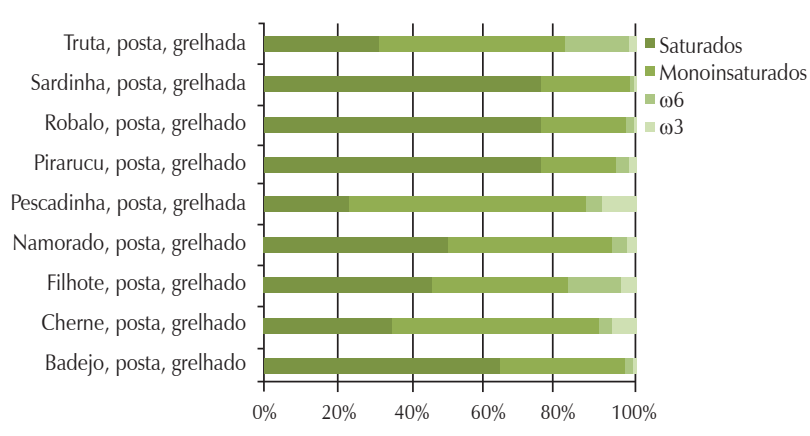

*Informações obtidas dos rótulos dos produtos afixados nas embalagens.

Figura 2 - Perfil de ácidos graxos dos principais óleos e gorduras consumidos pela população.

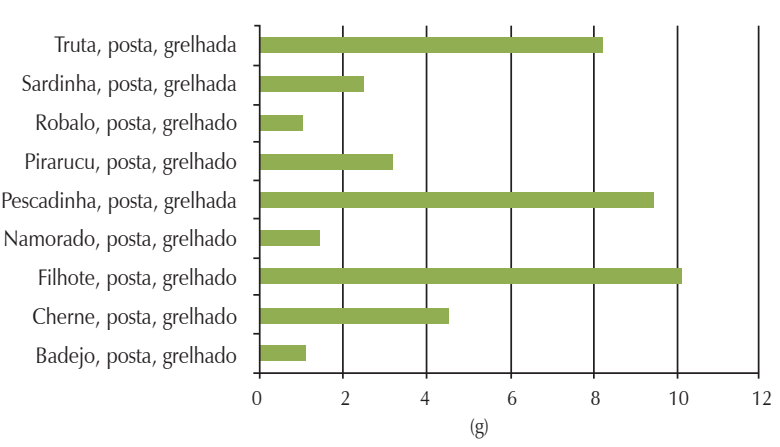

Figura 3 - Quantidade total de gordura encontrada em $100 \mathrm{~g}$ de filé de peixe. Peixes comumente encontrados na costa brasileira ${ }^{297}$

graxo em gramas, em vez de ater-se apenas à razão w-6:w-3. Conforme discutido neste documento, no item que se refere aos "ácidos graxos Ômega-6", o mais adequado seria não apenas tomarmos como base as quantidades totais de w- 6 e w-3, mas também, a razão entre suas proporções, que serviram como método de simples conferência ou orientação para o cálculo de uma dieta, assim como demonstrado na figura 4.

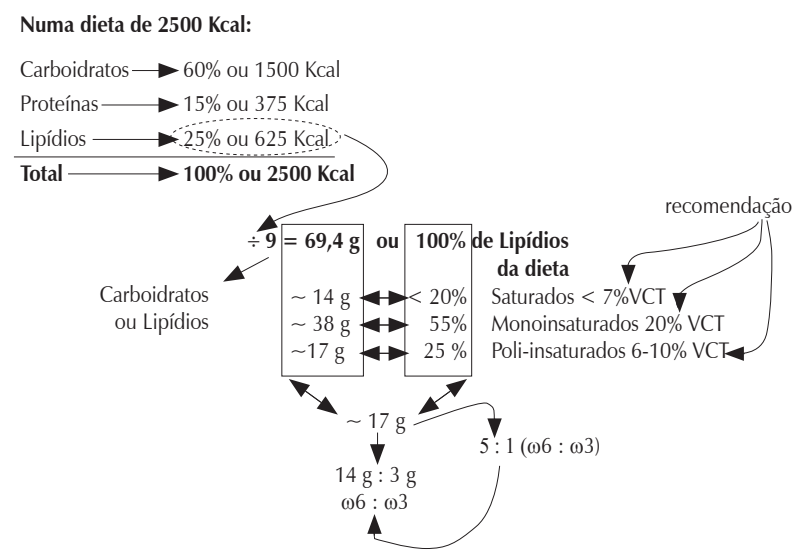

Figura 4 - Exemplo de uma dieta de $2.500 \mathrm{Kcal}$ e a forma pela qual é possível verificar a adequação das quantidades de Ômega-6 e 3 em relação à proporção de 5:1 desses ácidos graxos respectivamente.

Nota: Numa dieta de $2.500 \mathrm{Kcal}, 625 \mathrm{Kcal}$ correspondem a $25 \%$ das calorias da dieta. Esse valor pode ser convertido em gramas de gordura ao dividi-lo por 9 Kcal. Sendo então 69,4 g correspondentes ao conteúdo total de gordura da dieta (100\%), necessita-se apenas distribuir tal valor entre o que é preconizado neste documento em relação aos lípides de origem saturada $(<20 \%)$, monoinsaturada $(55 \%)$ e poliinsaturada (25\%). Sendo ambos os ácidos graxos Ômega-6 e Ômega-3 poli-insaturados, basta realizar a distribuição desses $25 \%$ entre as proporções de w-6 e w-3. Sendo então esses $25 \%$ correspondentes a 17 gramas de poliinsaturados aproximadamente, então, dentro da proporção recomendada para simples conferência da dieta, temos que 14 g de Ômega-6 e 3 g de Ômega-3 encontram-se distribuídos proporcionalmente dentro do recomendado, ou seja, cinco partes de ácidos graxos Ômega-6 para uma parte de ácidos graxos Ômega-3. 


\section{Diretrizes}

Dieta 1 - Exemplo para $2000 \mathrm{Kcal}$ a partir de $25 \%$ de lipídios ${ }^{335,336}$.

\begin{tabular}{|c|c|c|c|}
\hline Refeições & Alimentos & $\begin{array}{c}\text { Quantidade } \\
\text { (medidas caseiras) }\end{array}$ & $\begin{array}{c}\text { Quantidade } \\
\text { (g) }\end{array}$ \\
\hline \multirow[t]{7}{*}{ Desjejum } & Leite desnatado & 1 xícara (de chá) & $200 \mathrm{~mL}$ \\
\hline & Café & 1 xícara pequena & $50 \mathrm{~mL}$ \\
\hline & Açúcar & $\begin{array}{c}1 \text { colher (de chá) } \\
\text { cheia }\end{array}$ & $5 \mathrm{~g}$ \\
\hline & Pão com fibras (aveia) & 2 fatias & $50 \mathrm{~g}$ \\
\hline & $\begin{array}{c}\text { Creme vegetal } \\
(0 \% \text { gordura trans) }\end{array}$ & $\begin{array}{c}1 \text { colher (de chá) } \\
\text { cheia }\end{array}$ & $8 \mathrm{~g}$ \\
\hline & Mamão & 1 fatia média & $170 \mathrm{~g}$ \\
\hline & Linhaça & 1 colher (de sopa) & $10 \mathrm{~g}$ \\
\hline $\begin{array}{l}\text { Lanche } \\
\text { da manhã }\end{array}$ & Suco de laranja & $\begin{array}{c}1 \text { copo (tipo } \\
\text { requeijão) cheio }\end{array}$ & $250 \mathrm{~mL}$ \\
\hline \multirow[t]{12}{*}{ Almoço } & Arroz & $\begin{array}{c}5 \text { colheres (de sopa) } \\
\text { cheias }\end{array}$ & $100 \mathrm{~g}$ \\
\hline & Feijão & $\begin{array}{c}3 \text { colheres (de sopa) } \\
\text { cheias }\end{array}$ & $51 \mathrm{~g}$ \\
\hline & $\begin{array}{c}\text { Frango (filé) com } \\
\text { legumes refogados }\end{array}$ & & \\
\hline & frango (filé) & $\begin{array}{c}21 / 2 \text { colheres } \\
\text { (de sopa) }\end{array}$ & $50 \mathrm{~g}$ \\
\hline & cenoura & $\begin{array}{c}3 \text { colheres (de sopa) } \\
\text { cheias }\end{array}$ & $75 \mathrm{~g}$ \\
\hline & brócolis & $\begin{array}{c}4 \text { colheres (de sopa) } \\
\text { cheias }\end{array}$ & $60 \mathrm{~g}$ \\
\hline & Salada de folhas & & \\
\hline & alface & 3 folhas médias & $30 \mathrm{~g}$ \\
\hline & repolho & $\begin{array}{c}3 \text { colheres (de sopa) } \\
\text { cheias }\end{array}$ & $30 \mathrm{~g}$ \\
\hline & Azeite de oliva & $\begin{array}{l}11 / 2 \text { colher } \\
\text { (de sopa) }\end{array}$ & $12 \mathrm{~mL}$ \\
\hline & Óleo de soja (preparo) & $\begin{array}{c}1 \text { colher } \\
\text { (de sobremesa) }\end{array}$ & $5 \mathrm{~mL}$ \\
\hline & Abacaxi & 1 fatia grossa & $190 \mathrm{~g}$ \\
\hline \multirow[t]{4}{*}{$\begin{array}{l}\text { Lanche } \\
\text { da tarde }\end{array}$} & logurte desnatado & $1 / 2$ unidade & $100 \mathrm{~mL}$ \\
\hline & Maçã & 1 unidade pequena & $80 \mathrm{~g}$ \\
\hline & $\begin{array}{c}\text { Torrada de pão de } \\
\text { forma integral }\end{array}$ & 2 fatias & $50 \mathrm{~g}$ \\
\hline & Geléia & 4 colheres (de chá) & $\begin{array}{l}2 \text { colh. } \\
\text { (de chá)/fatia }\end{array}$ \\
\hline \multirow[t]{12}{*}{ Jantar } & Arroz & $\begin{array}{c}3 \text { colheres (de sopa) } \\
\text { cheias }\end{array}$ & $60 \mathrm{~g}$ \\
\hline & $\begin{array}{l}\text { Feijão ou lentilha ou } \\
\text { ervilha }\end{array}$ & $\begin{array}{l}2 \text { colheres (de sopa) } \\
\text { cheias }\end{array}$ & $40 \mathrm{~g}$ \\
\hline & $\begin{array}{l}\text { Sardinha assada com } \\
\text { batata e cebola }\end{array}$ & & \\
\hline & sardinha & 3 unidades médias & $75 \mathrm{~g}$ \\
\hline & batata & $\begin{array}{l}4 \text { colheres de sopa } \\
\text { (cheias) }\end{array}$ & $120 \mathrm{~g}$ \\
\hline & cebola & 1 unidade média & $70 \mathrm{~g}$ \\
\hline & Couve refogada & $\begin{array}{c}2 \text { colheres (de sopa) } \\
\text { cheias }\end{array}$ & $40 \mathrm{~g}$ \\
\hline & Salada de tomate & 1 unidade pequena & $50 \mathrm{~g}$ \\
\hline & Azeite de oliva & $\begin{array}{c}11 / 2 \text { colher (de } \\
\text { sopa) }\end{array}$ & $12 \mathrm{~mL}$ \\
\hline & Óleo de soja (preparo) & $\begin{array}{c}1 \text { colher } \\
\text { (de sobremesa) }\end{array}$ & $5 \mathrm{~mL}$ \\
\hline & Mexerica & 1 unidade pequena & $100 \mathrm{~g}$ \\
\hline & Doce de goiaba & $\begin{array}{l}1 \text { colher (de sopa) } \\
\text { rasa }\end{array}$ & $30 \mathrm{~g}$ \\
\hline
\end{tabular}

Dieta 2 - Exemplo para $2000 \mathrm{Kcal}$ a partir de $35 \%$ de lipídios ${ }^{33,336}$.

\begin{tabular}{|c|c|c|c|}
\hline Refeições & Alimentos & $\begin{array}{c}\text { Quantidade } \\
\text { (medidas caseiras) }\end{array}$ & $\begin{array}{c}\text { Quantidade } \\
\text { (g) }\end{array}$ \\
\hline \multirow[t]{7}{*}{ Desjejum } & Leite desnatado & 1 xícara (de chá) & $200 \mathrm{~mL}$ \\
\hline & Café & 1 xícara pequena & $50 \mathrm{~mL}$ \\
\hline & Açúcar & $\begin{array}{c}1 \text { colher (de chá) } \\
\text { cheia }\end{array}$ & $5 \mathrm{~g}$ \\
\hline & Pão com fibras (aveia) & 2 fatias & $50 \mathrm{~g}$ \\
\hline & $\begin{array}{c}\text { Creme vegetal }(0 \% \\
\text { gordura trans) }\end{array}$ & $\begin{array}{c}1 \text { colher (de chá) } \\
\text { cheia }\end{array}$ & $8 \mathrm{~g}$ \\
\hline & Mamão & 1 fatia média & $170 \mathrm{~g}$ \\
\hline & Linhaça triturada & 1 colher (de sopa) & $10 \mathrm{~g}$ \\
\hline $\begin{array}{l}\text { Lanche da } \\
\text { manhã }\end{array}$ & Suco de laranja & $\begin{array}{l}1 \text { copo (tipo } \\
\text { requeijão) cheio }\end{array}$ & $250 \mathrm{~mL}$ \\
\hline \multirow[t]{13}{*}{ Almoço } & Arroz & $\begin{array}{c}4 \text { colheres (de sopa) } \\
\text { cheias }\end{array}$ & $80 \mathrm{~g}$ \\
\hline & Feijão & $\begin{array}{c}3 \text { colheres (de sopa) } \\
\text { cheias }\end{array}$ & $51 \mathrm{~g}$ \\
\hline & $\begin{array}{l}\text { Frango (filé) com } \\
\text { legumes refogados }\end{array}$ & & \\
\hline & frango (filé) & $\begin{array}{c}31 / 2 \text { colheres } \\
\text { (de sopa) }\end{array}$ & $75 \mathrm{~g}$ \\
\hline & berinjela & $\begin{array}{c}4 \text { colheres (de sopa) } \\
\text { cheias }\end{array}$ & $75 \mathrm{~g}$ \\
\hline & tomate & 1 unidade pequena & $50 \mathrm{~g}$ \\
\hline & cebola & $1 / 2$ unidade média & $35 \mathrm{~g}$ \\
\hline & Salada de folhas & & \\
\hline & alface & 3 folhas médias & $30 \mathrm{~g}$ \\
\hline & repolho & $\begin{array}{c}3 \text { colheres (de sopa) } \\
\text { cheias }\end{array}$ & $30 \mathrm{~g}$ \\
\hline & Azeite de oliva & $\begin{array}{c}11 / 2 \text { colher } \\
\text { (de sopa) }\end{array}$ & $12 \mathrm{~mL}$ \\
\hline & Óleo de soja (preparo) & $\begin{array}{c}1 \text { colher } \\
\text { (de sobremesa) }\end{array}$ & $5 \mathrm{~mL}$ \\
\hline & Abacaxi & 1 fatia grossa & $190 \mathrm{~g}$ \\
\hline \multirow[t]{5}{*}{$\begin{array}{l}\text { Lanche da } \\
\text { tarde }\end{array}$} & $\begin{array}{l}\text { Queijo fresco, tipo } \\
\text { minas }\end{array}$ & 2 fatias médias & $60 \mathrm{~g}$ \\
\hline & Azeite de oliva & 1 colher (de chá) & $2 \mathrm{~mL}$ \\
\hline & Noz & 1 unidade & $5 \mathrm{~g}$ \\
\hline & Banana nanica & 1 unidade grande & $90 \mathrm{~g}$ \\
\hline & $\begin{array}{l}\text { Torrada de pão de } \\
\text { forma integral }\end{array}$ & 1 fatia & $25 \mathrm{~g}$ \\
\hline \multirow[t]{11}{*}{ Jantar } & Arroz & $\begin{array}{c}3 \text { colheres (de sopa) } \\
\text { cheias }\end{array}$ & $60 \mathrm{~g}$ \\
\hline & $\begin{array}{c}\text { Grão-de-bico ou feijão } \\
\text { ou lentilha ou ervilha } \\
\text { ou soja }\end{array}$ & $\begin{array}{c}2 \text { colheres (de sopa) } \\
\text { cheias }\end{array}$ & $40 \mathrm{~g}$ \\
\hline & Atum em conserva & $\begin{array}{c}4 \text { colheres (de sopa) } \\
\text { cheias }\end{array}$ & $64 \mathrm{~g}$ \\
\hline & Espinafre refogado & $\begin{array}{c}1 \text { colher (de sopa) } \\
\text { cheia }\end{array}$ & $25 \mathrm{~g}$ \\
\hline & $\begin{array}{l}\text { Salada de pepino e } \\
\text { cenoura ralada }\end{array}$ & & \\
\hline & pepino & $\begin{array}{c}3 \text { colheres (de sopa) } \\
\text { cheias }\end{array}$ & $54 \mathrm{~g}$ \\
\hline & cenoura & $\begin{array}{c}4 \text { colheres (de sopa) } \\
\text { cheias }\end{array}$ & $48 \mathrm{~g}$ \\
\hline & Azeite de oliva & $\begin{array}{c}11 / 2 \text { colher } \\
\text { (de sopa) }\end{array}$ & $12 \mathrm{~mL}$ \\
\hline & Óleo de soja (preparo) & $\begin{array}{c}1 \text { colher } \\
\text { (de sobremesa) }\end{array}$ & $5 \mathrm{~mL}$ \\
\hline & Abacate & $\begin{array}{c}2 \text { colheres (de sopa) } \\
\text { cheias }\end{array}$ & $90 \mathrm{~g}$ \\
\hline & Açúcar & $\begin{array}{c}1 \text { colher (de chá) } \\
\text { cheia }\end{array}$ & $5 \mathrm{~g}$ \\
\hline
\end{tabular}




\section{Tabela Nutricional com quantidade de AG dos alimentos}

Composição de alimentos por 100 gramas de parte comestível: ácidos graxos ${ }^{99}$.

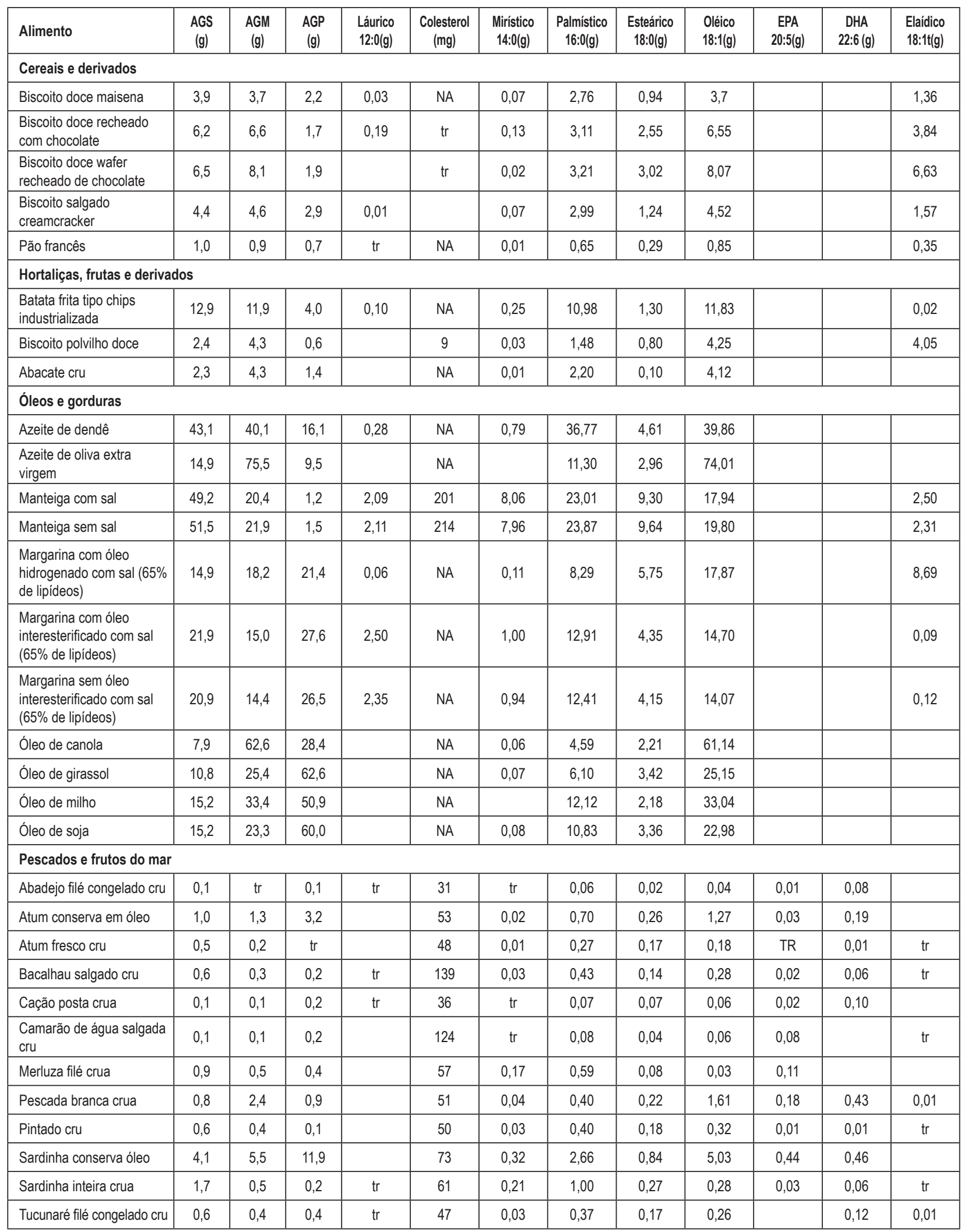




\section{Diretrizes}

\begin{tabular}{|c|c|c|c|c|c|c|c|c|c|c|c|c|}
\hline Alimento & $\begin{array}{l}\text { AGS } \\
(\mathrm{g})\end{array}$ & $\begin{array}{l}\text { AGM } \\
\text { (g) }\end{array}$ & $\begin{array}{l}\text { AGP } \\
\text { (g) }\end{array}$ & $\begin{array}{l}\text { Láurico } \\
\text { 12:0(g) }\end{array}$ & $\begin{array}{l}\text { Colesterol } \\
\text { (mg) }\end{array}$ & $\begin{array}{l}\text { Mirístico } \\
\text { 14:0(g) }\end{array}$ & $\begin{array}{l}\text { Palmístico } \\
\text { 16:0(g) }\end{array}$ & $\begin{array}{l}\text { Esteárico } \\
\text { 18:0(g) }\end{array}$ & $\begin{array}{l}\text { Oléico } \\
\text { 18:1(g) }\end{array}$ & $\begin{array}{l}\text { EPA } \\
20: 5(\mathrm{~g})\end{array}$ & $\begin{array}{c}\text { DHA } \\
22: 6(\mathrm{~g})\end{array}$ & $\begin{array}{l}\text { Elaídico } \\
18: 1 \mathrm{t}(\mathrm{g})\end{array}$ \\
\hline \multicolumn{13}{|l|}{ Carnes e derivados } \\
\hline $\begin{array}{l}\text { Contra filé com gordura } \\
\text { crua }\end{array}$ & 6,9 & 6,2 & 0,1 & 0,01 & 73 & 0,53 & 3,82 & 2,03 & 5,33 & & & 0,28 \\
\hline $\begin{array}{l}\text { Contra filé sem gordura } \\
\text { crua }\end{array}$ & 1,9 & 1,9 & 0,1 & & 59 & 0,12 & 1,05 & 0,58 & 1,66 & & & 0,06 \\
\hline $\begin{array}{l}\text { Coxão duro sem gordura } \\
\text { cru }\end{array}$ & 3,0 & 2,4 & 0,1 & & 60 & 0,21 & 1,66 & 0,98 & 2,12 & & & 0,01 \\
\hline $\begin{array}{l}\text { Coxão mole sem gordura } \\
\text { cru }\end{array}$ & 3,9 & 3,7 & 0,1 & & 84 & 0,29 & 2,34 & 1,06 & 3,23 & & & 0,12 \\
\hline Cupim cru & 6,8 & 6,4 & 0,2 & 0,01 & 51 & 0,46 & 3,80 & 2,06 & 5,56 & & & 0,30 \\
\hline Fígado cru & 3,0 & 1,5 & 0,1 & tr & 393 & 0,18 & 1,28 & 1,44 & 1,43 & & & 0,16 \\
\hline $\begin{array}{l}\text { Filé mignon sem gordura } \\
\text { cru }\end{array}$ & 2,9 & 1,9 & 0,2 & & 55 & 0,17 & 1,44 & 1,16 & 1,69 & 0,01 & & 0,10 \\
\hline Lagarto cru & 2,3 & 2,3 & 0,1 & & 56 & 0,14 & 1,36 & 0,66 & 1,98 & & & 0,08 \\
\hline Maminha crua & 3,1 & 3,1 & 0,1 & 0,01 & 51 & 0,21 & 1,71 & 0,93 & 2,70 & & & 0,08 \\
\hline $\begin{array}{l}\text { Miolo de alcatra sem } \\
\text { gordura crua }\end{array}$ & 3,4 & 3,3 & 0,1 & & 60 & 0,20 & 1,79 & 1,10 & 2,85 & 0,01 & & 0,16 \\
\hline Músculo sem gordura cru & 2,2 & 2,6 & 0,1 & & 51 & 0,12 & 1,27 & 0,71 & 2,35 & & & 0,08 \\
\hline Patinho sem gordura cru & 2,0 & 1,9 & 0,2 & & 56 & 0,11 & 1,08 & 0,66 & 1,65 & & & 0,07 \\
\hline $\begin{array}{l}\text { Picanha com gordura } \\
\text { crua }\end{array}$ & 6,1 & 6,7 & 0,3 & & $\begin{array}{l}\text { *análise em } \\
\text { reavaliação }\end{array}$ & 0,42 & 3,46 & 1,83 & 5,86 & & & 0,22 \\
\hline $\begin{array}{l}\text { Picanha sem gordura } \\
\text { crua }\end{array}$ & 2,0 & 2,1 & 0,1 & tr & 75 & 0,15 & 1,18 & 0,61 & 1,83 & & & 0,04 \\
\hline $\begin{array}{l}\text { Asa de frango com pele } \\
\text { crua }\end{array}$ & 4,4 & 6,6 & 3,0 & & 113 & 0,09 & 3,36 & 0,93 & 5,75 & & & 0,03 \\
\hline Coração de frango cru & 4,9 & 6,3 & 3,4 & & 159 & 0,12 & 3,49 & 1,16 & 5,56 & & & 0,09 \\
\hline $\begin{array}{l}\text { Coxa de frango com } \\
\text { pele crua }\end{array}$ & 3,0 & 4,1 & 2,2 & & 97 & 0,05 & 2,24 & 0,68 & 3,61 & & & 0,04 \\
\hline $\begin{array}{l}\text { Coxa de frango sem } \\
\text { pele crua }\end{array}$ & 1,6 & 2,1 & 0,8 & & 91 & 0,03 & 1,19 & 0,40 & 1,82 & & & 0,01 \\
\hline Fígado de frango cru & 1,3 & 0,7 & 0,6 & tr & 341 & 0,02 & 0,69 & 0,58 & 0,58 & & 0,02 & 0,01 \\
\hline $\begin{array}{l}\text { Peito de frango com } \\
\text { pele cru }\end{array}$ & 2,2 & 3,2 & 0,9 & & 80 & 0,06 & 1,66 & 0,46 & 2,75 & & & 0,03 \\
\hline $\begin{array}{l}\text { Peito de frango sem } \\
\text { pele cru }\end{array}$ & 1,1 & 1,3 & $\operatorname{tr}$ & & 59 & 0,03 & 0,79 & 0,25 & 1,16 & & & 0,01 \\
\hline $\begin{array}{l}\text { Sobrecoxa de frango com } \\
\text { pele crua }\end{array}$ & 6,5 & 9,6 & 3,6 & & 88 & 0,12 & 4,96 & 1,31 & 8,44 & & & 0,06 \\
\hline $\begin{array}{l}\text { Sobrecoxa de frango sem } \\
\text { pele crua }\end{array}$ & 3,0 & 4,5 & 1,6 & & 84 & 0,06 & 2,30 & 0,61 & 3,87 & & & 0,03 \\
\hline Lingüiça de frango crua & 5,2 & 7,3 & 3,5 & 0,01 & 64 & 0,16 & 3,59 & 1,35 & 6,70 & & & 0,04 \\
\hline Lingüiça de porco crua & 4,0 & 5,0 & 1,7 & 0,01 & 53 & 0,15 & 2,52 & 1,24 & 4,66 & & & 0,03 \\
\hline Peru congelado cru & 0,4 & 0,4 & 0,7 & 0,01 & 68 & 0,01 & 0,26 & 0,14 & 0,41 & & & \\
\hline Bisteca de porco crua & 3,5 & 3,9 & 1,2 & 0,01 & 56 & 0,13 & 2,17 & 1,12 & 3,37 & & & \\
\hline Costela de porco crua & 7,4 & 8,3 & 2,3 & 0,02 & 69 & 0,28 & 4,59 & 2,42 & 7,64 & & & \\
\hline Lombo de porco crua & 3,3 & 3,7 & 1,0 & 0,01 & 55 & 0,12 & 2,08 & 1,00 & 3,39 & & & \\
\hline Pernil de porco cru & 4,2 & 5,0 & 1,7 & 0,01 & 59 & 0,16 & 2,58 & 1,29 & 4,64 & & & \\
\hline Toucinho cru & 17,7 & 20,1 & 10,1 & 0,06 & 73 & 0,75 & 11,42 & 5,21 & 18,82 & & & 0,21 \\
\hline \multicolumn{13}{|l|}{ Leite e derivados } \\
\hline logurte natural & 1,8 & 0,9 & 0,1 & 0,07 & 14 & 0,30 & 0,91 & 0,40 & 0,83 & & tr & \\
\hline logurte natural desnatado & 0,2 & 0,1 & & 0,01 & 3 & 0,03 & 0,10 & 0,05 & 0,09 & & & 0,01 \\
\hline $\begin{array}{l}\text { Leite de vaca desnatado } \\
\text { em pó }\end{array}$ & 0,6 & 0,2 & $\operatorname{tr}$ & 0,02 & 25 & 0,09 & 0,29 & 0,12 & 0,20 & & & 0,02 \\
\hline Leite de vaca integral & 1,4 & 0,7 & 0,1 & 0,06 & 10 & 0,25 & 0,71 & 0,29 & 0,65 & & $\operatorname{tr}$ & \\
\hline
\end{tabular}


Diretrizes

\begin{tabular}{|c|c|c|c|c|c|c|c|c|c|c|c|c|}
\hline Alimento & $\begin{array}{l}\text { AGS } \\
\text { (g) }\end{array}$ & $\begin{array}{l}\text { AGM } \\
\text { (g) }\end{array}$ & $\begin{array}{l}\text { AGP } \\
(\mathrm{g})\end{array}$ & $\begin{array}{l}\text { Láurico } \\
\text { 12:0(g) }\end{array}$ & $\begin{array}{l}\text { Colesterol } \\
(\mathrm{mg})\end{array}$ & $\begin{array}{l}\text { Mirístico } \\
\text { 14:0(g) }\end{array}$ & $\begin{array}{l}\text { Palmístico } \\
\text { 16:0(g) }\end{array}$ & $\begin{array}{l}\text { Esteárico } \\
\text { 18:0(g) }\end{array}$ & $\begin{array}{l}\text { Oléico } \\
\text { 18:1(g) }\end{array}$ & $\begin{array}{c}\text { EPA } \\
20: 5(\mathrm{~g})\end{array}$ & $\begin{array}{c}\text { DHA } \\
22: 6(\mathrm{~g})\end{array}$ & $\begin{array}{l}\text { Elaídico } \\
18: 1 t(g)\end{array}$ \\
\hline $\begin{array}{l}\text { Leite de vaca integral } \\
\text { em pó }\end{array}$ & 16,3 & 7,1 & 0,5 & 0,58 & 85 & 2,62 & 8,11 & 3,48 & 6,25 & & & 0,84 \\
\hline Queijo minas frescal & 11,4 & 5,8 & 0,4 & 0,41 & 62 & 1,73 & 5,78 & 2,53 & 5,14 & & & 0,54 \\
\hline Queijo parmesão & 19,7 & 8,7 & 0,4 & 0,70 & 106 & 3,26 & 10,07 & 4,24 & 7,67 & & & 1,01 \\
\hline Requeijão cremoso & 13,7 & 6,4 & 0,3 & 0,52 & 74 & 2,26 & 7,16 & 2,72 & 5,54 & & & 0,55 \\
\hline Ricota & 4,5 & 2,4 & 0,2 & 0,15 & 49 & 0,66 & 2,28 & 1,06 & 2,16 & & & 0,21 \\
\hline \multicolumn{13}{|l|}{ Ovos e derivados } \\
\hline $\begin{array}{l}\text { Ovo de codorna inteiro } \\
\text { cru }\end{array}$ & 8,9 & 12,1 & 2,7 & $\operatorname{tr}$ & 305 & 0,13 & 6,39 & 2,31 & 11,01 & & & 0,04 \\
\hline $\begin{array}{l}\text { Gema cozida } \\
\text { (10 minutos) }\end{array}$ & 9,2 & 12,1 & 4,0 & & 1272 & 0,08 & 6,56 & 2,43 & 11,29 & & 0,10 & 0,05 \\
\hline $\begin{array}{l}\text { Ovo de galinha inteiro } \\
\text { cozido (10 minutos) }\end{array}$ & 2,9 & 3,8 & 1,1 & & 397 & 0,02 & 2,07 & 0,76 & 3,51 & & 0,02 & 0,02 \\
\hline Ovo de galinha inteiro cru & 2,6 & 3,6 & 1,2 & & 356 & 0,02 & 1,87 & 0,69 & 3,33 & & 0,04 & \\
\hline \multicolumn{13}{|l|}{ Produtos açucarados } \\
\hline Achocolatado em pó & 1,1 & 0,6 & 0,3 & tr & $\operatorname{tr}$ & 0,02 & 0,51 & 0,55 & 0,62 & & & 0,01 \\
\hline Chocolate ao leite & 17,5 & 10,0 & 0,9 & 0,09 & 17 & 0,34 & 7,46 & 9,12 & 9,75 & & & 0,17 \\
\hline $\begin{array}{l}\text { Chocolate ao leite } \\
\text { dietético }\end{array}$ & 19,2 & 11,4 & 1,5 & 0,06 & 13 & 0,22 & 8,08 & 10,29 & 11,32 & & & 0,18 \\
\hline Chocolate meio amargo & 13,1 & 8,1 & 1,0 & 0,01 & 2 & 0,06 & 5,61 & 7,08 & 8,03 & & & 0,14 \\
\hline Cocada branca & 8,4 & 0,4 & 0,1 & 4,56 & NA & 1,56 & 0,61 & 0,20 & 0,36 & & & \\
\hline \multicolumn{13}{|l|}{ Alimentos industrializados } \\
\hline $\begin{array}{l}\text { Azeitona preta em } \\
\text { conserva }\end{array}$ & 3,5 & 11,0 & 3,0 & & NA & & 2,87 & 0,47 & 10,57 & & & \\
\hline $\begin{array}{l}\text { Azeitona verde em } \\
\text { conserva }\end{array}$ & 2,3 & 8,3 & 1,0 & & NA & & 1,93 & 0,29 & 8,07 & & & \\
\hline $\begin{array}{l}\text { Chantilly spray com } \\
\text { gordura vegetal }\end{array}$ & 25,9 & 0,1 & 0,1 & 10,70 & $\operatorname{tr}$ & 3,64 & 2,63 & 7,46 & 0,05 & & & \\
\hline $\begin{array}{l}\text { Leite de coco } \\
\text { industrializado }\end{array}$ & 15,6 & 0,9 & 0,2 & 8,25 & NA & 2,99 & 1,33 & 0,51 & 0,92 & & & \\
\hline $\begin{array}{l}\text { Maionese industrializada } \\
\text { tradicional com ovos }\end{array}$ & 4,1 & 6,4 & 15,4 & & 42 & 0,02 & 2,84 & 0,37 & 6,24 & & & \\
\hline \multicolumn{13}{|l|}{ Alimentos preparados } \\
\hline Acarajé & 9,1 & 7,8 & 2,1 & 0,10 & 25 & 0,16 & 7,71 & 1,05 & 7,81 & & & \\
\hline Arroz carreteiro & 3,2 & 3,0 & 0,2 & & 36 & 0,19 & 1,61 & 1,29 & 2,64 & & & 0,18 \\
\hline Cuscuz paulista & 1,8 & 1,8 & 0,8 & 0,03 & 15 & 0,15 & 1,12 & 0,41 & 1,64 & & & 0,04 \\
\hline \multicolumn{13}{|l|}{ Nozes e sementes } \\
\hline $\begin{array}{l}\text { Castanha de caju torrada } \\
\text { com sal }\end{array}$ & 7,7 & 26,5 & 8,1 & & NA & & 3,95 & 3,42 & 26,27 & & & 0,11 \\
\hline Coco cru & 30,0 & 1,5 & 0,3 & 15,37 & NA & 6,12 & 2,74 & 0,97 & 1,47 & & & \\
\hline Gergelim, semente & 7,8 & 19,9 & 22,5 & & NA & 0,03 & 4,86 & 2,58 & 19,72 & & & \\
\hline Linhaça, semente & 4,2 & 7,1 & 25,3 & & NA & 0,03 & 2,49 & 1,62 & 7,06 & & & \\
\hline Noz crua & 5,6 & 8,7 & 44,1 & & NA & & 4,26 & 1,34 & 8,66 & & & \\
\hline
\end{tabular}




\section{Referências}

1. Organização Mundial da Saúde (OMS). Cardiovacular Diseases (CVDs). Fact Sheet no 317; 2011. [Citado em 2011 out 24].Disponível em: Disponível em http://www.who.int/mediacentre/factsheets/fs317/en/index.html.

2. Ministério da Saúde. DATASUS. Indicadores e dados básicos - Brasil-2009. [Citado em 2011 out 24]. Disponível em: http://tabnet.datasus.gov.br/cgi/ tabcgi.exe?idb2009/c04.def

3. Sociedade Brasileira de Cardiologia / Sociedade Brasileira de Hipertensão / Sociedade Brasileira de Nefrologia. VI Diretrizes brasileiras de hipertensão. Arq Bras Cardiol. 2010;95(1 supl.1):1-51.

4. Sposito AC, Caramelli B, Fonseca FA, Bertolami MC, Afiune Neto A, Souza AD, et al. / Sociedade Brasileira de Cardiologia. IV Diretriz brasileira sobre dislipidemias e prevenção da aterosclerose. Departamento de Aterosclerose da Sociedade Brasileira de Cardiologia. Arq Bras Cardiol. 2007;88(supl 1):2-19.

5. Chapman MJ, Ginsberg HN, Amarenco P, Andreotti F, Borén J, Catapano AL, et al.; European Atherosclerosis Society Consensus Panel. Triglyceride-rich lipoproteins and high-density lipoprotein cholesterol in patients at high risk of cardiovascular disease: evidence and guidance for management. Eur Heart J. 2011;32(11):1345-61.

6. Coutinho JG, Gentil PC, Toral N. A desnutrição e obesidade no Brasil: o enfrentamento com base na agenda única da nutrição. Cad Saude Publica. 2008;24(supl 2):S332-40.

7. Instituto Brasileiro de Geografia e Estatística (IBGE). Diretoria de Pesquisas, Coordenação de Trabalho e Rendimento. Pesquisa de Orçamentos Familiares 2008-2009. [Acesso em 2011 out 29]. Disponível em http://www. ibge.gov.br/home/xml/pof_2008_2009.shtm.

8. Ministério da Saúde. Guia alimentar para a população Brasileira. Promovendo a alimentação saudável. 2006. [Acesso em 2011 out 29]. Disponível em http://nutricao.saude.gov.br/guia_conheca.php.

9. de Salvo VL, Gimeno SG. Reprodutibilidade e validade do questionário de freqüência de consumo de alimentos. Rev Saude Publica. 2002;36(4):505-12.

10. Ribeiro $A B$, Cardoso MA. Construção de um questionário de freqüência alimentar com subsídio para programas de prevenção de doenças crônicas não transmissíveis. Rev Nutr. 2002;15(2):239-45

11. Slater B, Philippi ST, Marchioni DM, Fisberg RM. Validação de questionários de freqüência alimentar - QFA: considerações metodológicas. Rev Bras Epidemiol. 2003;6(3):200-8.

12. Connor SL, Gustafson JR, Artaud-Wild SM, Flavell DP, Classick-Kohn CJ, Hatcher LF, et al. The cholesterol/saturated-fat index: an indication of the hypercholesterolaemic and atherogenic potential of food. Lancet. 1986;1(8492):1229-1232.

13. Keys A, Kimura N, Kusukawa A, Bonte-Stewart B, Larsen N, Keys MH. Lessons from serum cholesterol studies in Japan, Hawaii and Los Angeles. Ann Intern Med. 1958;48(1):83-94.

14. Keys A. Seven Countries: a multivariate analysis of atherosclerosis and coronary heart disease. Cambridge, MA: Harvard University Press; 1980.

15. Lands B. A critique of paradoxes in current advice on dietary lipids. Prog Lipid Res. 2008;47(2):77-106

16. Daumerie CM, Woollett LA, Dietschy JM. Fatty acids regulate hepatic low density lipoprotein receptor activity through redistribution of intracellular cholesterol pools. Proc Natl Acad Sci USA. 1992;89(22):10797-801

17. Lee JY, Carr TP. Dietary fatty acids regulate acyl-CoA: cholesterol acyltransferase and cytosolic cholesteryl ester hydrolase in hamsters. J Nutr. 2004;134(12):3239-44

18. Spritz N, Mishkel MA. Effects of dietary fats on plasma lipids and lipoproteins: and hypothesis for the lipid-lowering effect of unsaturated fatty acids. J Clin Invest. 1969;48(1):78-86.

19. Hegsted DM, McGandy RB, Myers ML, Stare FJ. Quantitative effects of dietary fat on serum cholesterol in man. Am J Clin Nutr. 1965;17(5):281-95.
20. Kris-Etherton PM, Yu S. Individual fatty acid effects on plasma lipids and lipoproteins: human studies. Am J Clin Nutr. 1997;65(5 Suppl):1628S-1644S.

21. Holman RT. How essential are fatty acids? JAMA. 1961;178:930-3.

22. Harris WS, Mozaffarian D, Rimm E, Kris-Etherton P, Rudel LL, Appel LJ, et al. Omega- 6 fatty acids and risk for cardiovascular disease: a science advisory from the American Heart Association Nutrition Subcommittee of the Council on Nutrition, Physical Activity, and Metabolism; Council on Cardiovascular Nursing; and Council on Epidemiology and Prevention. Circulation. 2009;119(6):902-7.

23. Moshfegh A, Goldman J, Cleveland L. What we eat in America: NHANES 2001-2002: Usual Nutrient Intakes from Food Compared to Dietary Reference Intakes. Beltsville, MD: US Department of Agriculture, Agricultural Research Service; 2005.

24. Sommerfeld M. Trans unsaturated fatty acids in natural products and processed foods. Prog Lipid Res. 1983;22(3):221-33.

25. Keys A, Anderson JT, Grande F. Serum cholesterol response to changes in the diet. II. The effect of cholesterol in the diet. Metabolism. 1965;14(7):759-65.

26. Beveridge JM, Connell WF, Mayer GA, Haust HL. The response of man to dietary cholesterol. J Nutr. 1960;71:61-5.

27. Connor WE, Hodges RE, Bleiler RE. Effect of dietary cholesterol upon serum lipids in man. J Lab Clin Med. 1961;57:331-942.

28. Connor WE, Hodges RE, Bleiler RE. The serum lipids in men receiving high cholesterol and cholesterol-free diets. J Clin Invest. 1961;40:894-901.

29. Steiner A, Howard EJ, Kgun S. Importance of dietary cholesterol in man. JAMA. 1962;181:186-90.

30. Grande F, Anderson JT, Chlouverakis C. Proja M, Keys A. Effect of dietary cholesterol on man's serum lipids. J Nutr. 1965;87(1):52-62.

31. Mattson FH, Erickson BA, Kligman AM. Effect of dietary cholesterol on serum cholesterol in man. Am J Clin Nutr. 1972;25(6):589-94.

32. National Diet-Heart Study. Research Group. National Diet-Heart Study Final Report. Update. Circulation. 1968;37(Suppl 1):II1428.

33. Billett MA, Bruce JS, White DA, Bennett AJ, Salter AM. Interactive effects of dietary cholesterol and different saturated fatty acids on lipoprotein metabolism in the hamster. Br J Nutr. 2000;84(4):439-47.

34. Tso TK, Park S, Tsai YH, Williams G, Snook JT. Effect of apolipoprotein E polymorphism on serum lipoprotein response to saturated fatty acids. Lipids. 1998;33(2):139-48.

35. Sarkkinen E, Korhonen M, Erkkila A, Ebeling T, Uusitupa M. Effect of apolipoprotein E polymorphism on serum lipid response to the separate modification of dietary fat and dietary cholesterol. Am J Clin Nutr. 1998;68(6):1215-22.

36. Clarke R, Frost C, Collins R, Appleby P, Peto R. Dietary lipids and blood cholesterol: quantitative meta-analysis of metabolic ward studies. BMJ. 1997;314(7074):112-7.

37. Howell WH, McNmara DJ, Tosca MA, Smith BT, Gaines JA. Plasma lipid and lipoprotein responses to dietary fat and cholesterol: a meta-analysis. Am J Clin Nutr. 1997;65(6):1747-64.

38. McGill HC. The relationship of dietary cholesterol to serum cholesterol concentration and to atherosclerosis in man. Am J Clin Nutr. 1979;32(12 Suppl):2664-702.

39. Hopkins PN, Heiss G, Ellison RC, Province MA, Pankow JS, Eckfeldt JH, et al. Coronary artery disease risk in familial combined hyperlipidemia and familial hypertriglyceridemia: a case-control comparison from the National Heart, Lung and Blood Institute Family Heart Study. Circulation. 2003;108(5):519-23.

40. Miettinen TA, Gylling H, Vanhanen H. Serum cholesterol response to dietary cholesterol and apoprotein E phenotype. Lancet. 1988;2(8622):1261.

41. Campos H, D`Agostino M, Ordovás JM. Gene-diet interactions and plasma lipoproteins: role of apolipoprotein $\mathrm{E}$ and habitual saturated fat intake. Genet Epidemiol. 2001;20(1):117-28. 
42. Agren JJ, Hallikainen M, Vidgren H, Miettinen TA, Gylling H. Postprandial lipemic response and lipoprotein composition in subjects with low or high cholesterol absorption efficiency. Clin Chim Acta. 2006;366(1-2):309-15.

43. Food and Nutrition Information Center. DRI. Report-Energy, Carbohydrate, Fiber, Fat, Fatty Acids, Cholesterol, Protein, and Amino Acids (Macronutrients). Baltimore: National Academy of Sciences. Institute of Medicine., Food and Nutrition Board; 2005.p.107-237, 769-879.

44. Expert Panel on Detection, Evaluation, and Treatment of High Blood Cholesterol in Adults. Executive Summary of The Third Report of The National Cholesterol Education Program (NCEP) Expert Panel on Detection, Evaluation, And Treatment of High Blood Cholesterol In Adults (Adult Treatment Panel III). JAMA. 2001;285(19):2486-97.

45. American Heart Association. AHA. Diagnosis and management of the metabolic syndrome. Circulation.2005;12:2735-52.

46. McNamara DJ. The impact of egg limitations on coronary heart disease risk: do the numbers add up? J Am Coll Nutr. 2000;19(5 Suppl):540S-548S

47. Hu FB, Stampfer MJ, Manson JE, Ascherio A, Colditz GA, Speizer FE, et al. Dietary saturated fat and their food sources in relation to the risk of coronary heart disease in women. Am J Clin Nutr. 1999;70:1001-8.

48. Hopkins PN. Effects of dietary cholesterol on serum cholesterol: a metaanalysis and review. Am J Clin Nutr. 1992;55(6):1060-70.

49. Djoussé L, Gaziano JM. Egg consumption in relation to cardiovascular disease and mortality: the Physician's Health Study. Am J Clin Nutr. 2008;87(4):964-9.

50. Zelman K. The great fat debate: a closer look at the controversyquestioning the validity of age-old dietary guidance. J Am Diet Assoc. 2011;111(5):655-8

51. Keys A. Effects of different dietary fats on plasma-lipid levels. Lancet. 1965;1(7380):318-9.

52. Mensink RP, Katan MB. Effect of dietary fatty acids on serum lipids and lipoproteins: a meta-analysis of 27 trials. Arterioscler Thromb. 1992;12(8):911-9.

53. Mensink RP, Zock PL, Kester AD, Katan MB. Effects of dietary fatty acids and carbohydrates on the ratio of serum total to HDL cholesterol and on serum lipids and apolipoproteins: a meta-analysis of 60 controlled trials. Am J Clin Nutr. 2003;77(5):1146-55.

54. Van Horn L, McCoin M, Kris-Etherton PM, Burke F, Carson JA, Champagne $\mathrm{CM}$, et al. The evidence for dietary prevention and treatment of cardiovascular disease. J Am Diet Assoc. 2008;108(2):287-331.

55. Micha R, Mozaffarian D. Saturated fat and cardiometabolic risk factors, coronary heart disease, stroke, and diabetes: a fresh look at the evidence. Lipids. 2010:45(10):893-905.

56. Sri-Tarino PW, Sun Q, Hu FB, Krauss RM. Saturated fat, carbohydrate, and cardiovascular disease. Am J Clin Nutr. 2010;91(3):502-9.

57. Howard BV, Van Horn L, Hsia J, Manson JE, Stefanick ML, WassertheilSmoller S, et al. Low-fat dietary pattern and risk of cardiovascular disease: the Women's Health Initiative Randomized Controlled Dietary Modification Trial. JAMA. 2006;295(6):655-66

58. Prentice RL, Caan B, Chlebowski RT, Patterson R, Kuller LH, Ockene JK, et al. Low-fat dietary pattern and risk of invasive breast cancer: the Women's Health Initiative Randomized Controlled Dietary Modification Trial. JAMA. 2006;295(6):629-42.

59. Jakobsen MU, O'Reilly EJ, Heitmann BL, Pereira MA, Bälter K, Fraser GE, et al. Major types of dietary fat and risk of coronary heart disease: a pooled analysis of 11 cohort studies. Am J Clin Nutr. 2009;89(5):1425-32.

60. Food and Agriculture Organization, World Health Organization. Ann Nutr Metab. 2009;91:502-9.

61. Mozaffarian D, Micha R, Wallace S. Effects on coronary heart disease of increasing polyunsaturated fat in place of saturated fat: a systematic review and meta-analysis of randomized controlled trials. Plos Med. 2010;7(3):e1000252.
62. Turpeinen O, Karvonen MJ, Pekkarinen M, Miettinen M, Elosuo R, Paavilainen E. Dietary prevention of coronary heart disease: the Finnish Mental Hospital Study. Int J Epidemiol. 1979;8(2):99-118.

63. Leren P. The Oslo diet-heart study: eleven-year report. Circulation 1970;42(5):935-42.

64. German JB, Gibson RA, Krauss RM, Nestel P, Lamarche B, van Staveren WA et al. A reappraisal of the impact of dairy foods and milk fat on cardiovascular disease risk. Eur J Nutr. 2009;48(4):191-203.

65. Smit LA, Baylin A, Campos H. Conjugated linoleic acid in adipose tissue and risk of myocardial infarction. Am J ClinNutr. 2010;92(1):34-40.

66. Shai I, Schwarzfuchs D, Henkin Y, Shahar DR, Witkow S, Greenberg I, et al Weight loss with a low-carbohydrate, Mediterranean, or low-fat diet. N Engl Med. 2008; 359(3):229-41.

67. Ascherio A, Rimm EB, Giovannucci EL, Colditz GA, Rosner B, Willett WC, et al. A prospective study of nutritional factors and hypertension among US men. Circulation. 1992;86(5):1475-84

68. Stamler J, Caggiula A, Grandits GA, Kjelsberg M, Cutler JA. Relationship to blood pressure of combinations of dietary macronutrients. Findings of the Multiple Risk Factor Intervention Trial (MRFIT). Circulation. 1996;94(10):2417-23.

69. Sudheendran S, Chang CC, Deckelbaum RJ. N-3 vs. saturated fatty acids effects on the arterial wall. Prostaglandins Leukot Essent Fatty Acids. 2010;82(4-6):205-9.

70. Yamagishi K, Iso H, Yatsuya H, Tanabe N, Date C, Kikuchi S, et al. Dietary intake of saturated fatty acids and mortality from cardiovascular disease in Japanese: the Japan Collaborative Cohort Study for Evaluation of Cancer Risk (JACC) Study. Am J Clin Nutr. 2010;92(4):759-65.

71. Mozaffarian D, Rimm EB, Herrington DM. Dietary fats, carbohydrate, and progression of coronary atherosclerosis in postmenopausal women. Am J Clin Nutr. 2004;80(5):1175-84.

72. de Roos N, Schouten E, Katan M. Consumption of a solid fat rich in lauric acid results in a more favorable serum lipid profile in healthy men and women than consumption of a solid fat rich in trans-fatty acids. J Nutr. $2001 ; 131(2): 242-5$

73. Lipoeto NI, Agus Z, Oenzil F, Wahlqvist M, Wattanapenpaiboon N Dietary intake and the risk of coronary heart disease among the coconutconsuming Minangkabau in West Sumatra, Indonesia. Asia Pac J Clin Nutr. 2004:13(4):377-84

74. Kumar PD. The role of coconut and coconut oil in coronary heart disease in Kerala, south India. Trop Doct. 1997;27(4):215-7.

75. Assunção ML, Ferreira HS, dos Santos AF, Cabral CR Jr, Florêncio TM. Effects of dietary coconut oil on the biochemical and anthropometric profiles of women presenting abdominal obesity. Lipids. 2009;44(7):593-601.

76. Lecker JL, Matthan NR, Billheimer JT, Rader DJ, Lichtenstein AH. Impact of dietary fat type within the context of altered cholesterol homeostasis on cholesterol and lipoprotein metabolism in the F1B hamster. Metabolism. 2010;59(10):1491-501.

77. Edem DO. Palm oil: biochemical, physiological, nutritional, hematological and toxicological aspects: a review. Plant Foods Hum Nutr. 2002;57(3 4):319-41

78. Vega-Lopez S, Ausman LM, Jalbert SM, Erkkila AT, Lichtenstein AH. Palm and partially hydrogenated soybean oils adversely alter lipoprotein profiles compared with soybean and canola oils in moderately hyperlipidemic subjects. Am J Clin Nutr. 2006;84(1):54-62.

79. Mattson FH, Grundy SM. Comparison of effects of dietary saturated monounsaturated, and polyunsaturated fatty acids on plasma lipids and lipoproteins in man. J Lipid Res. 1985;26(2):194-202.

80. Rudel LL, Haines JL, Sawyer JK. Effects on plasma lipoproteins o monounsaturated, saturated, and polyunsaturated fatty acids in the diet of African green monkeys. J Lipid Res. 1990;31(10):1873-82. 
81. Denke MA, Grundy SM. Comparison of effects of lauric acid and palmitic acid on plasma lipids and lipoproteins. Am J Clin Nutr. 1992;56(5):895-8.

82. Zock PL, de Vries JH, Katan MB. Impact of myristic acid versus palmitic acid on serum lipid and lipoprotein levels in healthy women and men. Arterioscler Thromb. 1994;14(4):567-75.

83. Cuesta C, Rodenas S, Merinero MC, Rodriguez-Gil S, Sanchez-Muniz FJ. Lipoprotein profiles and serum peroxide levels of aged women consuming palmolein or oleic acid-rich sunflower oil diets. Eur J Clin Nutr. 1998;52(9):675-83.

84. Rudel LL, Parks JS, Sawyer JK. Compared with dietary monounsaturated and saturated fat, polyunsaturated fat protects African green monkeys from coronary artery atherosclerosis. Arterioscler Thromb Vasc Biol. 1995;15(12):2101-10.

85. Ministério da Saúde. Agência Nacional de Vigilância Sanitária.(ANVISA). Legislação. VisaLegis. Resolução RDC n.264, de 22 de setembro de 2005: aprova regulamento técnico para fixação de identidade e qualidade de chocolate e chocolate branco.[Citado em 2010 nov 10]. Disponível em: http://e-legis.anvisa.gov.br/leisref/public/showAct. ph?id=18823\&word $=$ chocolate

86. Wang JF, Schramm DD, Holt RR, Ensunsa JL, Fraga CC, Schmitz HH, et al. A dose-response effect from chocolate consumption on plasma epicatechin and oxidative damage. J Nutr. 2000;130(8S Suppl):2115S-9S.

87. Ministério da Agricultura, do Abastecimento e da Reforma Agrária. Gabinete do Ministro. Regulamento técnico de identidade e qualidade de manteiga. Portaria n. 146 de 07 de março de 1996. [Citado em 2010 jan 08].Disponível em: http://www.agais.com/normas/leite/manteiga.htm

88. Richards NSPS. Desenvolvimento e caracterização de manteigas aromatizadas [Tese]. São Paulo; Faculdade de Ciências Farmacêuticas. Universidade de São Paulo;2001.

89. Judd JT, Baer DJ, Clevidence BA, Muesing RA, Chen SC, Westrate JA, et al. Effects of margarine compared with those of butter on blood lipid profiles related to cardiovascular disease risk factors in normolipemic adults fed controlled diets. Am J Clin Nutr. 1998;68(4):768-77.

90. Han SN, Leka LS, Lichtenstein AH, Ausman LM, Schaefer EJ, Meydani $\mathrm{SN}$. Effect of hydrogenated and saturated, relative to polyunsaturated, fat on immune and inflammatory responses of adults with moderate hypercholesterolemia. J Lipid Res. 2002;43(3):445-52.

91. Gagliardi AC; Maranhão RC, de Souza HP, Schaefer El, Santos RD. Effects of margarines and butter consumption on lipid profiles, inflammation markers and lipid transfer to HDL particles in free-living subjects with the metabolic syndrome. Eur J Clin Nutr. 2010;64(10):1141-9.

92. Salles-Filho S, Zackiewics M. Prioridade de pesquisa para suínos e aves. Revista TeC Carnes. 2001;3(1):1-6.

93. Rocha YR, Aguiar JPL, Marinho HA, Shrimpton R. Aspectos nutritivos de alguns peixes da Amazônia. Acta Amazonica. 1982;12(4):787-94.

94. Ministério do Desenvolvimento, Indústria e Comércio Exterior. Instituto Nacional de Metrologia, Qualidade e Tecnologia.(INMETRO).Aves - Teor de gordura e colesterol em alimentos - 3 o Parte. Informações ao consumidor. Carnes bovina e suína - Teor de gordura e colesterol em alimentos. Brasilia;2001.

95. Ministério do Desenvolvimento, Indústria e Comércio Exterior. Instituto Nacional de Metrologia, Qualidade e Tecnologia.(INMETRO).Miúdos, vísceras e peixes - Teor de gordura e colesterol em alimentos - 20 Parte. Brasilia;2001.

96. de Lorgeril M, Salen P, Martin JL, Monjaud I, Delaye J, Mamelle N. Mediterranean diet, traditional risk factors, and the rate of cardiovascular complications after myocardial infarction: final report of the Lyon Diet Heart Study. Circulation. 1999;99(6):779-85.

97. De Biase SG, Fernandes SF, Gianini RJ, Duarte JL. Vegetarian diet and cholesterol and triglycerides levels. Arq Bras Cardiol. 2007;88(1):35-9.
98. Ministério do Desenvolvimento, Indústria e Comércio Exterior. Instituto Nacional de Metrologia, Qualidade e Tecnologia.(INMETRO). Programa de análise de produtos - analisa teor de gordura e de colesterol de queijos. [Citado em 2011 nov 10]. Disponível em: http://www.brasil.gov.br/noticias/ arquivos/2011/08/01/inmetro-analisa-teor-de-gordura-e-de-colesterol

99. Universidade Estadual de Campinas.(UNICAMP). Núcleo de estudos e pesquisas em alimentação.NEPA. Tabela brasileira de composição de alimentos-TACO-Versão 2.Campinas;2006.

100. Kris-Etherton PM, Pearson TA, Wan Y, Hargrove RL, Moriarty K, Fishell V, et al. High-monounsaturated fatty acid diets lower both plasma cholesterol and triacylglycerol concentrations. Am J Clin Nutr. 1999;70(6):1009-15.

101. Grundy SM. Comparison of monounsaturated fatty acids and carbohydrates for lowering plasma cholesterol. N Engl J Med. 1986;314(12):745-8.

102. Mensink RP, Katan MB. Effect of monounsaturated fatty acids versus complex carbohydrates on high-density lipoproteins in healthy men and women. Lancet. 1987;1(8525):122-5.

103. Kastorine CM, Milionis HJ, Esposito K, Giuliano D, Goudevenos JA, Panagiotakos DB. The effect of Mediterranean diet on metabolic syndrome and its components: a meta-analysis of 50 studies and 534,906 individuals. J Am Coll Cardiol. 2011;57(11):1299-313.

104. Reaven PD, Grasse BJ, Tribble DL. Effects of linoleate-enriched and oleateenriched diets in combination with alpha-tocopherol on the susceptibility of LDL and LDL subfractions to oxidative modification in humans. Arterioscler Thromb. 1994;14(4):557-66.

105. Reaven P, Parthasarathy S, Grasse BJ, Miller E, Almazan F, Mattson FH, et al. Feasibility of using an oleate-rich diet to reduce the susceptibility of lowdensity lipoprotein to oxidative modification in humans. Am J Clin Nutr. 1991;54(4):701-6

106. Astrup A. Weight loss with a low-carbohydrate, Mediterranean, or low-fat diet. N Engl J Med. 2008;359(20):2169-70.

107. Lopez S, Bermudez B, Ortega A, Varela LM, Pacheco YM, Villar J, et al. Effects of meals rich in either monounsaturated or saturated fat on lipid concentrations and on insulin secretion and action in subjects with high fasting triglyceride concentrations. Am J Clin Nutr. 2011;93(3):494-9.

108. Paniagua JA, de La Sacristana AG, Sánchez E, Romero I, Vidal-Puig A, Berral FJ, et al. A MUFA-rich diet improves posprandial glucose, lipid and GLP-1 responses in insulin-resistant subjects. J Am Coll Nutr. 2007;26(5):434-44.

109. Xiao C, Giacca A, Carpentier A, Lewis GF. Differential effects of monounsaturated, polyunsaturated and saturated fat ingestion on glucosestimulated insulin secretion, sensitivity and clearance in overweight and obese, non-diabetic humans. Diabetologia. 2006;49(6):1371-9.

110.Jiang R, Manson JE, Stampfer MJ, Liu S, Willett WC, Hu FB. Nut and peanut butter consumption and risk of type 2 diabetes in women. JAMA. 2002;288(20):2554-60.

111. Risérus $U$, WillettWC, Hu FB. Dietary fats and prevention of type 2 diabetes. Prog Lipid Res. 2009;48(1):44-51.

112. Vessby B, Uusitupa M, Hermansen K, Riccardi G, Rivellese AA, Tapsell LC, et al.; KANWU Study. Substituting dietary saturated for monounsaturated fat impairs insulin sensitivity in healthy men and women: The KANWU Study. Diabetologia. 2001;44(3):312-9.

113. Pérez-Jiménez F, López-Miranda J, Pinillos MD, Gómez P, Paz-Rojas E, Montilla $\mathrm{P}$, et al. A Mediterranean and a high-carbohydrate diet improve glucose metabolism in healthy young persons. Diabetologia. 2001;44(11):2038-43.

114. Paniagua JA, Gallego de la Sacristana A, Romero I, Vidal-PuigA, LatreJM, Sanchez E, et al. Monounsaturated fat-rich diet prevents central body fat distribution and decreases postprandial adiponectin expression induced by a carbohydrate-rich diet in insulin-resistant subjects. Diabetes Care. 2007;30(7):1717-23.

115. Louheranta AM, Sarkkinen ES, Vidgren HM, Schwab US, Uusitupa MI. Association of the fatty acid profile of serum lipids with glucose and insulin metabolism during 2 fat-modified diets in subjects with impaired glucose tolerance. Am J Clin Nutr. 2002;76(2):331-7. 
116. Brynes AE, Edwards CM, Jadhav A, Ghatei MA, Bloom SR, Frost GS. Dietinduced change in fatty acid composition of plasma triacylglycerols is not associated with change in glucagon-like peptide 1 or insulin sensitivity in people with type 2 diabetes. Am J Clin Nutr. 2000;72(5):1111-8.

117. Alonso A, Ruiz-Gutierrez V, Martinez-González MA. Monounsaturated fatty acids, olive oil and blood pressure: epidemiological, clinical and experimental evidence. Public Health Nutr. 2006;9(2):251-7.

118. Rasmussen BM, Vessby B, Uusitupa M, Berglund L, Pedersen E, Riccardi G, et al.; KANWU Study Group. Effects of dietary saturated, monounsaturated, and $\mathrm{n}-3$ fatty acids on blood pressure in healthy subjects. Am J Clin Nutr. 2006;83(2):221-6.

119. Witteman JC, Willett WC, Stampfer MJ, Colditz GA, Sacks FM, Speizer FE, et al. A prospective study of nutritional factors and hypertension among US women. Circulation. 1989;80(5):1320-7.

120. Ascherio A, Hennekens C, Willett WC, Sacks F, Rosner B, Manson J, et al. Prospective study of nutritional factors, blood pressure, and hypertension among US women. Hypertension. 1996;27(5):1065-72.

121. Stamler J, Liu K, Ruth KJ, Pryer J, Greenland P. Eight-year blood pressure change in middle-aged men: relationship to multiple nutrients. Hypertension. 2002;39(5):1000-6.

122. Williams PT, Fortmann SP, Terry RB, Garay SC, Vranizan KM, Ellsworth N, et al. Associations of dietary fat, regional adiposity, and blood pressure in men. JAMA. 1987;257(23):3251-6.

123. Trevisan M, Krogh V, Freudenheim J, Blake A, Muti P, Panico S, et al. Consumption of olive oil, butter, and vegetable oils and coronary heart disease risk factors. The Research Group ATS-RF2 of the Italian National Research Council. JAMA. 1990;263(5):688-92.

124. Psaltopoulou T, Naska A, Orfanos P, Trichopoulos D, Mountokalakis T, Trichopoulou A. Olive oil, the Mediterranean diet, and arterial blood pressure: the Greek European Prospective Investigation into Cancer and Nutrition (EPIC) study. Am J Clin Nutr. 2004;80(4):1012-8.

125. Alonso A, Martinez-González MA. Olive oil consumption and reduced incidence of hypertension: the SUN study. Lipids. 2004;39(12):1233-8.

126. Appel LJ, Sacks FM, Carey VJ, Obarzanek E, Swain JF, Miller ER 3rd, et al.; OmniHeart Collaborative Research Group. Effects of protein, monounsaturated fat, and carbohydrate intake on blood pressure and serum lipids: results of the OmniHeart randomized trial. JAMA. 2005;294(19):2455-64.

127. López-Miranda J, Badimon L, Bonanome A, Lairon D, Kris-Etherton PM, Mata P, et al. Monounsaturated fat and cardiovascular risk. Nutr Rev. 2006;10(Suppl 4):S2-12.

128. Perez-Jimenez F, Alvarez de Cienfuegos G, Badimon L, Barja G, Battino M, Blanco A, et al. International conference on the healthy effect of virgin olive oil. Eur J Clin Invest. 2005;35(7):421-4.

129. Delgado-Lista J, Garcia-Rios A, Perez-Martinez P, Lopez-Miranda J, PerezJimenez F. Olive oil and haemostasis: platelet function, thrombogenesis and fibrinolysis. Curr Pharm Des. 2011;17(8):778-85.

130. Keys A. Coronary heart disease in seven countries. Circulation. 1970;41(4 suppl):1-198.

131. Artaud-Wild SM, Connor SL, Sexton G, Connor WE. Differences in coronary mortality can be explained by differences in cholesterol and saturated fat intakes in 40 countries but not in France and Finland: a paradox. Circulation. 1993;88(6):2771-9

132. Pietinen P, Ascherio A, Korhonen P, Hartman AM, Willett WC, Albanes D, et al. Intake of fatty acids and risk of coronary heart disease in a cohort of Finnish men. The Alpha-Tocopherol, Beta-Carotene Cancer Prevention Study. Am J Epidemiol. 1997;145(10):876-87.

133. Mente A, de Koning L, Shannon HS, Anand SS. A systematic review of the evidence supporting a causal link between dietary factors and coronary heart disease. Arch Intern Med. 2009;169(7):659-69.
134. Balk EM, Lichtenstein AH, Chung M, Kupelnick B, Chew P, Lau J. Effects of omega-3 fatty acids on serum markers of cardiovascular disease risk: a systematic review. Atherosclerosis. 2006;189(1):19-30.

135. Harris WS. n-3 fatty acids and serum lipoproteins: human studies. Am J Clin Nutr. 1997;65(5 Suppl):1645S-1654S.

136. Hartweg J, Perera R, Montori V, Dinneen S, Neil HA, Farmer A. Omega-3 polyunsaturated fatty acids (PUFA) for type 2 diabetes mellitus. Cochrane Database Syst Rev. 2008;(1):CD003205.

137. Miller M, Stone NJ, Ballantyne C, Bittner V, Criqui MH, Ginsberg HN, et al.; American Heart Association Clinical Lipidology, Thrombosis, and Prevention Committee of the Council on Nutrition, Physical Activity, and Metabolism, Council on Arteriosclerosis, Thrombosis and Vascular Biology, Council on Cardiovascular N. Triglycerides and cardiovascular disease: a scientific statement from the American Heart Association. Circulation. 2011;123(20):2292-333.

138. Jacobson TA. Role of $n-3$ fatty acids in the treatment of hypertriglyceridemia and cardiovascular disease. Am J Clin Nutr. 2008;87(6):1981S-90S.

139. Meyer KA, Kushi LH, Jacobs DR Jr, Folsom AR. Dietary fat and incidence of type 2 diabetes in older lowa women. Diabetes Care. 2001;24(9):1528-35.

140. Kaushik M, Mozaffarian D, Spiegelman D, Manson JE, Willett WC, Hu FB. Long-chain omega-3 fatty acids, fish intake, and the risk of type 2 diabetes mellitus. Am J Clin Nutr. 2009;90(3):613-20.

141. Brostow DP, Odegaard AO, Koh WP, Duval S, Gross MD, Yuan JM, et al. Omega-3 fatty acids and incident type 2 diabetes: the Singapore Chinese Health Study. Am J Clin Nutr. 2011;94(2):520-6.

142. Djoussé L, Biggs ML, Lemaitre RN, King IB, Song X, Ix JH, et al. Plasma omega-3 fatty acids and incident diabetes in older adults. Am J Clin Nutr. 2011;94(2):527-33

143. Friedberg CE, Janssen MJ, Heine RJ, Grobbee DE. Fish oil and glycemic control in diabetes: a meta-analysis. Diabetes Care. 1998;21(4):494-500.

144. Geleijnse JM, Giltay EJ, Grobbee DE, Donders AR, Kok FJ. Blood pressure response to fish oil supplementation: metaregression analysis of randomized trials. J Hypertens. 2002;20(8):1493-9.

145. GrynbergA. Hypertension prevention: from nutrients to (fortified) foods to dietary patterns: focus on fatty acids. J Hum Hypertens. 2005;19(Suppl 3):S25-33 .

146. de Roos B, Mavrommatis Y, Brouwer IA. Long-chain n-3 polyunsaturated fatty acids: new insights into mechanisms relating to inflammation and coronary heart disease. Br J Pharmacol. 2009:158(2):413-28.

147. Saravanan P, Davidson NC, Schmidt EB, Calder PC. Cardiovascular effects of marine omega-3 fatty acids. Lancet. 2010;376(9740):540-50.

148. Lopez-Garcia E, Schulze MB, Manson JE, Meigs JB, Albert CM Rifai N, et al. Consumption of (n-3) fatty acids is related to plasma biomarkers of inflammation and endothelial activation in women. J Nutr. 2004;134(7):1806-11.

149. Niu K, Hozawa A, Kuriyama S, Ohmori-Matsuda K, Shimazu T, Nakaya N, et al. Dietary long-chain $\mathrm{n}-3$ fatty acids of marine origin and serum C-reactive protein concentrations are associated in a population with a diet rich in marine products. Am J Clin Nutr. 2006;84(1):223-9.

150. Micallef MA, Munro IA, Garg ML. An inverse relationship between plasma n-3 fatty acids and C-reactive protein in healthy individuals. Eur J Clin Nutr. 2009;63(9):1154-6.

151. Farzaneh-Far R, Harris WS, Garg S, Na B, Whooley MA. Inverse association of erythrocyte $n-3$ fatty acid levels with inflammatory biomarkers in patients with stable coronary artery disease: the Heart and Soul Study. Atherosclerosis. 2009;205(2):538-43.

152. Madsen T, Skou HA, Hansen VE, Fog L, Christensen JH, Toft E, et al. C-reactive protein, dietary n-3 fatty acids, and the extent of coronary artery disease. Am J Cardiol. 2001;88(10):1139-42.

153. Rizza S, Tesauro M, Cardillo C, Galli A, lantorno M, Gigli F, et al. Fish oil supplementation improves endothelial function in normoglycemic offspring of patients with type 2 diabetes. Atherosclerosis. 2009;206(2):569-74. 
154. Kelley DS, Siegel D, Fedor DM, Adkins Y, Mackey BE. DHA supplementation decreases serum C-reactive protein and other markers of inflammation in hypertriglyceridemic men. J Nutr. 2009;139(3):495-501.

155. Murphy KJ, Meyer BJ, Mori TA, Burke V, Mansour J, Patch CS, et al. Impact of foods enriched with n-3 long-chain polyunsaturated fatty acids on erythrocyte $\mathrm{n}-3$ levels and cardiovascular risk factors. Br J Nutr. 2007;97(4):749-57.

156. Petersson H, Risérus U, McMonagle J, Gulseth HL, Tierney AC, Morange S, et al. Effects of dietary fat modification on oxidative stress and inflammatory markers in the LIPGENE study. Br J Nutr. 2010;104(9):1357-62.

157. Madsen T, Christensen JH, Schmidt EB. C-reactive protein and n-3 fatty acids in patients with a previous myocardial infarction: a placebo-controlled randomized study. Eur J Nutr. 2007;46(7):428-30.

158. Madsen T, Christensen JH, Blom M, Schmidt EB. The effect of dietary n-3 fatty acids on serum concentrations of $C$-reactive protein: a dose-response study. Br J Nutr. 2003;89(4):517-22.

159. Egert S, Stehle P. Impact of $n-3$ fatty acids on endothelial function: results from human interventions studies. Curr Opin Clin Nutr Metab Care. 2011;14(2):121-31.

160. Wang HH, Hung TM, Wei J, Chiang AN. Fish oil increases antioxidant enzyme activities in macrophages and reduces atherosclerotic lesions in apoE-knockout mice. Cardiovasc Res. 2004;61(1):169-76.

161. Zampolli A, Bysted A, Leth T, Mortensen A, De Caterina R, Falk E. Contrasting effect of fish oil supplementation on the development of atherosclerosis in murine models. Atherosclerosis. 2006;184(1):78-85.

162. Saraswathi V, Gao L, Morrow JD, Chait A, Niswender KD, Hasty AH. Fish oil increases cholesterol storage in white adipose tissue with concomitant decreases in inflammation, hepatic steatosis, and atherosclerosis in mice. J Nutr. 2007;137(7):1776-82.

163. Casós K, Sáiz MP, Ruiz-Sanz JI, Mitjavila MT. Atherosclerosis prevention by a fish oil-rich diet in apoE(-/-) mice is associated with a reduction of endothelial adhesion molecules. Atherosclerosis. 2008;201(2):306-17.

164. Matsumoto M, Sata M, Fukuda D, Tanaka K, Soma M, Hirata Y, et al. Orally administered eicosapentaenoic acid reduces and stabilizes atherosclerotic lesions in ApoE-deficient mice. Atherosclerosis. 2008;197(2):524-33.

165. Xu Z, Riediger N, Innis S, Moghadasian MH. Fish oil significantly alters fatty acid profiles in various lipid fractions but not atherogenesis in apo E-KO mice. Eur J Nutr. 2007;46(2):103-10.

166. Sekikawa A, Curb JD, Ueshima H, El-Saed A, Kadowaki T, Abbott RD, et al.; ERA JUMP (Electron-Beam Tomography, Risk Factor Assessment Among Japanese and U.S. Men in the Post-World War II Birth Cohort) Study Group. Marine-derived n-3 fatty acids and atherosclerosis in Japanese, JapaneseAmerican, and white men: a cross-sectional study. J Am Coll Cardiol. 2008;52(6):417-24.

167. Heine-Bröring RC, Brouwer IA, Proença RV, van Rooij FJ, Hofman A, Oudkerk $\mathrm{M}$, et al. Intake of fish and marine $\mathrm{n}-3$ fatty acids in relation to coronary calcification: the Rotterdam Study. Am J Clin Nutr. 2010;91(5):1317-23.

168. He K, Liu K, Daviglus ML, Mayer-Davis E, Jenny NS, Jiang R, et al. Intakes of long-chain n-3 polyunsaturated fatty acids and fish in relation to measurements of subclinical atherosclerosis. Am J Clin Nutr. 2008;88(4):1111-8.

169. von Schacky C, Angerer P, Kothny W, Theisen K, Mudra H. The effect of dietary omega-3 fatty acids on coronary atherosclerosis: a randomized, double-blind, placebo-controlled trial. Ann Intern Med. 1999;130(7):554-62.

170.Angerer P, Kothny W, Störk S, von Schacky C. Effect of dietary supplementation with omega- 3 fatty acids on progression of atherosclerosis in carotid arteries. Cardiovasc Res. 2002;54(1):183-90.

171. Mita T, Watada H, Ogihara T, Nomiyama T, Ogawa O, Kinoshita J, et al. Eicosapentaenoic acid reduces the progression of carotid intimamedia thickness in patients with type 2 diabetes. Atherosclerosis. 2007;191(1):162-7.
172. Thies F, Garry JM, Yaqoob P, Rerkasem K, Williams J, Shearman CP, et al. Association of $n-3$ polyunsaturated fatty acids with stability of atherosclerotic plaques: a randomised controlled trial. Lancet. 2003;361(9356):477-85.

173. Burr ML, Fehily AM, Gilbert JF, Rogers S, Holliday RM, Sweetnam PM, et al. Effects of changes in fat, fish, and fibre intakes on death and myocardial reinfarction: diet and reinfarction trial (DART). Lancet. 1989;2(8666):757-61.

174. Dietary supplementation with $\mathrm{n}-3$ polyunsaturated fatty acids and vitamin E after myocardial infarction: results of the GISSI-Prevenzione trial. Gruppo Italiano per lo Studio della Sopravvivenza nell'Infarto miocardico. Lancet. 1999;354(9177):447-55.

175. Burr ML, Ashfield-Watt PA, Dunstan FD, Fehily AM, Breay P, Ashton T, et al. Lack of benefit of dietary advice to men with angina: results of a controlled trial. Eur J Clin Nutr. 2003;57(2):193-200.

176. Svensson M, Schmidt EB, Jørgensen KA, Christensen JH; OPACH Study Group. N-3 fatty acids as secondary prevention against cardiovascular events in patients who undergo chronic hemodialysis: a randomized, placebocontrolled intervention trial. Clin J Am Soc Nephrol. 2006;1(4):780-6.

177. Yokoyama M, Origasa H, Matsuzaki M, Matsuzawa Y, Saito Y, Ishikawa $Y$, et al.; Japan EPA lipid intervention study (JELIS) Investigators. Effects of eicosapentaenoic acid on major coronary events in hypercholesterolaemic patients (JELIS): a randomised open-label, blinded endpoint analysis. Lancet. 2007;369(9567):1090-8.

178. Gissi-HF Investigators, Tavazzi L, Maggioni AP, Marchioli R, Barlera S, Franzosi MG, Latini $R$, et al. Effect of $n-3$ polyunsaturated fatty acids in patients with chronic heart failure (the GISSI-HF trial): a randomised, double-blind, placebo-controlled trial. Lancet. 2008;372(9645):1223-30.

179. Kromhout D, Giltay EJ, Geleijnse JM; Alpha Omega Trial Group. n-3 fatty acids and cardiovascular events after myocardial infarction. N Engl J Med. 2010;363(21):2015-26.

180. Rauch B, Schiele R, Schneider S, Diller F, Victor N, Gohlke H, et al.; OMEGA Study Group. OMEGA, a randomized, placebo-controlled trial to test the effect of highly purified omega-3 fatty acids on top of modern guideline-adjusted therapy after myocardial infarction. Circulation. 2010;122(21):2152-9.

181. Galan P, Kesse-Guyot E, Czernichow S, Briancon S, Blacher J, Hercberg S; SU.FOL.OM3 Collaborative Group. Effects of B vitamins and omega 3 fatty acids on cardiovascular diseases: a randomised placebo controlled trial. BMJ. 2010;341:c6273.

182. Bucher HC, Hengstler P, Schindler C, Meier G. N-3 polyunsaturated fatty acids in coronary heart disease: a meta-analysis of randomized controlled trials. Am J Med. 2002;112(4):298-304.

183. Hooper L, Thompson RL, Harrison RA, Summerbell CD, Moore H, Worthington $\mathrm{HV}$, et al. Omega 3 fatty acids for prevention and treatment of cardiovascular disease. Cochrane Database Syst Rev. 2004;(4):CD003177.

184. He K, Song Y, Daviglus ML, Liu K, Van Horn L, Dyer AR, et al. Accumulated evidence on fish consumption and coronary heart disease mortality: a metaanalysis of cohort studies. Circulation. 2004;109(22):2705-11.

185. Wang C, Harris WS, Chung M, Lichtenstein AH, Balk EM, Kupelnick B, et al. n-3 Fatty acids from fish or fish-oil supplements, but not alpha-linolenic acid, benefit cardiovascular disease outcomes in primary- and secondaryprevention studies: a systematic review. Am J Clin Nutr. 2006;84(1):5-17.

186. Mozaffarian D, Rimm EB. Fish intake, contaminants, and human health: evaluating the risks and the benefits. JAMA. 2006;296(15):1885-99.

187. León H, Shibata MC, Sivakumaran S, Dorgan M, Chatterley T, Tsuyuki RT. Effect of fish oil on arrhythmias and mortality: systematic review. BMJ. 2008;337:a2931.

188. Marik PE, Varon J. Omega-3 dietary supplements and the risk of cardiovascular events: a systematic review. Clin Cardiol. 2009;32(7):365-72.

189. Marchioli R, Barzi F, Bomba E, Chieffo C, Di Gregorio D, Di Mascio R, et al.; GISSI-Prevenzione Investigators. Early protection against sudden death by n-3 polyunsaturated fatty acids after myocardial infarction: time-course analysis of the results of the Gruppo Italiano per lo Studio della Soprawivenza nell'Infarto Miocardico (GISSI)-Prevenzione. Circulation. 2002;105(16):1897-903. 
190. Leaf A, Albert CM, Josephson M, Steinhaus D, Kluger J, Kang JX, et al.; Fatty Acid Antiarrhythmia Trial Investigators. Prevention of fatal arrhythmias in high-risk subjects by fish oil n-3 fatty acid intake. Circulation. 2005;112(18):2762-8

191. Raitt MH, Connor WE, Morris C, Kron J, Halperin B, Chugh SS, et al. Fish oil supplementation and risk of ventricular tachycardia and ventricular fibrillation in patients with implantable defibrillators: a randomized controlled trial. JAMA. 2005;293(23):2884-91.

192. Mozaffarian D, Bryson CL, Lemaitre RN, Burke GL, Siscovick DS. Fish intake and risk of incident heart failure. J Am Coll Cardiol. 2005;45(12):2015-21.

193. Yamagishi K, Iso H, Date C, Fukui M, Wakai K, Kikuchi S, et al.; Japan Collaborative Cohort Study for Evaluation of Cancer Risk Study Group. Fish, omega-3 polyunsaturated fatty acids, and mortality from cardiovascular diseases in a nationwide community-based cohort of Japanese men and women the JACC (Japan Collaborative Cohort Study for Evaluation of Cancer Risk) Study. J Am Coll Cardiol. 2008;52(12):988-96

194. Watson PD, Joy PS, Nkonde C, Hessen SE, Karalis DG. Comparison of bleeding complications with omega-3 fatty acids + aspirin + clopidogrel-versus--aspirin + clopidogrel in patients with cardiovascular disease. Am J Cardiol. 2009:104(8):1052-4.

195. Eritsland J, Arnesen H, Seljeflot I, Kierulf P. Long-term effects of n-3 polyunsaturated fatty acids on haemostatic variables and bleeding episodes in patients with coronary artery disease. Blood Coagul Fibrinolysis. 1995;6(1):17-22.

196. Wendland E, Farmer A, Glasziou P, Neil A. Effect of alpha linolenic acid on cardiovascular risk markers: a systematic review. Heart. 2006;92(2):166-9.

197. Prasad K. Flaxseed and cardiovascular health. J Cardiovasc Pharmacol. 2009; 54(5):369-77.

198. Bloedon LT, Balikai S, Chittams J, Cunnane SC, Berlin JA, Rader DJ, et al. Flaxseed and cardiovascular risk factors: results from a double blind, randomized, controlled clinical trial. J Am Coll Nutr. 2008;27(1):65-74.

199. Yoneyama S, Miura K, Sasaki S, Yoshita K, Morikawa Y, Ishizaki M, et al. Dietary intake of fatty acids and serum C-reactive protein in Japanese. J Epidemiol. 2007;17(3):86-92.

200. Poudel-Tandukar K, Nanri A, Matsushita Y, Sasaki S, Ohta M, Sato M, et al. Dietary intakes of alpha-linolenic and linoleic acids are inversely associated with serum C-reactive protein levels among Japanese men. Nutr Res. 2009;29(6):363-70.

201. Rallidis LS, Paschos G, Liakos GK, Velissaridou AH, Anastasiadis G, Zampelas A. Dietary alpha-linolenic acid decreases C-reactive protein, serum amyloid A and interleukin-6 in dyslipidaemic patients. Atherosclerosis. 2003;167(2):237-42.

202. Paschos GK, Rallidis LS, Liakos GK, Panagiotakos D, Anastasiadis G, Votteas $\mathrm{V}$, et al. Background diet influences the anti-inflammatory effect of alphalinolenic acid in dyslipidaemic subjects. Br J Nutr. 2004;92(4):649-55.

203. Mozaffarian D. Does alpha-linolenic acid intake reduce the risk of coronary heart disease? A review of the evidence. Altern Ther Health Med. 2005;11(3):24-30.

204. Mozaffarian D, Ascherio A, Hu FB, Stampfer MJ, Willett WC, Siscovick DS, et al. Interplay between different polyunsaturated fatty acids and risk of coronary heart disease in men. Circulation. 2005;111(2):157-64.

205. Albert CM, Oh K, Whang W, Manson JE, Chae CU, Stampfer MJ, etal. Dietary alpha-linolenic acid intake and risk of sudden cardiac death and coronary heart disease. Circulation. 2005;112(21):3232-8.

206. Brouwer IA, Katan MB, Zock PL. Dietary alpha-linolenic acid is associated with reduced risk of fatal coronary heart disease, but increased prostate cancer risk: a meta-analysis. J Nutr. 2004; 134(4):919-22.

207. Lichtenstein AH, Schwab US. Relationship of dietary fat to glucose metabolism. Atherosclerosis. 2000;150(2):227-43.
208. Salmerón J, Hu FB, Manson JE, Stampfer MJ, Colditz GA, Rimm EB, et al. Dietary fat intake and risk of type 2 diabetes in women. Am J Clin Nutr. 2001;73(6):1019-26

209. van Dam RM, Willett WC, Rimm EB, Stampfer MJ, Hu FB. Dietary fat and meat intake in relation to risk of type 2 diabetes in men. Diabetes Care. 2002;25(3):417-24.

210. Heine RJ, Mulder C, Popp-Snijders C, van der Meer J, van der Veen EA. Linoleic-acid-enriched diet: long-term effects on serum lipoprotein and apolipoprotein concentrations and insulin sensitivity in noninsulindependent diabetic patients. Am J Clin Nutr. 1989;49(3):448-56.

211. Summers LK, Fielding BA, Bradshaw HA, Ilic V, Beysen C, Clark ML, et al. Substituting dietary saturated fat with polyunsaturated fat changes abdominal fat distribution and improves insulin sensitivity. Diabetologia. 2002;45(3):369-77.

212. Serhan CN. Lipoxins and aspirin-triggered 15-epi-lipoxins are the first lipid mediators of endogenous anti-inflammation and resolution. Prostaglandins Leukot Essent Fatty Acids. 2005;73(3-4):141-62.

213. Node K, Huo Y, Ruan X, Yang B, Spiecker M, Ley K, et al. Anti-inflammatory properties of cytochrome P450 epoxygenase-derived eicosanoids. Science. 1999;285(5431):1276-9.

214. Petersson H, Basu S, Cederholm T, Risérus U. Serum fatty acid composition and indices of stearoyl-CoA desaturase activity are associated with systemic inflammation: longitudinal analyses in middle-aged men. Br J Nutr. 2008:99(6):1186-9.

215. Petersson H, Lind L, Hulthe J, Elmgren A, Cederholm T, Risérus U. Relationships between serum fatty acid composition and multiple markers of inflammation and endothelial function in an elderly population. Atherosclerosis. 2009;203(1):298-303.

216. Harris WS, Poston WC, Haddock CK. Tissue $n-3$ and $n-6$ fatty acids and risk for coronary heart disease events. Atherosclerosis. 2007;193(1):1-10.

217. Miettinen M, Turpeinen O, Karvonen MJ, Pekkarinen M, Paavilainen E, Elosuo R. Dietary prevention of coronary heart disease in women: the Finnish mental hospital study. Int J Epidemiol. 1983;12(1):17-25.

218. Frantz ID Jr, Dawson EA, Ashman PL, Gatewood LC, Bartsch GE, Kuba K, et al. Test of effect of lipid lowering by diet on cardiovascular risk: the Minnesota Coronary Survey. Arteriosclerosis. 1989;9(1):129-35.

219. Kris-Etherton P, Fleming J, Harris WS. The debate about n-6 polyunsaturated fatty acid recommendations for cardiovascular health. J Am Diet Assoc. 2010;110(2):201-4

220. Lloyd-Williams F, O'Flaherty M, Mwatsama M, Birt C, Ireland R, Capewell S, Estimating the cardiovascular mortality burden attributable to the European Common Agricultural Policy on dietary saturated fats. Bull World Health Organ. 2008;86(7):535-41A.

221. Ramsden CE, Hibbeln JR, Majchrzak SF, Davis JM. n-6 fatty acid-specific and mixed polyunsaturate dietary interventions have different effects on $\mathrm{CHD}$ risk: a meta-analysis of randomised controlled trials. Br J Nutr. 2010;104(11):1586-600.

222. Simopoulos AP. The importance of the ratio of omega-6/ omega-3 essential fatty acids. Biomed Pharmacother. 2002;56(8):365-79.

223. Simopoulos AP. Evolutionary aspects of diet, the omega-6/ omega-3 ratio and genetic variation: nutritional implications for chronic diseases. Biomed Pharmacother. 2006;60(9):502-7.

224. Gómez Candela C, Bermejo López LM, Loria Kohen V. Importance of a balanced omega 6/omega 3 ratio for the maintenance of health: nutritional recommendations. Nutr Hosp. 2011;26(2):323-9.

225. de Lorgeril M, Renaud S, Mamelle N, Salen P, Martin JL, Monjaud I, et al Mediterranean alpha-linolenic acid-rich diet in secondary prevention of coronary heart disease. Lancet. 1994;343(8911):1454-9.

226. Harris WS. The omega-6/omega-3 ratio and cardiovascular disease risk: uses and abuses. Curr Atheroscler Rep. 2006;8(6):453-9. 
227. Griffin BA. How relevant is the ratio of dietary $n-6$ to $n-3$ polyunsaturated fatty acids to cardiovascular disease risk? Evidence from the OPTILIP study. Curr Opin Lipidol. 2008;19(1):57-62.

228. Liou YA, King DJ, Zibrik D, Innis SM. Decreasing linoleic acid with constant alpha-linolenic acid in dietary fats increases ( $\mathrm{n}-3$ ) eicosapentaenoic acid in plasma phospholipids in healthy men. J Nutr. 2007;137(4):945-52.

229. Brouwer IA, Wanders AJ, Katan MB. Effect of animal and industrial trans fatty acids on HDL and LDL cholesterol levels in humans--a quantitative review. PLoS One. 2010;5(3):e9434.

230. Ascherio A, Katan MB, Zock PL, Stampfer MJ, Willett WC. Trans fatty acids and coronary heart disease. N Engl J Med. 1999;340(25):1994-8.

231. Mozaffarian D, Katan MB, Ascherio A, Stampfer MJ, Willett WC. Trans fatty acids and cardiovascular disease. N Engl J Med. 2006;354(15):1601-13.

232. Mensink RP, Katan MB. Effect of dietary trans fatty acids on high-density and low-density lipoprotein cholesterol levels in healthy subjects. N Engl J Med. 1990;323(7):439-45

233. Mozaffarian D, Aro A, WillettWC. Health effectstrans-fatty acids: experimental and observational evidence. Eur J Clin Nutr. 2009;63(Suppl 2):S5-21.

234. Niu SL, Mitchell DC, Litman BJ. Trans fatty acid derived phospholipids show increased membrane cholesterol and reduced receptor activation as compared to their cis analogs. Biochemistry. 2005;44(11):4458-65.

235. Matthan NR, Welty FK, Barrett PH, Harausz C, Dolnikowski GG, Parks JS, et al. Dietary hydrogenated fat increases high-density lipoprotein apoA-I catabolism and decreases low-density lipoprotein apoB-100 catabolism in in hypercholesterolemic women. Arterioscler Thromb Vasc Biol. 2004;24(6):1092-7.

236. Willett WC. The scientific basis for TFA regulations-is it sufficient? Comments from the USA. Atheroscler Suppl. 2006;7(2):69-71.

237. Matthan NR, Ausman LM, Lichtenstein AH, Jones PJ. Hydrogenated fat consumption affects cholesterol synthesis in moderately hypercholesterolemic women. J Lipid Res. 2000;41(5):834-9.

238. Machado RM, Stefano JT, Oliveira CP, Mello ES, Ferreira FD, Nunes VS, et al. Intake of trans fatty acids causes nonalcoholic steatohepatitis and reduces adipose tis- sue fat content. J Nutr. 2010;140(6):1127-32.

239. Vergès B. Lipid modification in type 2 diabetes: the role of LDL and HDL. Fundam Clin Pharmacol. 2009;23(6):681-5.

240. Buonacorso V, Nakandakare ER, Nunes VS, Passarelli M, Quintão EC, Lottenberg AM. Macrophage cholesterol efflux elicited by human total plasma and by HDL subfractions is not affec- ted by different types of dietary fatty acids. Am J Clin Nutr. 2007;86(5):1270-7.

241. Cassagno N, Palos-Pinto A, Costet P, Breilh D, Darmon M, Berard AM. Low amounts of trans 18:1 fatty acids elevate plasma triacylglycerols but not cholesterol and alter the cellular defense to oxidative stress in mice. Br J Nutr. 2005;94(3):346-52.

242. Mauger JF, Lichtenstein AH, Ausman LM, Jalbert SM, Jauhiainen M, Ehnholm C, et al. Effect of different forms of dietary hydrogenated fats on LDL particle size. Am J Clin Nutr. 2003;78(3):370-5.

243. Ibrahim A, Natrajan S, Ghafoorunissa R. Dietary trans-fatty acids alter adipocyte plasma membrane fatty acid composition and insulin sensitivity in rats. Metabolism. 2005;54(2):240-6.

244. Bendsen NT, Haugaard SB, Larsen TM, Chabanova E, Stender S, Astrup A. Effect of trans fatty acid intake on insulin sensitivity and intramuscular lipids-a randomized trial in overweight postmenopausal women. Metabolism. 2011;60(7):906-13.

245. Tetri LH, Basaranoglu M, Brunt EM, Yerian LM, Neuschwander-Tetri BA. Severe NAFLD with hepatic necro inflammatory changes in mice fed trans fats and a high-fructose corn syrup equivalent. Am J Physiol Gastrointest Liver Physiol. 2008;295(5):G987-95.

246. Teegala SM, Willett WC, Mozaffarian D. Consumption and health effects of trans fatty acids: a review. J AOAC Int. 2009;92(5):1250-7.
247. Baer DJ, Judd JT, Clevidence BA, Tracy RP. Dietary fatty acids affect plasma markers of inflammation in healthy men fed controlled diets: a randomized crossover study. Am J Clin Nutr. 2004;79(6):969-73.

248. Lichtenstein AH, Erkkila AT, Lamarche B, Schwab US, Jalbert SM, Ausman LM. Influence of hydrogenated fat and butter on CVD risk factors: remnantlike particles, glucose and insulin, blood pressure and C-reactive protein. Atherosclerosis. 2003;171(1):97-107.

249. Smit LA, Katan MB, Wanders AJ, Basu S, Brouwer IA. A high intake of transfatty acids has little effect on markers of inflammation and oxidative stress in humans. J Nutr. 2011;141(9):1673-8.

250. Bassett CM, Mc Cullough RS, Edel AL, Maddaford TG, Dibrov E, Blackwood DP, et al. Trans-fatty acids in the diet stimulate atherosclerosis. Metabolism. 2009;58(12):1802-8.

251.Zapolska-Downar D, Kosmider A, Naruszewicz M. Trans fatty acids induce apoptosis in human endothelial cells. J Physiol Pharmacol. 2005;56(4):611-25.

252. McKeigue P. Trans fatty acids and coronary heart disease: weighing the evidence against hardened fat. Lancet. 1995;345(8945):269-70.

253.Sun Q, Ma J, Campos H, Hu FB. Plasma and erythrocyte biomarkers of dairy fat intake and risk of ischemic heart disease. Am J Clin Nutr. 2007;86(4):929-37.

254.de Roos NM, Bots ML, Katan MB. Replacement of dietary saturated fatty acids by trans fatty acids lowers serum HDL cholesterol and impairs endothelial function in healthy men and women. Arterioscler Thromb Vasc Biol. 2001;21(7):1233-7.

255. Ascherio A, Rimm EB, Giovannucci EL, Spiegelman D, Stampfer M, Willett WC. Dietary fat and risk of coronary heart disease in men: cohort follow up study in the United States. BMJ. 1996;313(7049):84-90.

256. Aro A, Kardinaal AFM, Salminen I, Kark JD, Riemersma RA, DelgadoRodriguez $\mathrm{M}$, et al. Adipose tissue isomeric trans fatty acids and risk of myocardial infarction in nine countries: the EURAMIC study. Lancet. 1995;345(8945):273-8.

257. Hu FB, Stampfer MJ, Manson JE, Rimm E, Colditz GA, Rosner BA, et al. Dietary fat intake and the risk of coronary heart disease in women. $\mathrm{N}$ Engl J Med. 1997;337(21):1491-9.

258. Mozzaffarian D, Willett WC. Trans fatty acids and cardiovascular risk: a unique cardiometabolic imprint? Curr Atheroscler Rep. 2007;9(6):486-93.

259. Ministério da Saúde. Agência Nacional de Vigilância Sanitária (ANVISA). Resolução-RDC (N.360, de 23 de dezembro de 2003. Diário Oficial da União(DOU);2003;Brasília, 26 dezembro, 2003.[Citado em 2010 mar 23]. Disponível em: http://e-legis.anvisa.gov.br/leisref/public/showAct. php?id $=9059$.

260. Eckel RH, Borra S, Lichtenstein AH, Yin-Piazza SY; Trans Fat Conference Planning Group. Understanding the complexity of trans fatty acid reduction in the American Diet: American Heart Association Trans Fat Conference 2006: report of the Trans Fat Conference Planning Group. Circulation. 2007;115(16):2231-46.

261. Ohara N, Naito Y, Kasama K, Shindo T, Yoshida H, Nagata T, Okuyama H. Similar changes in clinical and pathological parameters in Wistar Kyoto rats after a 13-week dietary intake of canola oil or a fatty acid composition-based interesterified canola oil mimic. Food ChemToxicol. 2009;47(1):157-62.

262. Reena MB, Lokesh BR. Hypolipidemic effect of oils with balanced amounts of fatty acids obtained by blending and interesterification of coconut oil with rice bran oil or sesame oil. J Agric Food Chem. 2007;55(25):10461-9.

263. Reena MB, Gowda LR, Lokesh BR. Enhanced hypocholesterolemic effects of interesterified oils are mediated by upregulating LDL receptor andcholesterol 7-alpha-hydroxylase gene expression in rats. J Nutr. 2011;141(1):24-30.

264. Sundram K, Karupaiah T, Hayes KC. Stearic acid-rich interesterified fat and trans-rich fat raise the $\mathrm{LDL} / \mathrm{HDL}$ ratio and plasma glucose relative to palm olein in humans. Nutr Metab (Lond). 2007;4:3. 
265. Nestel PJ, Noakes M, Belling GB, McArthur R, Clifton PM. Effect on plasma lipids of interesterifying a mix edible oils. Am J Clin Nutr. 1995;62(5):950-5.

266. Wang CH, Kuksis A, Manganaro F. Studies of the substrate specificity of purified human milk lipoprotein lipase. Lipids. 1982;17(4):278-84.

267. Hayes KC. Synthetic and modified glycerides: effects on plasma lipids. Curr Opin Lipidol. 2001;12(1):55-60.

268. Yli-Jokipii K, Kallio H, Schwab U, Mykkanen H, Kurvinen JP, Savolainen MJ, et al. Effects of palm oil and transesterified palm oil on chylomicron and VLDL triacylglycerol structures and postprandial lipid response. J Lipid Res. 2001;42(10):1618-25

269. Robinson DM, Martin NC, Robinson LE, Ahmadi L, Marangoni AG, Wright AJ. Influence of interesterification of a stearic acid-rich spreadable fat on acute metabolic risk factos. Lipids. 2009;44(1):17-26.

270. Meijer GW, Westrate JA. Interesterification of fats in margarine: effect on blood lipids, blood enzymes, and hemostasis parameters. Eur J Clin Nutr. 1997;51(8):527-34.

271. Vos E, Cunnane SC, Lanzmann-Petithory D. n-3 fatty acids and cardiovascular events. N Engl J Med. 2011;364(9):880-1.

272. de Koning L, Chiuve SE, Fung TT, Willett WC, Rimm EB, Hu FB. Dietquality scores and the risk of type 2 diabetes in men. Diabetes Care. 2011;34(5):1150-6.

273. Jakobsen MU, Overvad K. Macronutrient advice for ischemic heart disease prevention. Curr Opin Lipidol. 2011;22(1):33-6.

274. Wang S, Hwang H, Yoon S, Choe E. Temperature dependence of autoxidation of perilla oil and tocopherol degradation. J Food Sci. 2010;75(6):C498-505.

275. Choe E, Min DB. Chemistry of deep-fat frying oils. J Food Sci. 2007;72(5):R77-86.

276. Spiteller G. The relation of lipid peroxidation processes with atherogenesis: a new theory on atherogenesis. Mol Nutr Food Res. 2005; 49(11):999-1013.

277. Valenzuela A, Morgado N. Trans fatty acid isomers in human health and in the food industry. Biol Res. 1999; 32(4):273-87.

278. Misra A, Sharma R, Gulati S, Joshi SR, Sharma V, Ghafoorunissa, et al.; For The National Dietary Guidelines Consensus Group. Consensus dietary guidelines for healthy living and prevention of obesity, the metabolic syndrome, diabetes, and related disorders in Asian Indians. Diabetes Technol Ther. 2011;13(6):683-94.

279. Mozaffarian D, Jacobson MF, Greenstein JS. Food reformulations to reduce trans fatty acids. N Engl J Med. 2010;362(21):2037-9.

280. Thompson AK, Minihane AM, Williams CM. Trans fatty acids, insulin resistance and diabetes. Eur J Clin Nutr. 2011;65(5):553-64.

281. Thompson AK, Minihane AM, Williams CM. Trans fatty acids and weight gain. Int J Obes (Lond). 2011;35(3):315-24.

282. Kendall CW, Josse AR, Esfahani A, Jenkins DJ. Nuts, metabolic syndrome and diabetes. Br J Nutr. 2010;104(4):465-73.

283. Ortega RM. Importance of functional foods in the Mediterranean diet. Public Health Nutr. 2006;9(8A):1136-40.

284. Basu S. Fatty acid oxidation and isoprostanes: oxidative strain and oxidative stress. Prostaglandins Leukot Essent Fatty Acids. 2010;82(4-6):219-25.

285. Silva FAM, Borges MFM, Ferreira MA. Métodos para avaliação do grau de oxidação lipídica e da capacidade antioxidante. Química Nova. 1999;22(1):94-103.

286. Kalua CM, Bedgood DR Jr, Bishop AG, Prenzler PD. Discrimination of storage conditions and freshness in virgin olive oil. J Agric Food Chem. 2006;54(19):7144-51.

287. Riediger ND, Othman R, Fitz E, Pierce GN, Suh M, Moghadasian MH. Low n-6:n-3 fatty acid ratio, with fish- or flaxseed oil, in a high fat diet improves plasma lipids and beneficially alters tissue fatty acid composition in mice. Eur J Nutr. 2008:47(3):153-60.
288. Cintra DE, Costa AV, Peluzio MC, Matta SL, Silva MT, Costa NM. Lipid profile of rats fed high-fat diets based on flaxseed, peanut, trout, or chicken skin. Nutrition. 2006;22(2):197-205.

289. Sugamura K, Keaney JF Jr. Reactive oxygen species in cardiovascular disease Free Radic Biol Med. 2011;51(5):978-92.

290. Yamashita K, Ikeda S, Obayashi M. Comparative effects of flaxseed and sesame seed on vitamin $\mathrm{E}$ and cholesterol levels in rats. Lipids. $2003 ; 38(12): 1249-55$.

291. López-Uriarte P, Bulló M, Casas-Agustench P, Babio N, Salas-Salvadó J. Nuts and oxidation: a systematic review. Nutr Rev. 2009;67(9):497-508.

292. Liu WH, Lu YF, Inbaraj BS, Chen BH. Formation of trans fatty acids in chicken legs during frying. Int J Food Sci Nutr. 2008;59(5):368-82.

293. Tarmizi AH, Lin SW. Quality assessment of palm products upon prolonged heat treatment. J Oleo Sci. 2008;57(12):639-48.

294. Attya M, Benabdelkamel H, Perri E, Russo A, Sindona G. Effects of conventional heating on the stability of major olive oil phenolic compounds by tandem mass spectrometry and isotope dilution assay. Molecules. 2010;15(12):8734-46.

295. Casal S, Malheiro R, Sendas A, Oliveira BP, Pereira JA. Olive oil stability under deep-frying conditions. Food Chem Toxicol. 2010;48(10):2972-9.

296. Osório VM, de Lourdes Cardeal Z. Determination of acrolein in french fries by solid-phase microextraction gas chromatography and mass spectrometry. J Chromatogr A. 2011;1218(21):3332-6.

297. Ministério do Desenvolvimento, Indústria e Comércio Exterior. Instituto Nacional de Metrologia, Normalização e Qualidade Industrial (INMETRO). Programa de Análise de Produtos: Relatório sobre Análise de Gordura e Colesterol em Azeite de Oliva e de Dendê. 2010, 1-19.

298. Le HD, Meisel JA, de Meijer VE, Gura KM, Puder M. The essentiality of arachidonic acid and docosahexaenoic acid. Prostaglandins Leukot Essent Fatty Acids. 2009;81(2-3):165-70.

299. Ueda Y, Kawakami Y, Kunii D, Okada H, Azuma M, Le DS, et al. Elevated concentrations of linoleic acid in erythrocyte membrane phospholipids in patients with inflammatory bowel disease. Nutr Res. 2008;28(4):239-44.

300. Weaver KL, Ivester P, Seeds M, Case LD, Arm JP, Chilton FH. Effect of dietary fatty acids on inflammatory gene expression in healthy humans. J Biol Chem. 2009;284(23):15400-7.

301. Margioris AN. Fatty acids and postprandial inflammation. Curr Opin Clin Nutr Metab Care. 2009;12(2):129-37.

302. Lumeng CN, Saltiel AR. Inflammatory links between obesity and metabolic disease. J Clin Invest. 2011;121(6):2111-7.

303. Fresno M, Alvarez R, Cuesta N. Toll-like receptors, inflammation, metabolism and obesity. Arch Physiol Biochem. 2011;117(3):151-64.

304. Powell K. Obesity: the two faces of fat. Nature. 2007;447(7144):525-7.

305. Hotamisligil GS. Inflammation and metabolic disorders. Nature. 2006;444(7121):860-7

306. Simopoulos AP. The importance of the omega-6/omega-3 fatty acid ratio in cardiovascular disease and other chronic diseases. Exp Biol Med (Maywood). 2008;233(6):674-88

307. Bensinger SJ, Tontonoz P. Integration of metabolism and inflammation by lipid-activated nuclear receptors. Nature. 2008;454(7203):470-7.

308. Van Gaal LF, Mertens IL, De Block CE. Mechanisms linking obesity with cardiovascular disease. Nature. 2006;444(7121):875-80.

309. Libby P. Inflammation in atherosclerosis. Nature. 2002;420(6917):868-74

310. Gopinath B, Buyken AE, Flood VM, Empson M, Rochtchina E, Mitchell P. Consumption of polyunsaturated fatty acids, fish, and nuts and risk of inflammatory disease mortality. Am J Clin Nutr. 2011;93(5):1073-9.

311. Ros E, Mataix J. Fatty acid composition of nuts-implications for cardiovascular health. Br J Nutr. 2006;96(Suppl 2):S29-35. 
312. Williams CM, Burdge G. Long-chain n-3 PUFA: plant vs. marine sources. Proc Nutr Soc. 2006;65(1):42-50.

313. Morise A, Combe N, Boué C, Legrand P, Catheline D, Delplanque B, et al. Dose effect of alpha-linolenic acid on PUFA conversion, bioavailability, and storage in the hamster. Lipids. 2004;39(4):325-34.

314. Caballeroa MJ, Obachb A, Rosenlundb G, Monteroa D, Gisvoldb M, Izquierdoa MS. Impact of different dietary lipid sources on growth, lipid digestibility, tissue fatty acid composition and histology of rainbow trout (Oncorhynchus mykiss). Aquaculture. 2002;214(1-4):253-71.

315. Dyerberg J, Bang HO. Haemostatic function and platelet polyunsaturated fatty acids in Eskimos. Lancet. 1979;2(8140):433-5.

316. Kromhout $\mathrm{D}$, Bosschieter EB, de Lezenne Coulander $\mathrm{C}$. The inverse relation between fish consumption and 20-year mortality from coronary heart disease. N Engl J Med. 1985;312(19):1205-9.

317. Fish consumption and mortality from coronary heart disease. N Engl J Med. 1985;313(13):820-4

318. Ascherio A, Rimm EB, Stampfer MJ, Giovannucci EL, Willett WC. Dietary intake of marine $\mathrm{n}-3$ fatty acids, fish intake, and the risk of coronary disease among men. N Engl J Med. 1995;332(15):977-82.

319. Daviglus ML, Stamler J, Orencia AJ, Dyer AR, Liu K, Greenland P, et al. Fish consumption and the 30-year risk of fatal myocardial infarction. N Engl J Med. 1997;336(15):1046-53.

320. Daniel CR, Cross AJ, Graubard BI, Hollenbeck AR, Park Y, Sinha R. Prospective investigation of poultry and fish intake in relation to cancer risk. Cancer Prev Res (Phila). 2011;4(11):1903-11.

321. Universidade de São Paulo. Faculdade de Ciências Farmacêuticas. Departamento de Alimentos e Nutrição Experimental/BRASILFOODS (1998). Tabela Brasileira de Composição de Alimentos-USP. Versão 5.0.[Citado em 2011 out 20] Disponível em: http://www.fcf.usp.br/ tabela.

322. Megdal PA, Craft NA, Handelman GJ. A simplified method to distinguish farmed (Salmo salar) from wild salmon: fatty acid ratios versus astaxanthin chiral isomers. Lipids. 2009;44(6):569-76.

323. Li G, Sinclair AJ, Li D. Comparison of lipid content and Fatty Acid composition in the edible meat of wild and cultured freshwater and marine fish and shrimps from china. J Agric Food Chem. 2011;59(5):1871-81.

324. Huynh MD, Kitts DD, Hu C, Trites AW. Comparison of fatty acid profiles of spawning and non-spawning Pacific herring, Clupea harengus pallasi. Comp Biochem Physiol B Biochem Mol Biol. 2007;146(4):504-11.
325. Bell JG, McEvoy J, Tocher DR, McGhee F, Campbell PJ, Sargent JR. Replacement of fish oil with rapeseed oil in diets of Atlantic salmon (Salmo salar) affects tissue lipid compositions and hepatocyte fatty acid metabolism. J Nutr. 2001;131(5):1535-43.

326. Somero GN, DeVries AL. Temperature tolerance of some Antarctic fishes. Science. 1967;156(3772):257-8.

327. SatuéMT, López MC. Sex-linked differences in fatty acid composition of rainbow trout (Oncorynchus mykiss) liver oil. Food Chem. 1996;57(3):359-63.

328. Morais S, Pratoomyot J, Taggart JB, Bron JE, Guy DR, Bell JG, et al. Genotypespecific responses in Atlantic salmon (Salmo salar) subject to dietary fish oil replacement by vegetable oil: a liver transcriptomic analysis. BMC Genomics. 2011;12:255.

329. Bell MV, Dick JR, Porter AE. Biosynthesis and tissue deposition of docosahexaenoic acid (22:6n-3) in rainbow trout (Oncorhynchus mykiss). Lipids. 2001;36(10):1153-9.

330. Ribeiro CS, Gomes AD, Vieira VARO, Tabata YA, Takahashi NS, Moreira RG. The effect of ploidy on the fatty acid profile during the reproductive cycle of female rainbow trout (Oncorhynchus mykiss). Aquaculture Int.2011;Aug 13:1-21.[Citado em 2011 out 24].Disponível em:http://www.springerlink. com/content/488573k62475112x/fulltext.pdf

331. Visentainer JV, Carvalho PO, Ikegaki M, Park YK. Concentração de ácido eicosapentaenóico (EPA) e ácido docosahexaenóico (DHA) em peixes marinhos da costa brasileira. Ciênc Tecnol Aliment. 2000;20(1):90-3.

332. Leaver MJ, Taggart JB, Villeneuve L, Bron JE, Guy DR, Bishop SC, et al. Heritability and mechanisms of $\mathrm{n}-3$ long chain polyunsaturated fatty acid deposition in the flesh of Atlantic salmon. Comp Biochem Physiol Part D Genomics Proteomics. 2011;6(1):62-9.

333. Kennedy SR, Campbell PJ, Porter A, Tocher DR. Influence of dietary conjugated linoleic acid (CLA) on lipid and fatty acid composition in liver and flesh of Atlantic salmon (Salmo salar). Comp Biochem Physiol B Biochol Biol. 2005;141(2):168-78.

334. Trattner S, Kamal-Eldin A, Brännäs E, Moazzami A, Zlabek V, Larsson P, et al. Sesamin supplementation increases white muscle docosahexaenoic acid (DHA) levels in rainbow trout (Oncorhynchus mykiss) fed high alphalinolenic acid (ALA) containing vegetable oil: metabolic actions. Lipids. 2008;43(11):989-97.

335. Benzecry EH, Pinheiro AB, Lacerda EM. Tabela para avaliação de consumo alimentar em medidas caseiras. 4a ed. São Paulo: Atheneu; 2000.

336. Elizabeth Stewart Hand and Associates (ESHA Research). The food processor SQL, version 10.5.0. Salem, (Oregon);2008. 